\title{
Statins for children with familial hypercholesterolemia
}

\section{Vuorio, Alpo}

2019

Vuorio , A , Kuoppala , J , Kovanen , P T , Humphries , S E , Tonstad, S , Wiegman , A ,

Drogari , E \& Ramaswami , U 2019 , ' Statins for children with familial hypercholesterolemia '

Cochrane database of systematic reviews , no. 11, CD006401 . https://doi.org/10.1002/14651858.CD006401.pub5

http://hdl.handle.net/10138/330980

https://doi.org/10.1002/14651858.CD006401.pub5

publishedVersion

Downloaded from Helda, University of Helsinki institutional repository.

This is an electronic reprint of the original article.

This reprint may differ from the original in pagination and typographic detail.

Please cite the original version. 


\section{Statins for children with familial hypercholesterolemia (Review)}

Vuorio A, Kuoppala J, Kovanen PT, Humphries SE, Tonstad S, Wiegman A, Drogari E, Ramaswami U

Vuorio A, Kuoppala J, Kovanen PT, Humphries SE, Tonstad S, Wiegman A, Drogari E, Ramaswami U. Statins for children with familial hypercholesterolemia.

Cochrane Database of Systematic Reviews 2019, Issue 11. Art. No.: CD006401.

DOI: 10.1002/14651858.CD006401.pub5.

www.cochranelibrary.com 
TABLE OF CONTENTS

HEADER 1

ABSTRACT

PLAIN LANGUAGE SUMMARY

SUMMARY OF FINDINGS

BACKGROUND

OBJECTIVES

METHODS

RESULTS

Figure 1.

DISCUSSION

AUTHORS' CONCLUSIONS

ACKNOWLEDGEMENTS

REFERENCES

CHARACTERISTICS OF STUDIES

DATA AND ANALYSES

Analysis 1.1. Comparison 1 Statins versus control, Outcome 1 Change in carotid intima-media thickness (mm).

Analysis 1.2. Comparison 1 Statins versus control, Outcome 2 Change in serum LDL cholesterol level (\%).

Analysis 1.3. Comparison 1 Statins versus control, Outcome 3 Change in puberty (Tanner stage $\geqq 1$ level).

Analysis 1.4. Comparison 1 Statins versus control, Outcome 4 Change in aspartate aminotransferase levels (> 3x ULN).

Analysis 1.5. Comparison 1 Statins versus control, Outcome 5 Change in alanine aminotransferase levels (> $3 x$ ULN).

Analysis 1.6. Comparison 1 Statins versus control, Outcome 6 Myopathy: Change in creatine kinase levels (> 10x ULN).

Analysis 1.7. Comparison 1 Statins versus control, Outcome 7 Change in flow-mediated dilatation of brachial artery (\%).

Analysis 1.8. Comparison 1 Statins versus control, Outcome 8 Change in serum total cholesterol levels (\%).

Analysis 1.9. Comparison 1 Statins versus control, Outcome 9 Change in serum HDL cholesterol levels (\%).

Analysis 1.10. Comparison 1 Statins versus control, Outcome 10 Change in serum triglyceride levels (\%).

Analysis 1.11. Comparison 1 Statins versus control, Outcome 11 Adverse events.

APPENDICES

WHAT'S NEW

HISTORY

CONTRIBUTIONS OF AUTHORS

DECLARATIONS OF INTEREST

SOURCES OF SUPPORT

DIFFERENCES BETWEEN PROTOCOL AND REVIEW

INDEX TERMS 
[Intervention Review]

\title{
Statins for children with familial hypercholesterolemia
}

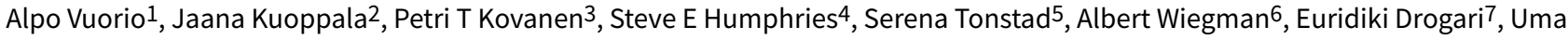 \\ Ramaswami8 \\ 1Department of Forensic Medicine, University of Helsinki, Helsinki, Finland. ${ }^{2}$ University of Helsinki, Helsinki, Finland. ${ }^{3}$ Wihuri Research \\ Institute, Helsinki, Finland. ${ }^{4}$ Center for Cardiovascular Genetics, BHF Laboratories, Royal Free and University College Medical School, \\ London, UK. ${ }^{5}$ Dept. of Preventive Cardiology, Ullevål University Hospital, Olso, Norway. ${ }^{6}$ Department of Pediatrics, Academic Medical \\ Center, Amsterdam, Netherlands. 7 Unit of Metabolic Disorders, First Department of Pediatrics, National and Kapodistrian University of \\ Athens, Medical School, Athens, Greece. 8Lysosomal Unit, Royal Free Hospital, London, UK
}

Contact address: Alpo Vuorio, Department of Forensic Medicine, University of Helsinki, Helsinki, Finland. alpo.vuorio@gmail.com.

Editorial group: Cochrane Cystic Fibrosis and Genetic Disorders Group.

Publication status and date: Edited (no change to conclusions), published in Issue 3, 2020.

Citation: Vuorio A, Kuoppala J, Kovanen PT, Humphries SE, Tonstad S, Wiegman A, Drogari E, Ramaswami U. Statins for children with familial hypercholesterolemia. Cochrane Database of Systematic Reviews 2019, Issue 11. Art. No.: CD006401. DOI: 10.1002/14651858.CD006401.pub5.

Copyright ( 2020 The Cochrane Collaboration. Published by John Wiley \& Sons, Ltd.

\section{A B S T R A C T}

\section{Background}

Familial hypercholesterolemia is one of the most common inherited metabolic diseases and is an autosomal dominant disorder meaning heterozygotes, or carriers, are affected. Those who are homozygous have severe disease. The average worldwide prevalence of heterozygous familial hypercholesterolemia is at least 1 in 500, although recent genetic epidemiological data from Denmark and next generation sequencing data suggest the frequency may be closer to 1 in 250. Diagnosis of familial hypercholesterolemia in children is based on elevated total cholesterol and low-density lipoprotein cholesterol levels or DNA-based analysis, or both. Coronary atherosclerosis has been detected in men with heterozygous familial hypercholesterolemia as young as 17 years old and in women with heterozygous familial hypercholesterolemia at 25 years old. Since the clinical complications of atherosclerosis occur prematurely, especially in men, lifelong treatment, started in childhood, is needed to reduce the risk of cardiovascular disease. In children with the disease, diet was the cornerstone of treatment but the addition of lipid-lowering medications has resulted in a significant improvement in treatment. Anion exchange resins, such as cholestyramine and colestipol, were found to be effective, but they are poorly tolerated. Since the 1990 s studies carried out on children aged 6 to 17 years with heterozygous familial hypercholesterolemia have demonstrated significant reductions in their serum total and low-density lipoprotein cholesterol levels. While statins seem to be safe and well-tolerated in children, their longterm safety in this age group is not firmly established. This is an update of a previously published version of this Cochane Review.

\section{Objectives}

To assess the effectiveness and safety of statins in children with heterozygous familial hypercholesterolemia.

\section{Search methods}

Relevant studies were identified from the Group's Inborn Errors and Metabolism Trials Register and Medline.

Date of most recent search: 04 November 2019.

\section{Selection criteria}

Randomized and controlled clinical studies including participants up to 18 years old, comparing a statin to placebo or to diet alone.

\section{Data collection and analysis}

Two authors independently assessed studies for inclusion and extracted data. 


\section{Main results}

We found 26 potentially eligible studies, of which we included nine randomized placebo-controlled studies (1177 participants). In general, the intervention and follow-up time was short (median 24 weeks; range from six weeks to two years). Statins reduced the mean low-density lipoprotein cholesterol concentration at all time points (high-quality evidence). There may be little or no difference in liver function (serum aspartate and alanine aminotransferase, as well as creatinine kinase concentrations) between treated and placebo groups at any time point (low-quality evidence). There may be little or no difference in myopathy (as measured in change in creatinine levels) (low-quality evidence) or clinical adverse events (moderate-quality evidence) with statins compared to placebo. One study on simvastatin showed that this may slightly improve flow-mediated dilatation of the brachial artery (low-quality evidence), and on pravastatin for two years may have induced a regression in carotid intima media thickness (low-quality evidence).

No studies reported rhabdomyolysis (degeneration of skeletal muscle tissue) or death due to rhabdomyolysis, quality of life or compliance to study medication.

\section{Authors' conclusions}

Statin treatment is an effective lipid-lowering therapy in children with familial hypercholesterolemia. Few or no safety issues were identified. Statin treatment seems to be safe in the short term, but long-term safety remains unknown. Children treated with statins should be carefully monitored and followed up by their pediatricians and their care transferred to an adult lipidologist once they reach 18 years of age. Large long-term randomized controlled trials are needed to establish the long-term safety issues of statins.

\section{PLAIN LANGUAGE SUMMARY}

\section{Statins for children with inherited high blood cholesterol}

\section{Review question}

We reviewed the evidence for the effectiveness and safety of statins in children with inherited high blood cholesterol.

\section{Background}

Familial hypercholesterolemia is an inherited disease in which the blood cholesterol level is high. Vascular disease, i.e. furring up of the blood vessels, often occurs at an earlier age than usual, especially amongst men. Thus lifelong therapies, started in childhood, to reduce blood cholesterol are needed. In children with familial hypercholesterolemia, diet has been the main treatment option. Medications, such as cholestyramine and colestipol, have been used effectively, but due to their unpleasant taste they are poorly tolerated and treatment plans are not followed. The advent of statin therapy for children has improved treatment and this review updates the previous published version.

\section{Search date}

The evidence is current to: 04 November 2019.

\section{Study characteristics}

The review included 9 studies with 1177 people with heterozygous familial hypercholesterolemia aged between 4 and 18 years of age. Studies compared different statin treatments with a substance which contains no medication (termed placebo) and people were selected for one treatment or the other randomly. The studies lasted from 12 weeks to 104 weeks.

\section{Key results}

In general, the intervention and follow-up time was short (median 24 weeks; range from six weeks to two years). Statins probably reduced the mean low-density lipoprotein cholesterol concentration at all time points (high-quality evidence). The levels of the liver enzymes, serum aspartate and alanine aminotransferase, and the muscle enzyme, creatinine kinase, did not differ between treated and placebo groups at any time point (low-quality evidence). The risks of myopathy (disease of muscle tissue) and side-effects were very low and similar in both groups (low-quality evidence). Two of the statins, simvastatin and pravastatin may have a positive effect on two of the major blood vessels typically affected by raised cholesterol levels (low-quality evidence).

\section{Quality of the evidence}

Information regarding blinding (performance bias and detection bias), was available for all nine studies; each was described as double blind, indicating that participants and those participating in treatment procedures were blinded to treatment. In two studies information on how the participants were allocated to treatment groups (selection bias) was clearly presented, but this information was not clearly stated in the remaining seven studies. There is a lack of information whether investigators knew which treatment group participants would be put into (selection bias) and or whether selective reporting (reporting bias) occurred, but it is very unlikely. In conclusion, it can be stated all the studies appeared to be well run and we do not think any of the above-mentioned factors influenced the results in a negative way. Quality of evidence varied from high (change in serum low-density lipoprotein (LDL) cholesterol) through moderate (adverse events) to low 
(change in blood vessel wall (carotid intima-media) thickness, change in measures if growth and maturation, liver dysfunction, myopathy and change in blood wall (endothelial) function). 
SUMMARY OF FINDINGS

Summary of findings for the main comparison.

Statins compared with placebo for children with familial hypercholesterolemia

Patient or population: children with familial hypercholesterolemia

Settings: outpatients

Intervention: statins

Comparison: placebo

\begin{tabular}{|c|c|c|c|c|c|c|}
\hline \multirow[t]{3}{*}{ Outcomes } & \multicolumn{2}{|c|}{ Illustrative comparative risks* $(95 \% \mathrm{Cl})$} & \multirow{3}{*}{$\begin{array}{l}\text { Relative } \\
\text { effect } \\
\text { (95\% } \\
\text { CI) }\end{array}$} & \multirow{3}{*}{$\begin{array}{l}\text { No of } \\
\text { Partici- } \\
\text { pants } \\
\text { (stud- } \\
\text { ies) }\end{array}$} & \multirow{3}{*}{$\begin{array}{l}\text { Qual- } \\
\text { ity of } \\
\text { the evi- } \\
\text { dence } \\
\text { (GRADE) }\end{array}$} & \multirow[t]{3}{*}{ Comments } \\
\hline & Assumed risk & Corresponding risk & & & & \\
\hline & Placebo & Statins & & & & \\
\hline $\begin{array}{l}\text { Change in carotid inti- } \\
\text { ma-media thickness ( } \mathbf{m m}) \text { - } \\
\text { at } 2 \text { years } \\
\text { Follow-up: } 2 \text { years }\end{array}$ & $\begin{array}{l}\text { The mean change in } \\
\text { carotid intima-media } \\
\text { thickness was } 0.005 \mathrm{~mm} \\
\text { in the placebo group. }\end{array}$ & $\begin{array}{l}\text { The mean change in carotid } \\
\text { intima-media thickness was } \\
0.01 \mathrm{~mm} \text { lower }(0.03 \mathrm{~mm} \text { low- } \\
\text { er to } 0.00 \mathrm{~mm} \text { lower) in the } \\
\text { stains group. }\end{array}$ & NA & $\begin{array}{l}211 \\
\text { (1 study) }\end{array}$ & $\begin{array}{l}\oplus \oplus \ominus \ominus \\
\text { low } \mathbf{1 , 4}\end{array}$ & \\
\hline $\begin{array}{l}\text { Change in serum LDL choles- } \\
\text { terol level (\%) - at end of fol- } \\
\text { low-up } \\
\text { Follow-up: up to } 48 \text { weeks }\end{array}$ & $\begin{array}{l}\text { The mean change in } \\
\text { serum LDL cholesterol } \\
\text { level ranged from a } 5 \% \\
\text { increase to a } 4 \% \text { de- } \\
\text { crease across placebo } \\
\text { groups. }\end{array}$ & $\begin{array}{l}\text { The mean change in serum } \\
\text { LDL cholesterol level was } \\
32.15 \% \text { lower ( } 34.90 \% \text { lower } \\
\text { to } 29.40 \% \text { lower) in the stains } \\
\text { group. }\end{array}$ & NA & $\begin{array}{l}669 \\
\text { (6 stud- } \\
\text { ies) }\end{array}$ & $\begin{array}{l}\oplus \oplus \oplus \oplus \\
\text { high }\end{array}$ & $\begin{array}{l}\text { Even with some concerns regarding risk } \\
\text { of bias and heterogeneity, given the ef- } \\
\text { fect size, we regard this as high-quality } \\
\text { evidence } \\
\text { Heterogeneity: } I^{2}=89 \% \\
\text { This outcome was also reported at at } 1 \\
\text { month ( } 228 \text { participants, } 3 \text { studies), } 6 \\
\text { months ( } 528 \text { participants, } 4 \text { studies) and } \\
\text { at } 1 \text { year ( } 254 \text { participants, } 2 \text { studies). All } \\
\text { pooled results were in favour of statins; } \\
\text { the latter two analyses were also very } \\
\text { heterogeneous }\left(I^{2}>85 \%\right)\end{array}$ \\
\hline $\begin{array}{l}\text { Change in measures of } \\
\text { growth and maturation: } \\
\text { change in puberty propor- } \\
\text { tion with Tanner stage } \geqq 1 \\
\text { level - at } 2 \text { years }\end{array}$ & 636 per 1000 & $\begin{array}{l}\mathbf{6 0 4} \text { per } 1000 \\
\text { (489 to } 750 \text { per } 1000)\end{array}$ & $\begin{array}{l}\text { RR } 0.95 \\
(95 \% \mathrm{Cl} \\
0.77 \text { to } \\
1.18)\end{array}$ & $\begin{array}{l}211 \\
\text { (1 study) }\end{array}$ & $\begin{array}{l}\oplus \oplus \ominus \ominus \\
\text { low } \mathbf{1 , 2}\end{array}$ & $\begin{array}{l}\text { This outcome was also reported at at } 6 \\
\text { months ( } 355 \text { participants, } 2 \text { studies) and } \\
\text { at } 1 \text { year ( } 139 \text { participants, } 1 \text { study). }\end{array}$ \\
\hline
\end{tabular}




\begin{tabular}{|c|c|c|c|c|c|c|}
\hline $\begin{array}{l}\text { Liver dysfunction: propor- } \\
\text { tion with changed aspartate } \\
\text { aminotransferase or alanine } \\
\text { aminotransferase levels (> } \\
3 \times \text { ULN) - at all time points } \\
\text { Follow-up: up to } 2 \text { years }\end{array}$ & $\begin{array}{l}\text { There were } 2 \text { cases } \\
\text { of changed aspartate } \\
\text { aminotransferase lev- } \\
\text { els and no cases of } \\
\text { changed alanine amino- } \\
\text { transferase levels in the } \\
\text { placebo groups (at all } \\
\text { time points). }\end{array}$ & $\begin{array}{l}\text { There were } 4 \text { cases of } \\
\text { changed aspartate amino- } \\
\text { transferase levels and four } \\
\text { cases of changed alanine } \\
\text { aminotransferase levels in } \\
\text { the statins groups (at all time } \\
\text { points). }\end{array}$ & $\begin{array}{l}\text { See } \\
\text { com- } \\
\text { ment }\end{array}$ & $\begin{array}{l}\text { up to } \\
9244 \\
\text { ( } 7 \text { stud- } \\
\text { ies) }\end{array}$ & $\begin{array}{l}\oplus \oplus \ominus \ominus \\
\text { low } \mathbf{1 , 4}\end{array}$ & $\begin{array}{l}\text { There were no significant differences be- } \\
\text { tween the number of cases at any time } \\
\text { point for either measurement and con- } \\
\text { fidence intervals of pooled results were } \\
\text { wide due to very low numbers of events. }\end{array}$ \\
\hline $\begin{array}{l}\text { Myopathy: proportion with } \\
\text { changed serum creatine ki- } \\
\text { nase levels (>10x ULN) - at } \\
\text { all time points }\end{array}$ & $\begin{array}{l}\text { There were } 2 \text { cases of } \\
\text { changed serum crea- } \\
\text { tine kinase levels in the } \\
\text { placebo groups (at all } \\
\text { time points). }\end{array}$ & $\begin{array}{l}\text { There were } 5 \text { cases of } \\
\text { changed serum creatine ki- } \\
\text { nase levels in the placebo } \\
\text { groups (at all time points). }\end{array}$ & $\begin{array}{l}\text { See } \\
\text { com- } \\
\text { ment }\end{array}$ & $\begin{array}{l}\text { up to } \\
6694 \\
\text { ( } 6 \text { stud- } \\
\text { ies) }\end{array}$ & $\begin{array}{l}\oplus \oplus \ominus \ominus \\
\text { low } \mathbf{1 , 4}\end{array}$ & $\begin{array}{l}\text { There were no significant differences be- } \\
\text { tween the number of cases at any time } \\
\text { point and confidence intervals of pooled } \\
\text { results were wide due to very low num- } \\
\text { bers of events. }\end{array}$ \\
\hline
\end{tabular}

Change in endothelial func-

tion: Change in flow-medi-

ated dilatation of brachial

The mean change in

The mean change in flow-me-

NA

50

$\oplus \oplus \ominus \ominus \mathrm{C}$

flow-mediated dilata-

diated dilatation of brachial

tion of brachial artery

artery was $2.70 \%$ higher

was $1.2 \%$ in the placebo $\quad(0.42 \%$ to $4.98 \%$ higher $)$ in the

(1 study)

low 1

artery (\%)

statins group.

Follow-up: up to 1 year

group.

\section{2 per 1000}

Adverse events - at one year

399 per 1000

(323 to 502 per 1000 )

RR 1.01

276

$(95 \% \mathrm{Cl}$

0.81 to

(2 stud-

ies)

$\oplus \oplus \oplus \odot$

This outcome was also reported at at 1 $1.26)$ at 6 months (416 participants, 3 studies).

Results of analysis at all time points showed no significant differences between statins and placebo.

*The basis for the assumed risk (e.g. the median control group risk across studies) is provided in footnotes. The corresponding risk (and its $95 \%$ confidence interval) is based on the assumed risk in the comparison group and the relative effect of the intervention (and its $95 \% \mathrm{Cl}$ ).

CI: confidence interval; NA: not applicable; RR: risk ratio; ULN: upper limit of normal

GRADE Working Group grades of evidence

High quality: further research is very unlikely to change our confidence in the estimate of effect.

Moderate quality: further research is likely to have an important impact on our confidence in the estimate of effect and may change the estimate.

Low quality: further research is very likely to have an important impact on our confidence in the estimate of effect and is likely to change the estimate.

Very low quality: we are very uncertain about the estimate. 
1. Downgraded once due to unclear risk of bias: methods of allocation concealment not described for any included studies and method of randomization not described for more than half of the included studies.

2. Downgraded once due to applicability: unclear whether changes in puberty are due to a treatment effect of the statins or due to natural changes in puberty of the age group.

3. Some studies contributed data to more than one time point, participants only counted once at the first time point reported.

4. Downgraded once due to imprecision: wide confidence intervals of pooled effects due to very low numbers of events. 


\section{B A C K G R O U N D}

\section{Description of the condition}

Familial hypercholesterolemia (FH) is one of the most common inherited metabolic diseases and, as an autosomal dominant condition, may be either homozygous or heterozygous. Homozygous $\mathrm{FH}$ is the more severe form with a prevalence of at least one case in a million but will not be considered in this review. The average worldwide prevalence of heterozygous $\mathrm{FH}$ individuals has been estimated to be at least about 1 in 500 individuals (Goldstein 1995; Nordestgaard 2013), although recent genetic epidemiological data from Denmark and next generation sequencing data suggest the frequency may be closer to 1 in 250 (Sjouke 2015; Benn 2016; Khera 2016; Pang 2016; Wald 2016). Mutations in one of three genes that encode proteins involved in clearance of low-density lipoprotein (LDL) cholesterol from the blood are known to cause $\mathrm{FH}$. The most common mutations in $\mathrm{FH}$ diminish the number of cellular LDL receptors $(L D L R)$ and render their function defective. This results in a lifelong elevation of serum LDL cholesterol which is two- to three-fold higher among FH heterozygotes than among non-FH people. the other two known causative mutations are the apolipoprotein $\mathrm{B}(A P O B)$ gene that causes defective binding of the LDL particle to the LDL-receptor and the gain of function mutation in the proprotein convertase subtilisin/kexin 9 (PCSK9) gene. Currently, over 1700 different LDLR mutations have been reported (Leigh 2016; lacocca 2018) but only one common $A P O B$ and one common PCSK9 mutation are seen (Humphries 2006a). Serum LDL cholesterol levels in untreated FH children are typically above $4 \mathrm{mmol} / \mathrm{L}$ (Wray 1996).

Coronary stenosis has been detected in men with $\mathrm{FH}$ as young as 17 years and in women with $\mathrm{FH}$ as young as 25 years of age (Mabuchi 1989). Indeed, early atherosclerosis, as determined by increased carotid intima-media thickness, is detectable in untreated $\mathrm{FH}$ children from the second decade of life (Tonstad 1996; Hoffmann 2002; Wiegman 2004).

\section{Description of the intervention}

It is necessary to start lifelong lipid-lowering measures in childhood in order to reduce the risk of cardiovascular disease in later life. Diet has so far been the main mode of treatment for children with FH (Poustie 2001; McCrindle 2012). Anion exchange resins, such as cholestyramine and colestipol, have been found to be effective but are unpalatable, poorly tolerated and therefore poorly adhered to by the patients (O'Connor 1990; Tonstad 1996).

Statins (3-hydroxy-3-methyl-glutaryl coenzyme A reductase inhibitors), are inhibitors of the rate-controlling enzyme in cholesterol synthesis, and have been available for lowering plasma LDL levels since the 1980s (Goldstein 1979; Goldstein 1990). Since the 1990s studies with statins have been carried out amongst children with $\mathrm{FH}$ aged 6 to 17 years and demonstrated a significant reduction in LDL levels (Knipscheer 1996).

\section{Why it is important to do this review}

The major serious side-effect of statin therapy is myopathy, defined as muscle pain with serum creatine kinase concentrations of more than $1000 \mathrm{U}$ per liter and in its extreme form rhabdomyolsis. These fortunately occur rarely (Bradford 1991; Joy 2009) and statins appear to be safe and well-tolerated in adults. While there is no evidence these adverse effects occur more commonly in children than adults, the long-term safety of statins amongst children is not well documented.

This review is an update of previously published versions of this Cochrane Review (Vuorio 2010; Vuorio 2014; Vuorio 2017).

\section{O B JECTIVES}

To assess the effectiveness and safety of statins in children with heterozygous $\mathrm{FH}$.

\section{METHODS}

\section{Criteria for considering studies for this review Types of studies}

Randomized and non-randomized but controlled clinical studies with systematic allocation.

\section{Types of participants}

Children and adolescents aged up to 18 years of age (at start of study) with clinical diagnosis of heterozygous $\mathrm{FH}$ based on genetic testing or clinical criteria (the level of serum total cholesterol is higher than the age-adjusted normal upper limit and at least one parent has been diagnosed with hypercholesterolemia).

\section{Types of interventions}

Active treatment with a statin (e.g. lovastatin, simvastatin, pravastatin, fluvastatin, rosuvastatin, atorvastatin, pitavastatin) compared to control treatment with another statin, or with placebo, or with other lipid-lowering agents (fibric acids, resins), or with diet alone or with no treatment.

\section{Types of outcome measures}

The ultimate goal of treatment with statins is to reduce the incidence of morbidity and mortality from cardiovascular diseases. These outcomes are rare in childhood, therefore, we used surrogate end points for assessing effectiveness. The 'change' means the difference between the values at the beginning and at the end of follow-up. We report the means of both absolute $(\mathrm{mmol} / \mathrm{L})$ and relative (\%) changes in lipids between groups.

We grouped outcome data into those measured at one month, at six months ( \pm two weeks), at one year ( \pm four weeks) and at two years. These are time points commonly used in clinical studies for evaluating drug effects and there was no statin-specific reason for the selection.

\section{Primary outcomes}

1. Change in carotid intima-media thickness

2. Change in serum LDL cholesterol level

3. Change in measures of growth and maturation, e.g. age of onset of puberty

\section{Secondary outcomes}

1. Liver dysfunction: change in aspartate aminotransferase (AST) and alanine aminotransferase (ALT) levels

2. Myopathy: change in serum creatine kinase (CK) levels

3. Rhabdomyolysis (degeneration of skeletal muscle tissue) or death due to rhabdomyolysis 
4. Change in endothelial function (measured by flow-mediated dilation of the brachial artery)

5. Change in serum total and high-density lipoprotein (HDL) cholesterol and triglyceride (TG) level

6. Quality of life

7. Compliance to study medication

8. Other adverse events which may be associated with statins

\section{Search methods for identification of studies}

There were no restrictions regarding language or publication status.

\section{Electronic searches}

Relevant studies were identified from the Group's Inborn Errors of Metabolism Trials Register using the terms: (*Hypercholesterolemia*:ti,ab,kw,mh,emt,misc1) AND ( ${ }^{\star}$ Statin $\left.{ }^{\star}: \mathrm{ti}, \mathrm{ab}, \mathrm{kw}, \mathrm{mh}, \mathrm{emt}, \mathrm{misc} 1\right)$.

The Inborn Errors of Metabolism Trials Register is compiled from electronic searches of the Cochrane Central Register of Controlled Trials (CENTRAL) (updated with each new issue of the Cochrane Library), weekly searches of MEDLINE and the prospective handsearching of one journal - Journal of Inherited Metabolic Disease. Unpublished work is identified by searching through the abstract books of the Society for the Study of Inborn Errors of Metabolism conference and the SHS Inborn Error Review Series. For full details of all searching activities for the register, please see the relevant section of the Cochrane Cystic Fibrosis and Genetic Disorders Group's website.

Date of most recent search: 04 November 2019.

We searched the following trials registries:

- the World Health Organization (WHO) International Clinical Trials Registry Platform (www.who.int/trialsearch)

- Clinicaltrials.gov (www.clinicaltrials.gov)

See an appendix for details of the searches (Appendix 1).

\section{Searching other resources}

Additionally, we searched the references of retrieved reviews and original articles.

\section{Data collection and analysis}

\section{Selection of studies}

Two authors (AV, JK) independently assessed potentially eligible studies for their suitability for inclusion in the review. We resolved any disagreements by discussion.

\section{Data extraction and management}

The same two authors (AV, JK) independently extracted data from the studies using a study selection and data extraction form modified for this review. We resolved any disagreements by discussion. We present treatment with all statins combined as a single intervention when comparing to control or placebo. We did not undertake any formal subgroup analyses because the statins studied differed between studies.
When study reports presented standard errors (SE), we converted these to standard deviations ( $S D=S E x\urcorner$ square root of $n$ ). For several outcomes for one study, we combined the results of three intervention groups by using $n$-weighted averages of means and SDs (Knipscheer 1996). The respective equations are described in chapter 7 of theCochrane Handbook for Systematic Reviews of Interventions (Higgins 2011a).

\section{Assessment of risk of bias in included studies}

We originally assessed the methodological quality of included studies based on a method as described by Jüni (Jüni 2001). We have now related our judgements to the current Cochrane risk of bias tool, so that assessments of adequate relate to low risk of bias, inadequate to high risk of bias and unclear to unclear risk of bias (Higgins 2011b).

We independently assessed the following aspects of quality: generation of the allocation sequence (assessed as adequate, inadequate or unclear); concealment of allocation (assessed as adequate, inadequate or unclear); the degree of blinding; and the appropriateness of the statistical analyses (i.e. intention-to-treat or per protocol).

\section{Measures of treatment effect}

For binary outcomes, the results are presented as risk ratios (RR) with $95 \%$ confidence intervals (Cls). For continuous outcomes, the results are presented as mean differences (MD) with $95 \% \mathrm{Cls}$.

\section{Unit of analysis issues}

There were no special unit-of-analysis issues. Cross-over and cluster-randomized studies do not have a suitable design for the interventions being considered and we feel they are unlikely to be used in the future.

\section{Dealing with missing data}

There were no or only few missing data in the included studies.

\section{Assessment of heterogeneity}

The $I^{2}$ statistic was used to test the impact of heterogeneity between studies (Higgins 2003). We considered levels of heterogeneity as follows:

- $0 \%$ to $40 \%$ : might not be important;

- $30 \%$ to $60 \%$ : may represent moderate heterogeneity;

- $50 \%$ to $90 \%$ : may represent substantial heterogeneity;

- $75 \%$ to $100 \%$ : considerable heterogeneity.

\section{Assessment of reporting biases}

The use of a funnel plot to investigate the possibility of publication bias was not feasible due to the small number of included studies; for a funnel plot analysis, a minimum of 10 studies is required.

\section{Data synthesis}

Where feasible, we combined data using a fixed-effect model of analysis.

\section{Subgroup analysis and investigation of heterogeneity}

We planned to explore possible sources of methodological heterogeneity, such as study quality or design and completeness 
of follow-up. We also planned to consider possible sources of clinical heterogeneity, such as sex and age of the participants and the interventions being compared. We would have investigated these using subgroup analyses; however, this was not feasible due to the small number of included studies. If more studies are available for future updates of this review and we identify substantial heterogeneity, we will consider undertaking those subgroup analyses listed above.

\section{Summary of findings and quality of the evidence (GRADE)}

In a post hoc change from protocol, we have presented a summary of findings tables for the comparison of statins versus placebo for children with FH (Summary of findings for the main comparison).

The following outcomes were reported in the tables (chosen based on relevance to clinicians and consumers): change in carotid intima-media thickness; change in serum LDL cholesterol level; change in measures of growth and maturation, e.g. age of onset of puberty, liver dysfunction; change in aspartate and alanine aminotransferase levels; myopathy; change in serum creatine levels; change in endothelial function (measured by flow-mediated dilation of the brachial artery); other adverse events which may be associated with statins.

Outcomes were presented in the summary of findings table at the end of follow-up or latest reported follow-up time.

We determined the quality of the evidence using the GRADE approach; and downgraded evidence in the presence of a high risk of bias in at least one study, indirectness of the evidence, unexplained heterogeneity or inconsistency, imprecision of results, high probability of publication bias. We downgraded evidence by one level if they considered the limitation to be serious and by two levels if very serious.

\section{RES U L T S}

\section{Description of studies}

For further details please see the tables (Characteristics of included studies; Characteristics of excluded studies).

\section{Results of the search}

We found 25 potentially eligible studies of statins for treating children with FH. Nine randomized controlled studies were eligible for inclusion. Reasons for excluding the remaining studies are provided in a table (Characteristics of excluded studies).

\section{Included studies}

\section{Statins versus placebo}

Nine randomized placebo-controlled studies were included, with a total of 1177 children. The earliest study was published in 1996 (Knipscheer 1996) and the most recent in 2015 (Braaskamp 2015a).

\section{Study design}

Six studies had a multicenter design (Stein 1999; de Jongh 2002a; McCrindle 2003; Clauss 2005; Avis 2010; Braaskamp 2015a); the remaining studies were undertaken at a single center (Knipscheer 1996; Couture 1998; Wiegman 2004). The studies included a runin phase with a fat-restricted diet lasting from four weeks to three months. Only Wiegman averaged two measurements to obtain the baseline LDL cholesterol level (Wiegman 2004), all other studies carried out a single measurement.

The sizes of the study populations varied. Four studies had more than 100 children per treatment arm (de Jongh 2002a; McCrindle 2003; Wiegman 2004; Avis 2010). The remaining studies were much smaller, with group sizes ranging from 18 to 64 . In general, the intervention and follow-up time was short, median 24 weeks (range from six weeks to two years).

\section{Study participants}

As inclusion criteria, three studies defined lower and upper limits for LDL cholesterol, required the participant to be at Tanner stage II (small amount of long, downy hair with slight pigmentation at the base of the penis and scrotum or on labia majora) or higher at the start of the study, and required $\mathrm{FH}$ to be present in the family (Stein 1999; McCrindle 2003; Clauss 2005). Three studies had criteria for LDL cholesterol lower limits and required $\mathrm{FH}$ to be present in the family but did not have any criteria for sexual development (Knipscheer 1996; de Jongh 2002a; Wiegman 2004). One study based the inclusion on LDL cholesterol level and a positive DNA diagnosis of the participating child (Couture 1998). In addition, McCrindle had a criterion for the upper level of serum TG levels (McCrindle 2003); Wiegman required a positive DNA diagnosis in the first-degree relative of the participating child and used premature CVD in close relatives as an inclusion criterion (Wiegman 2004); and Knispcheer required that clinical manifestations of premature atherosclerosis had to be present before the age of 50 years in the first or second-degree relatives (Knipscheer 1996). In one study either DNA-based or clinical criteria were required in addition to specific criteria for the fasting LDL cholesterol value and for female Tanner stage (Avis 2010). In the most recent study either documented genetic effect or LDL-C $\geqq 160 \mathrm{mg} / \mathrm{dL}$ or LDL-C $>130 \mathrm{mg} /$ $\mathrm{dL}$ and male, early CVD in family, $\mathrm{HDL}-\mathrm{C}<45 \mathrm{mg} / \mathrm{dL}, \mathrm{TG}>150 \mathrm{mg} / \mathrm{dL}$, lipoprotein(a) $>75 \mathrm{nmol} / \mathrm{L}$, type 2 diabetes mellitus diagnosed and blood pressure $>95$ th percentile for age and height were required (Braaskamp 2015a).

Exclusion criteria were aimed at excluding children with concomitant diseases which elevate lipid levels or medications that could interact with statins and thus included homozygous FH; diabetes mellitus; anorexia nervosa; kidney, liver or thyroid disorders; concomitant other dyslipidemias; immunosuppressant drugs; or drugs that are potent inhibitors of cytochrome P-450 3A4. Lifestyle was not generally considered at inclusion, e.g. there were no criteria regarding alcohol consumption and only one study excluded smokers.

The age of the study participants ranged from 6 years to 18 years; $51 \%$ were males. The mean (SD) baseline LDL cholesterol in the study groups varied from 5.28 (1.08) $\mathrm{mmol} / \mathrm{L}$ (de Jongh 2002a) to $6.48(0.98) \mathrm{mmol} / \mathrm{L}$ (Stein 1999).

\section{Study interventions}

Two studies used lovastatin with daily doses of $40 \mathrm{mg}$ (Stein 1999; Clauss 2005), one pravastatin with doses of $5 \mathrm{mg}$ to $20 \mathrm{mg}$ (Knipscheer 1996), one pravastatin with doses of $20 \mathrm{mg}$ to $40 \mathrm{mg}$ (Wiegman 2004), one simvastatin with a dose of $20 \mathrm{mg}$ (Couture 1998), one simvastatin with a dose of $40 \mathrm{mg}$ (de Jongh 2002a), one atorvastatin with doses of $10 \mathrm{mg}$ to $20 \mathrm{mg}$ (McCrindle 2003), one rosuvastatin with doses of $5 \mathrm{mg}$ to $20 \mathrm{mg}$ (Avis 2010) and one pitavastatin with doses of $1 \mathrm{mg}$ to $4 \mathrm{mg}$ (Braaskamp 2015a). 


\section{Outcome measures}

Only four studies mentioned compliance as monitored by counting tablets (Couture 1998; Wiegman 2004; Clauss 2005; Avis 2010). Although one important exclusion criterion was the use of drugs that are potent inhibitors of cytochrome P-450 3A4 like macrolide antibiotics and ketoconazole, it was unclear how their use was monitored and avoided.

Changes in LDL cholesterol during the treatment were measured in all studies. The primary efficacy outcome in eight studies was an absolute or percentage change in LDL cholesterol (Knipscheer 1996; Couture 1998; Stein 1999; de Jongh 2002a; McCrindle 2003; Clauss 2005; Avis 2010; Braaskamp 2015a). In one study it was the change from baseline in mean carotid intima-media thickness (IMT) (Wiegman 2004). Four studies reported absolute LDL cholesterol concentrations and the mean percentage change in LDL cholesterol at the end of follow-up (Knipscheer 1996; McCrindle 2003; Clauss 2005; Avis 2010) and one reported the mean percentage change in LDL cholesterol (Couture 1998). Of the studies reporting absolute and mean percentage change, two reported the mean percentage change in LDL cholesterol at the end of follow-up (Stein 1999; de Jongh 2002a), one reported mean percentage change but not SD for this change (Braaskamp 2015a), one reported the mean absolute changes in LDL cholesterol during follow-up (Wiegman 2004), and one reported the relative difference between the mean $L D L$ values in the beginning and at the end of the study (Avis 2010). The study of Wiegman was therefore excluded from the follow-up LDL cholesterol analyses, which were carried out either by using LDL cholesterol concentrations or percentage reduction at the end of the follow-up. Five studies explicitly reported that they used the Friedewald formula to calculate LDL cholesterol (Knipscheer 1996; Couture 1998; Wiegman 2004; Clauss 2005; Avis 2010).

Clinically significant elevation in hepatic transaminase (AST or ALT) levels, possibly related to hepatotoxicity, was defined as more than three times the upper limit of normal (ULN). This measurement was reported in eight studies (Knipscheer 1996; Stein 1999; de Jongh 2002a; McCrindle 2003; Wiegman 2004; Clauss 2005; Avis 2010; Braaskamp 2015a). Clinically significant CK elevation related to possible myopathy or rhabdomyolysis (or both) was defined as more than 10 times the ULN. This measurement was reported in seven studies (Knipscheer 1996; Stein 1999; de Jongh 2002a; McCrindle 2003; Clauss 2005; Avis 2010; Braaskamp 2015a).

The effect of statins on puberty (defined as an increase in the Tanner stage) was reported in only three studies (de Jongh 2002a;
McCrindle 2003; Wiegman 2004). Height and weight measurements were carried out in some studies, but due to the short follow-up time, it is not possible to draw any further conclusions on their changes and are not examined in the present analysis.

Six studies reported adverse events (Knipscheer 1996; Stein 1999; de Jongh 2002a; McCrindle 2003; Clauss 2005) with one not separating treated participants from controls (Braaskamp 2015a). Muscular adverse events were reported as either myalgia or myopathy.

Given cholesterol is a precursor of steroid and sex hormones, four studies reported the results of plasma levels of these hormones (Stein 1999; de Jongh 2002a; Wiegman 2004; Clauss 2005). The differences between the treatment and placebo groups, although statistically significant, were small. Normal variability of these hormones is large at this age; thus we considered the differences to be of no clinical significance but exact significance is unknown.

Change in thickness of carotid intima was examined in only one study (Wiegman 2004).

There were no reports on quality of life.

\section{Excluded studies}

Of the 17 excluded studies, 13 did not have controls (Lambert 1996; Raal 1997; Stein 1999; Athyros 2002; Dirisamer 2003; Hedman 2003; Sinzinger 2004; Hedman 2005; van der Graaf 2006; Carreau 2011; Gandelman 2011; Braaskamp 2015b; Langslet 2016), one was carried out with a combination of colestipol resin and a statin (McCrindle 2002), one did not have clearly defined controls (Stefanutti 1999), one was not randomized (Braaskamp 2015c) and in one participants had homozygous FH (Stein 2016).

\section{Risk of bias in included studies}

In the original version of this review, methodological quality was assessed based on a method as described by Jüni (Jüni 2001). We primarily focused on the following aspects of study design: method and concealment of allocation, treatment and control group comparability at baseline, use of intention-to-treat analysis, and blinding. Loss to follow-up was reported heterogeneously and was difficult to grade. There was no indication to suspect selective reporting in any of the studies. For this update, these judgements have been related to the current risk of bias tool as described in chapter 8 of the Cochrane Handbook for Systematic Reviews of Interventions (Higgins 2011b). Please refer to the risk of bias graph (Figure 1). 
Figure 1. Risk of bias summary: review authors' judgements about each risk of bias item for each included study.

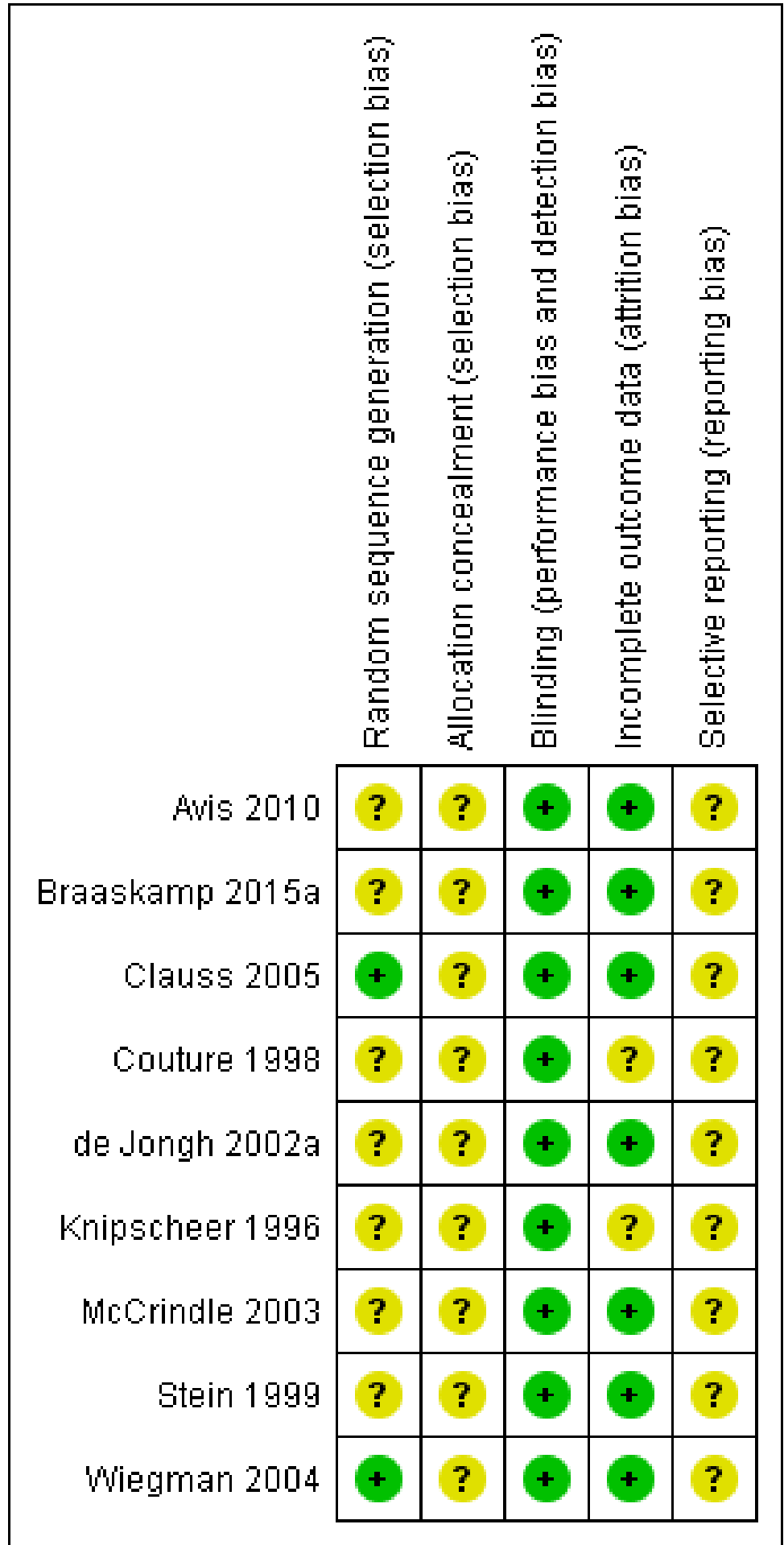

\section{Allocation}

\section{Generation of allocation sequence}

The generation of the allocation sequence was adequate in two studies since the sequence was computer-generated (Wiegman 2004; Clauss 2005). In two studies (unclear risk), it was stated that groups were stratified but the randomization procedure was not described (Knipscheer 1996; Avis 2010). The remaining five studies were described as randomized, but no further details of the process were given (also unclear risk of bias) (Couture 1998; Stein 1999; de Jongh 2002a; McCrindle 2003; Braaskamp 2015a).

\section{Concealment of allocation}

None of the included studies described how the allocation sequence was concealed from the investigators, the outcome 
assessors or the participants in the study (unclear risk of bias). However, one study (Avis 2010) reported randomization was stratified by center, and there was one multicenter study (Braaskamp 2015a); both of these were assumed to have been centrally randomized.

\section{Blinding}

All studies were described as double blind, indicating that participants and those participating in treatment procedures were blinded to treatment (low risk).

\section{Incomplete outcome data}

Dropout rates were reported in seven studies (low risk of bias) (Stein 1989; de Jongh 2002a; McCrindle 2003; Wiegman 2004; Clauss 2005; Avis 2010; Braaskamp 2015a); these were low, varying from $2 \%$ (McCrindle 2003) to 8\% (Stein 1999). Two studies did not present a report on dropout rates (unclear risk of bias) (Knipscheer 1996; Couture 1998).

\section{Effects of interventions}

See: Summary of findings for the main comparison

Please refer to the 'Summary of Findings table' for explanations of the assessments of the quality of the evidence (Summary of findings for the main comparison).

\section{Statins versus placebo}

\section{Primary outcomes}

\section{Change in thickness of carotid intima}

One study reported on this outcome (Wiegman 2004). This study showed that two years of pravastatin therapy induced a small but significant regression of IMT compared to placebo which was -0.01 $\mathrm{mm}(95 \% \mathrm{Cl}-0.03$ to -0.00$)$ (low-quality evidence) (Analysis 1.1).

\section{Change in serum LDL cholesterol level}

Five studies reported the difference between mean relative reductions of serum LDL cholesterol levels (Knipscheer 1996; Stein 1999; (de Jongh 2002a; McCrindle 2003; Clauss 2005). One study reported only changes in absolute lipid levels (Wiegman 2004), one study reported lipid levels in graph form only (Couture 1998); LDL cholesterol data from these two studies were not analysed. One study reported $L D L$ cholesterol levels using the relative difference between the mean LDL values in the beginning and at the end of the study (Avis 2010) and one study reported LDL cholesterol mean percentage change without SD (Braaskamp 2015a). The quality of the evidence was judged to be high.

At one month (three studies) the pooled estimate of the difference in mean relative reductions was $-24.59 \%(95 \% \mathrm{Cl}-30.11$ to -19.08$)$ (Knipscheer 1996; Clauss 2005; Braaskamp 2015a), at six months (four studies) it was $-34.97 \%(95 \% \mathrm{Cl}-37.51$ to -32.44$)$ (Stein 1999; de Jongh 2002a; McCrindle 2003; Clauss 2005) and at one year (two studies) it was $-26.94 \%(95 \% \mathrm{Cl}-31.64$ to -22.23$)$ (Stein 1999; de Jongh 2002a) (Analysis 1.2).

The difference in mean relative reductions in LDL cholesterol concentration at end of follow-up (median 24 weeks) between those treated with statins and those with a placebo varied from $-21 \%$ to $-41 \%$. The pooled estimate of the difference in mean relative reductions at the end of follow-up (six studies) was $-32.15 \%$
(95\% Cl -34.90 to -29.40 ) (high-quality evidence) (Knipscheer 1996; Stein 1999; de Jongh 2002a; McCrindle 2003; Clauss 2005; Braaskamp 2015a) (Analysis 1.2).

The studies can be considered clinically comparable even though the results showed statistical heterogeneity. This heterogeneity was present at six months $\left(I^{2}=86 \%\right)$ and at one year $\left(I^{2}=81 \%\right)$, but not at one month. The heterogeneity is most likely due to multiple factors such as variation in statin type, statin dosage and duration of study.

\section{Change in measures of growth and maturation}

Three studies reported measures of growth (de Jongh 2002a; McCrindle 2003; Wiegman 2004). The effect of statins on puberty was measured by the change in Tanner stage. McCrindle reported percentage of groups experiencing an increase in Tanner stage and we calculated the number of events from this in order to enter data into the meta-analysis. The pooled estimate of the RR at six months (two studies) was $-0.99(95 \% \mathrm{Cl}-0.66$ to 1.50$)$ (de Jongh 2002a; McCrindle 2003), at one year (one study) 0.89 (95\% Cl 0.51 to 1.54) (de Jongh 2002a) and at two years (one study) 0.95 (95\% Cl 0.77 to 1.18) (low-quality evidence) (Wiegman 2004) (Analysis 1.3).

\section{Secondary outcomes}

\section{Liver dysfunction}

\section{a. Change in AST levels}

Seven studies reported levels of AST (Knipscheer 1996; Stein 1999; de Jongh 2002a; McCrindle 2003; Wiegman 2004; Clauss 2005; Braaskamp 2015a). At one month there were no cases reported (Knipscheer 1996; Braaskamp 2015a), at six months (four studies) the estimate of the RR was 2.40 (95\% Cl 0.29 to 19.85) (Stein 1999; de Jongh 2002a; McCrindle 2003; Clauss 2005), at one year (two studies) 2.03 (95\% Cl 0.08 to 49.09) (Stein 1999; de Jongh 2002a) and at two years (one study) 0.21 (95\% $\mathrm{Cl} 0.01$ to 4.23 ) (low-quality evidence) (Wiegman 2004) (Analysis 1.4).

\section{b. Change in ALT levels}

Seven studies reported levels of ALT (Stein 1989; Knipscheer 1996; de Jongh 2002a; McCrindle 2003; Wiegman 2004; Clauss 2005; Braaskamp 2015a). There were no cases reported at one month (Knipscheer 1996; Braaskamp 2015a) or at two years (Wiegman 2004). At six months (four studies) the estimate of the risk ratio was 2.03 (95\% Cl 0.24 to 16.95) (Stein 1999; de Jongh 2002a; McCrindle 2003; Clauss 2005) and at one year (two studies) 2.03 (95\% Cl 0.08 to 49.09) (low-quality evidence) (de Jongh 2002a; Stein 1999) (Analysis $1.5)$.

\section{Myopathy: change in serum CK levels}

Six studies reported the change in serum CK levels (Stein 1989; Knipscheer 1996; de Jongh 2002a; Clauss 2005; Avis 2010; Braaskamp 2015a). At one month (three studies) the pooled estimate of the RR was 3.23 ( $95 \% \mathrm{Cl} 0.18$ to 58.84) (Knipscheer 1996; Avis 2010; Braaskamp 2015a), at six months (two studies) it was RR 0.22 (95\% Cl 0.01 to 5.28) (de Jongh 2002a; Clauss 2005) and at one year (two studies), RR 0.67 ( $95 \% \mathrm{Cl} 0.04$ to 10.57) (low-quality evidence) (Stein 1999; de Jongh 2002a) (Analysis 1.6).

\section{Rhabdomyolysis}

There were no reported cases of rhabdomyolysis. 


\section{Change in endothelial function}

The change in endothelial function was reported in a sub-study of the 2002 de Jongh study, among 28 participants treated with statins and 22 treated with placebo (de Jongh 2002a). The absolute change in relative flow-mediated dilatation of brachial artery was $2.70 \%$ (95\% Cl 0.42 to 4.98 ) (low-quality evidence) (de Jongh 2002a) (Analysis 1.7).

\section{Change in serum total cholesterol, HDL cholesterol and TG levels}

\section{a. Change in serum total cholesterol levels}

Five studies reported the difference between mean relative reductions of serum total cholesterol levels (Stein 1989; Knipscheer 1996; de Jongh 2002a; McCrindle 2003; Clauss 2005). One study reported mean relative reductions of serum total cholesterol levels but not the SDs (Braaskamp 2015a).

At one month (three studies) the pooled estimate of the difference in mean relative reductions was $-18.31 \%(95 \% \mathrm{Cl}-22.55$ to -14.06$)$ (Knipscheer 1996; Clauss 2005; Braaskamp 2015a), at six months (four studies) $-24.28 \%(95 \% \mathrm{Cl}-26.09$ to -22.47 ) (Stein 1999; de Jongh 2002a; McCrindle 2003; Clauss 2005) and at one year (two studies) $-27.60 \%$ (95\% Cl -30.64 to -24.57) (Stein 1999; de Jongh 2002a) (Analysis 1.8)

The difference in mean relative reductions in total cholesterol concentration at the end of the follow-up (median 24 weeks) between those treated with a statin and those with a placebo varied from $-17 \%$ to $-32 \%$. The pooled estimate of the difference in mean relative reductions at the end of follow-up (six studies) was $-26.53 \%$ (95\% Cl -28.54 to -24.51 ) (Knipscheer 1996; Stein 1999; de Jongh 2002a; McCrindle 2003; Clauss 2005; Braaskamp 2015a) (Analysis 1.8).

The studies can be considered clinically comparable even though the results showed statistical heterogeneity. This heterogeneity was not present at one month, but it was present at six months $\left(I^{2}\right.$ $=87 \%)$ and at one year $\left(1^{2}=95 \%\right)$.

\section{b. Change in serum HDL cholesterol levels}

Five studies reported the difference between mean relative reductions of serum HDL cholesterol levels (Knipscheer 1996; Stein 1999; de Jongh 2002a; McCrindle 2003; Clauss 2005). One study reported $\mathrm{HDL}$ cholesterol levels using the relative difference between the mean HDL values in the beginning and at the end of the study (Avis 2010) and one study reported mean percentage change in HDL cholesterol without SD (Braaskamp 2015a).

At one month (three studies) the pooled estimate of the difference in mean relative change was $3.00 \%(95 \% \mathrm{Cl}-2.47$ to 8.47$)$ (Knipscheer 1996; Clauss 2005; Braaskamp 2015a), at six months (four studies) $4.18 \%$ (95\% Cl 1.54 to 6.82) (Stein 1999; de Jongh 2002a; McCrindle 2003; Clauss 2005) and at one year (two studies) $2.56 \%$ ( $95 \% \mathrm{Cl}-1.17$ to 6.29 ) (Stein 1999; de Jongh 2002a) (Analysis 1.9).

The difference in mean relative reductions in HDL cholesterol concentration at the end of the follow-up (median 24 weeks) between those treated with statins and those with a placebo varied from $0 \%$ to $5 \%$. The pooled estimate of the difference in mean relative changes at the end of follow-up (six studies) was 3.11\% (95\% Cl 0.55 to 5.67) (Knipscheer 1996; Stein 1999; de Jongh 2002a; McCrindle 2003; Clauss 2005; Braaskamp 2015a) (Analysis 1.9).

\section{c. Change in serum TG levels}

Four studies reported the difference between mean relative reductions of serum TG levels (Knipscheer 1996; Stein 1999; McCrindle 2003; Clauss 2005). One study reported TG levels using the relative difference between the mean TG values in the beginning and at the end of the study (Avis 2010) and one study reported mean percentage change without the SD (Braaskamp 2015a).

At one month (three studies) the pooled estimate of the difference in mean relative change was $10.31 \%(95 \% \mathrm{Cl}-5.11$ to 25.74$)$ (Knipscheer 1996; Clauss 2005; Braaskamp 2015a), at six months (three studies) -9.34\% (95\% Cl-18.90 to 0.22) (Stein 1999; McCrindle 2003; Clauss 2005) and at one year (one study) $0.00 \%$ (95\% Cl-18.09 to 18.09) (Stein 1999) (Analysis 1.10).

The difference in the mean relative reductions in TG concentration at the end of follow-up (median 24 weeks) between those treated with statins and those with a placebo varied from $-7 \%$ to $16 \%$. The pooled estimate of the difference in mean relative reductions at the end of follow-up (five studies) was $-3.27 \%(95 \% \mathrm{Cl}-12.03$ to 5.50) (Knipscheer 1996; Stein 1999; McCrindle 2003; Clauss 2005; Braaskamp 2015a) (Analysis 1.10).

\section{Quality of life}

No study reported this outcome.

\section{Compliance}

Compliance was reported in one study by tablet counting and it was found most children adhered to the protocol, i.e. $84 \%$ of tablets were taken for the full length of the two-year study (Wiegman 2004).

\section{Adverse events}

Six studies reported clinical adverse events (Knipscheer 1996; Stein 1999; de Jongh 2002a; McCrindle 2003; Clauss 2005; Avis 2010). At one month (two studies) the estimate of the RR was 0.86 (95\% Cl 0.65 to 1.13) (Knipscheer 1996; Avis 2010), at six months (three studies) 1.02 ( $95 \%$ Cl 0.82 to 1.27) (de Jongh 2002a; McCrindle 2003; Clauss 2005) and at one year (two studies) 1.01 (95\% Cl 0.81 to 1.26 ) (moderate-quality evidence) (Stein 1999; de Jongh 2002a) (Analysis 1.11).

\section{DISCUSSION}

\section{Summary of main results}

We analysed nine randomized placebo-controlled studies in children with heterozygous $\mathrm{FH}$. The studies showed a clinically significant reduction in both serum total cholesterol and LDL cholesterol among children treated with a statin compared with those treated with a placebo. In addition, statin therapy slightly increased serum HDL cholesterol and slightly decreased serum triglyceride concentration; however, when compared with the substantial change in serum LDL cholesterol, these changes are likely to be of minor importance. The magnitude of LDL cholesterol lowering varied from study to study, most likely due to different statins and doses and possibly due to different definitions about true monogenic heterozygous $\mathrm{FH}$. We did not do any formal subgroup analyses because the choice of statin treatment was heterogeneous between studies.

Endothelial dysfunction represents one of the earliest stages of atherogenesis, and has a clear predictive value for future 
cardiovascular disease. A number of studies have shown that endothelial function measured as flow-mediated dilation is impaired in children with FH (de Jongh 2002b; Vlahos 2014). The effect of simvastatin on flow-mediated dilatation of the brachial artery in children with $\mathrm{FH}$ was reported in one study (de Jongh 2002a). There is evidence that simvastatin therapy may slightly restore endothelial function in the studied participants (50 children with FH; 9 to 18 years) (low-quality evidence). Clearly more studies are needed to confirm this result in children with $\mathrm{FH}$.

In addition to early changes in the function of the arterial endothelium in children with $\mathrm{FH}$, which result from the high LDL cholesterol concentration in the blood, accumulation of the LDL cholesterol in the subendothelial space of the carotid arterial wall leads to increased IMT of the carotid arteries (Tonstad 1996). Carotid IMT represents the combined intima and media thickness of the arterial wall, and numerous studies have shown that this surrogate marker of atherosclerotic vessel wall change is a reliable indicator of clinical outcomes later in life (Koeijvoets 2005). Accordingly, studies examining the sensitivity of this surrogate marker to risk intervention are important. We found only one study that used carotid IMT as the primary efficacy outcome in children with FH treated with statins (Wiegman 2004). The authors found that two years of pravastatin therapy induced a small but significant regression in mean change in IMT between statin-treated and placebo groups in children with $\mathrm{FH}$. Given we have assessed this as low-quality evidence, we can conclude that pravastatin may induce regression in carotid intima media thickness. This clearly encouraging result calls for further studies with pravastatin or other statins.

In the largest study, all children were from families where a molecular diagnosis had been made in one parent and where the recruited child had LDL cholesterol twice greater than $4.0 \mathrm{mmol} /$ L. The authors judged this to mean the child had a greater than 99.6\% chance of having inherited the family mutation (Wiegman 2004).This sample is therefore highly likely to consist of all FH individuals. In the most recent study (Braaskamp 2015a), all children had a mutation in $\angle D L R$ or $A P O B$ genes or had a parent where the mutation had been identified, and thus all of these children have molecularly defined monogenic FH. In all the other studies, children were recruited as having LDL cholesterol above a cut-off point which varied between the studies (Starr 2008). The other criterion was having a first degree relative, either with elevated LDL cholesterol, or with a family history of premature coronary artery disease. It is therefore likely the vast majority of the children in the studies included in this review have monogenic $\mathrm{FH}$ but it cannot be ruled out that a small percentage (not more than $10 \%)$ may not have.

Although in the majority of studies published in recent years molecular testing was performed and only mutation-positive participants recruited, the diagnosis of $\mathrm{FH}$ was not confirmed by direct molecular testing of the children in some of the earlier studies included in this review. Although idiopathic elevated LDL cholesterol levels occur less frequently in children than in adults, this raises the question of whether only a proportion of the children in the earlier studies have true monogenic FH. This may affect the conclusions made above, since the lipid-lowering response to a statin may be different in mutation carriers compared to those with a polygenic cause of their phenotype. In adults with a clinical diagnosis of "definite" FH a causative mutation can be found in between $70 \%$ to $80 \%$ of individuals, while only around $30 \%$ of people with a clinical diagnosis of "possible" FH carry a causative mutation (Graham 2005; Humphries 2006b; Futema 2013). It is now known that in people with a clinical diagnosis of $\mathrm{FH}$ but with no detectable mutation in any of the three common $\mathrm{FH}$ genes there is a polygenic (not a monogenic) cause of their phenotype (Talmud 2013), and they have been incorrectly been given the diagnosis of $\mathrm{FH}$. This polygenic cause has also been demonstrated to explain the elevated LDL-C levels in children with a diagnosis of $\mathrm{FH}$ where no mutation can be found (Futema 2015).

In the absence of molecular confirmation, it is possible to estimate the probable dilution of monogenic FH children with children with a polygenic aetiology from family studies. There is a considerable overlap in LDL-cholesterol levels in the mutation-carrying and nonmutation carrying siblings of a parent with $\mathrm{FH}$, such that using the intersection between the two peaks of LDL-cholesterol levels observed results in a false positive diagnostic rate of $6 \%$ to $8 \%$ (Kwiterovich 1974; Leonard 1976). Thus selecting children as "FH" based only on having a parent with FH and elevated LDL-C levels may have resulted in the inclusion of $6 \%$ to $8 \%$ non-mutation carriers, in earlier studies where no DNA testing was carried out. Based on this we can conclude that the earlier published estimates of the effect of statin treatment in children with a clinical diagnosis of FH where no molecular testing had been performed are unlikely to have been significantly influenced by the incorrect inclusion of non-monogenic individuals.

The importance of distinguishing between monogenic and polygenic elevation of LDL cholesterol is whether children with a monogenic cause might have a much smaller than average LDL cholesterol-lowering response than children whose hypercholesterolaemia is due to polygenic causes. Although we are not aware of any data addressing this directly in children, there is evidence that adults with a clinical diagnosis of $\mathrm{FH}$ without a detected mutation have a better response to statins than those in which a mutation has been found (Sun 1998; Heath 1999). Another issue to consider is that children with different $L D L R$ mutations, or in those where $\mathrm{FH}$ is caused by mutations in the $A P O B$ or PCSK9 genes, may respond differently to statins. There is no direct evidence for this in children, but adults carrying the $A P O B$ mutation have been reported to respond better to statins than those carrying an LDLR mutation (Myant 1993) or a PCSK9 mutation (Humphries 2006b). Furthermore, the class of $L D L R$ mutation can affect the untreated LDL cholesterol levels (Humphries 2006b; Futema 2013) and affect the response to statins (Couture 1998; Vohl 2002; Miltiadous 2005). These variations according to mutations are pertinent because founder effects are seen in many countries, e.g. South Africa (Kotze 1993), Finland (Vuorio 2001) and Holland, (Umans 2002). Thus the variability in the prevalence of different mutations and molecular causes of $\mathrm{FH}$ across countries may contribute to a small extent to betweenstudy differences in response but although there may be a small overestimate of the response in statin-sensitive mutation-carrying FH children, it is unlikely to be more than 5\% (van der Graaf 2011).

Recent guidelines vary in their recommendations as to when statin treatment should be started between 8 years to 14 years (McCrindle 2007; SIGN 2007; Daniels 2008; NICE 2008; Descamps 2011; Goldberg 2011; Sullivan 2012). None of the guidelines recommended statins before the age of eight years in cases of heterozygous FH (Vuorio 2013). In regard to dosing, this varied 
considerably between the studies. In the earliest study, children with $\mathrm{FH}$ were treated with pravastatin doses from $5 \mathrm{mg} /$ day to 20 $\mathrm{mg} /$ day (Knipscheer 1996). In the later studies there was a tendency to use larger doses. Wiegman used pravastatin doses of $20 \mathrm{mg} /$ day or $40 \mathrm{mg} /$ day (Wiegman 2004), and de Jongh titrated simvastatin doses of up to $40 \mathrm{mg} /$ day (equivalent dose of pravastatin, 80 $\mathrm{mg} /$ day) (de Jongh 2002a). McCrindle titrated atorvastatin doses from $10 \mathrm{mg} /$ day up to $20 \mathrm{mg} /$ day (equivalent dose of pravastatin, up to $80 \mathrm{mg} /$ day) if the LDL cholesterol level remained over $3.4 \mathrm{mmol} / \mathrm{L}$ (McCrindle 2003). In this study the mean serum LDL cholesterol concentration among $\mathrm{FH}$ children treated with statins was $3.39 \mathrm{mmol} / \mathrm{L}$ at the end of follow-up. In the most recent study (Braaskamp 2015a), the $5 \mathrm{mg}$ starting dose of rosuvastatin was titrated at 3-monthly intervals to a maximum tolerated dose of 10 $\mathrm{mg}$ (six-to nine-year olds) or $20 \mathrm{mg}$ (10-to 17 -year olds) to achieve an LDL-C goal of $(2.85 \mathrm{mmol} / \mathrm{L}(110 \mathrm{mg} / \mathrm{dL})$. In all cases the minimal effect dose is advised.

It has been estimated that elevations in aminotransferase levels over three times the upper limit of normal occur in less than $1 \%$ of adults on any statin (Cohen 2006). However, there was no increase in aminotransferase levels when compared with a placebo group in a recent meta-analysis (de Denus 2004), and adults with elevated aminotransferase levels during statin treatment do not appear to have a higher risk of liver dysfunction (Chalasani 2004). The risk of acute severe liver dysfunction in the general population with no statin medication is about one to two cases per million (Law 2006). Consequently, severe liver dysfunction is extremely rare and routine monitoring is recommended, but it will be effective only when it is active and includes not only laboratory test but also clinical follow-up (Golomb 2013). The studies of children with FH used liver transaminases as the method for detecting possible liver dysfunction. The putative risk of statin-induced severe acute liver dysfunction at this stage of life should be outweighed by the reduced cardiovascular risk achieved by statin treatment (NICE 2008). The most recent guidelines by the National Lipid Association's Statin Safety Assessment Task Force give some useful considerations (McKenney 2006). They underline the importance of monitoring any possible symptoms like abdominal pain related to liver dysfunction and advise to consider using a fractionated bilirubin for detection of liver dysfunction. This kind of monitoring was carried out systematically in only half of the studies we analyzed, and the monitoring protocol varied between the studies (Stein 1999; de Jongh 2002a; Wiegman 2004; Clauss 2005). None of the studies included fractionated bilirubin in their laboratory analysis. It can be concluded that even though liver dysfunction was not present in the included studies, the risk exists. Therefore, any new studies of children with $\mathrm{FH}$ should be planned so that possible hepatotoxicity symptoms are routinely monitored using standardized methods and, additionally, new laboratory standards should be used in detecting possible liver dysfunction.

The incidence of rhabdomyolysis has been estimated to be about 3.4 per 100,000 person-years in adults (Law 2006). Although this figure is very low, the lesson learned with cerivastatin should be keenly kept in mind (Pasternak 2002). The rate of fatal rhabdomyolysis with this drug was unexpectedly and exceptionally high; 16 to 80 times greater than with other statins (Staffa 2002) and even after excluding individuals treated simultaneously with gemfibrozil, the rate of fatal rhabdomyolysis was still 10 to 50 times higher than of other statins (Staffa 2002). All statins used so far in children with FH (atorvastatin, lovastatin, pravastatin, and simvastatin) appear to have a low risk of rhabdomyolysis as compared to adults, which is estimated to be about $0.08 \%$ to $0.09 \%$ of persons treated with these statins (Pasternak 2002). Since the mechanism of myopathy is not well understood, it is of the utmost importance to monitor adverse reactions and adjust the therapy accordingly (Pasternak 2002).

The terminology of clinical adverse events in the analyzed studies varied. The comparison between the studies would have been more reliable if the definition of adverse events had been standardized. It is important to note that some drugs that interact with statins (macrolide antibiotics and azole fungals) may have been consumed, thus altering the adverse event risk. In practice any interaction risk can be mitigated with patient education. Statin therapy combined with alcohol abuse potentially increases the risk of liver dysfunction. Alcohol consumption was not monitored in any of the included studies; however, alcohol abuse is uncommon in children but when adolescence is reached discussions about alcohol consumption should be had with the young person. It is unclear as to whether statins increase the risk of cataracts with about equal numbers of studies supporting the theory versus those against (Harris 1995; Cenedella 1996; Pedersen 1996; Chodick 2010; Hippisley-Cox 2010; Fong 2012; Leuschen 2013).

One of the potential long-term side effects of statin treatment in children with $\mathrm{FH}$ is the increased risk of developing type 2 diabetes (T2D) that has been noted in statin treatment of non-FH individuals. A meta-analysis of published randomized controlled trials in over 91,000 high risk individuals from the general population (Sattar 2010) reported statin therapy was associated with a $9 \%$ increase in the likelihood of new T2D during follow-up. This association between increased likelihood developing T2D has been also shown among children and adolescents ( Joyce 2017 ). Interestingly, a second meta-analysis showed pravastatin (40 mg/day) was associated with the lowest $(7 \%)$, atorvastatin $(80 \mathrm{mg} /$ day) with an intermediate (15\%) and rosuvastatin (20 mg/day) and simvastatin ( $40 \mathrm{mg} /$ day) with the highest $(25 \%$ and $21 \%$ respectively) risk of new onset T2D (Navarese 2013). The exact molecular mechanism of this statin-associated T2D risk is unknown (please refer to the references in Vuorio 2016), and it is unclear whether this is an on-target or off-target effect of the drug; that is, whether the dysglycaemic effect is a direct consequence of inhibition of HMG-CoA, the intended target of statins. Using the approach of Mendelian Randomisation, variants in the gene encoding HMGCoA reductase (HMGCR, chr 5q13.3) associated with lower LDL-C were used as proxies for statin treatment. Both statin treatment and the genetic variants were associated with higher T2D risk and higher bodyweight, and the genetic variants with higher plasma glucose and insulin, and waist and hip circumferences (Swerdlow 2015). This directional concordance strongly suggested that the higher T2D risk caused by statin therapy is at least in part a direct consequence of HMG-CoA reductase inhibition. Reassuringly, many studies have reported that the prevalence of T2D is low in adults with $\mathrm{FH}$, and in a study of over 63,000 people from Holland (Besseling 2015), even in treated adults with $\mathrm{FH}$ the prevalence of T2D was significantly lower than in their unaffected relatives (1.75\% versus $2.93 \%)$. Follow-up studies in adults (Skoumas 2014) and in children (Kusters 2014) are also reassuring, with 10-year follow-up in 194 statin-treated children (mean age at baseline 13 years) seeing one new case of T2D, with a similar incidence in their 83 non-FH siblings (Kusters 2014). It is clear that overall the benefits of statin treatment for preventing cardiovascular disease 
in people with $\mathrm{FH}$ far outweighs the modest potential risk of T2D. It is possible the dietary and lifestyle advice given to all people with $\mathrm{FH}$ encourages them to maintain an ideal body weight and thus to ameliorate any of the statin-associated risk of developing T2D. Based on published evidence it would appear that treatment with pravastatin is associated with the lowest risk, although long-term follow-up studies of treated FH children are needed to confirm this.

Relatively little is known about the potential statin-related neurologic side-effects such as sleep disturbances (Bays 2006), effects on cognitive function and peripheral neuropathy (Backes 2003; Chong 2004). In most cases, the onset of symptoms was reported within six months of commencing medication, and most of the peripheral neuropathies were confirmed by nerve conduction studies. The reports were related to all statins, and discontinuation of statin treatment improved the symptoms. In a recent review based on adult studies, peripheral neuropathy was concluded to be an idiosyncratic effect of statin use (Brass 2006). In the included studies Wiegman showed that there was no difference on academic performance between the statin treated and placebo group (Wiegman 2004).

Particularly important are the concerns related to any potential impact on sexual and physical maturation (McCrindle 2007). Long-term effects on maturation will need to be studied in longer and larger controlled follow-up studies. Physical maturation was followed in some studies by measuring height but this is unreliable in short-term studies. There is concern about pregnancy during statin treatment (McCrindle 2007) as statins can affect foetal development. Females of child-bearing age should receive counselling and contraceptive advice (Arambepola 2007; McCrindle 2007; NICE 2008; Nordestgaard 2013).

In summary, this review found statins to be an effective treatment for $\mathrm{FH}$ in children. It did not find any difference between the statin and control group in the proportion of participants who experienced a clinically significant increase in liver transaminase values (over three-fold increase in alanine transferase or aspartate aminotransferase) or creatine kinase values (over 10-fold increase). We did not find any significant difference between those treated with a statin and those treated with placebo with respect to their sexual maturation measured by the Tanner staging. Overall, the data suggest the risk of adverse events in children treated with statins is similar to that observed in statin-treated adults over the short term and the adverse event rate was the same between statin and placebo group. In the absence of long-term treatment and follow-up of children, it is not possible to rule out any long-term adverse effects. Our findings are similar to those reported in two systematic reviews (Arambepola 2007; Avis 2007).

\section{Overall completeness and applicability of evidence}

The quality of the data concerning change in serum LDL cholesterol and adverse events was, according to GRADE, classified as high and moderate, respectively. These data are applicable in the treatment of FH children. In conclusion, statins lowered LDL cholesterol effectively (advantage). Significant adverse events were not present during the statin treatment (potential harm).

\section{Quality of the evidence}

Blinding (performance bias and detection bias) was not present in any studies. Bias from random sequence generation (selection bias) was not present in two studies and the data were not clearly stated in seven studies. Bias from allocation concealment (selection bias) and selective reporting (reporting bias) can not totally be excluded, but it is very unlikely. In conclusion it can be stated that all the studies appeared to be well run and we do not think any above mentioned factors will influence the results in a negative way. Quality of evidence varied from high (change in serum LDL cholesterol) through moderate (adverse events) to low (change in carotid intima-media thickness, change in measures if growth and maturation, liver dysfunction, myopathy and change in endothelial function).

\section{Potential biases in the review process}

A comprehensive literature search was carefully carried out and we consider that most controlled studies were identified. Study protocols varied between the included studies and data were presented slightly differently between the studies. In conclusion we found no potential bias in the review process.

\section{Agreements and disagreements with other studies or reviews}

Our findings are similar to those reported in two systematic reviews (Arambepola 2007; Avis 2007). In the Arabepola review, results of a parallel-group randomized placebo-controlled trial concerning heterozygous FH children with $\mathrm{LDL}$ and $\mathrm{HDL}$ cholesterol and triglycerides as outcomes were pooled using standard metaanalytical methods (Arambepola 2007). In the Avis review, they performed a meta-analysis of randomized, double-blind, placebocontrolled trials evaluating statin therapy in children aged 8 to 18 years with heterozygous $\mathrm{FH}$ and six studies ( $\mathrm{n}=798$ children) with 12 to 104 weeks of treatment were included (Avis 2010).

\section{AUTHORS' CONCLUSIONS}

\section{Implications for practice}

Statin treatment is an effective lipid-lowering therapy in children with heterozygous familial hypercholesterolaemia (FH). No safety issues were identified in the short term up to two years. Since statin treatment in children with $\mathrm{FH}$ is not acutely or subacutely a life-saving treatment, it would be difficult to accept any clinically significant adverse events in this patient group. This treatment should be combined with regular pediatric follow-up and parents informed about potential side-effects and interaction with concomitant medication.

\section{Implications for research}

Much larger and longer-term randomized clinical trials are needed to ensure that statins are a safe therapy in the long term in children. Growth, neurological development, cognitive function and quality of life should be assessed during follow-up.

\section{ACKNOWLEDGEMENTS}

The Finnish Office for Health Technology Assessment, National Research and Development Centre for Welfare and Health has financially supported the preparation of this review.

This project was supported by the National Institute for Health Research, via Cochrane Infrastructure funding to the Cochrane Cystic Fibrosis and Genetic Disorders Group. The views and opinions expressed therein are those of the authors and do not 
necessarily reflect those of the Systematic Reviews Programme, NIHR, NHS or the Department of Health. 


\section{RE F E R E N C E S}

\section{References to studies included in this review}

Avis 2010 \{published data only\}

Avis HJ, Hutten BA, Gagné C, Langslet G, McCrindle BW, Wiegman A, et al. Efficacy and safety of rosuvastatin therapy for children with familial hypercholesterolemia. Pediatric Cardiology 2010;55(11):1121-6.

\section{Braaskamp 2015a \{published data only\}}

Braaskamp MJ, Stefanutti C, Langslet G, Drogari E, Wiegmann A, Hounslow N, et al. Efficacy and safety of pitavastatin in children and adolescents at high future cardiovascular risk. Journal of Pediatrics 2015;167(2):338-43.

\section{Clauss 2005 \{published data only\}}

Clauss SB, Holmes KW, Hopkins P, Stein E, Cho M, Tate A, et al. Pediatrics Efficacy and safety of lovastatin therapy in adolescent girls with heterozygous familial hypercholesterolemia. Pediatrics 2005;116(3):682-8.

\section{Couture 1998 \{published data only\}}

Couture P, Brun LD, Szots F, Lelièvre M, Gaudet D, Després J$P$, et al. Association of specific LDL receptor gene mutations with differential plasma lipoprotein response to simvastatin in young French Canadian with heterozygous familial hypercholesterolemia. Arteriosclerosis Thrombosis and Vascular Biology 1998;18(6):1007-12.

\section{de Jongh 2002a \{published data only\}}

De Jongh S, Stalenhoef AF, Tuohy MB, Mercuri M, Bakker HD, Kastelein JJ. Efficacy, safety and tolerability of simvastatin in children with familial hypercholesterolaemia: rationale, design, and baseline characteristics. Clinical Biochemistry and Metabolism 2003;11(32):157-62.

de Jongh S, Lilien MR, op't Roodt J, Stroes ES, Bakker HD, Kastelein JJ. Early statin therapy restores endothelial function in children with familial hypercholesterolemia. Journal of the American College of Cardiology 2002;40(12):2117-21. []

* de Jongh S, Ose L, Szamosi T, Gagné C, Lambert M, Scott R, et al. Efficacy and safety of statin therapy in children with familial hypercholesterolemia: A randomized, doubleblind, placebo-controlled trial with simvastatin. Circulation 2002;106(17):2231-7.

de Jongh S, Stalenhoef AF, Tuohy MB, Mercuri M, Bakker HD, Kastelein JJ. Efficacy, safety and tolerability of simvastatin in children with familial hypercholesterolaemia. Clinical Drug Investigation 2002;22(8):533-40.

\section{Knipscheer 1996 \{published data only\}}

Knipscheer HC, Boelen CC, Kastelein JJ, van Diermen DE, Groenemeijer BE, van den Ende A, et al. Short-term efficacy and safety of pravastatin in 72 children with familial hypercholesterolemia. Pediatric Research 1996;39(5):867-71.

McCrindle 2003 \{published data only\} McCrindle BW, Ose L, Marais AD. Efficacy and safety of atorvastatin in children and adolescents with a familial hypercholesterolemia or severe hyperlipidemia: A multicenter, randomized, placebo-controlled trial. Journal of Pediatrics 2003;143(1):74-80.

Stein 1999 \{published data only\}

Stein EA, Illingworth DR, Kwiterovich Jr. PO, Liacouras CA, Siimes MA, Jacobson MS, et al. Efficacy and safety of lovastatin in adolescent males with heterozygous familial hypercholesterolemia. JAMA 1999;281(2):137-44.

\section{Wiegman 2004 \{published data only\}}

Wiegman A, Hutten BA, de Groot E, Rodenburg J, Bakker HD, Büller HR, et al. Efficacy and safety of statin therapy in children with familial hypercholesterolemia. JAMA 2004;292(3):331-7.

\section{References to studies excluded from this review}

Athyros 2002 \{published data only\}

Athyros VG, Papageorgiou AA, KOntopoulos AG. Longterm treatment with atorvastatin in adolescent males with heterozygous familial hypercholesterolemia. Atherosclerosis 2002;163(1):205-6

Braaskamp 2015b \{published data only\}

Braamskamp MJ, Kusters DM, Wiegmann A, Avis HJ, Wijburg FA Kastelein JJ, et al. Gonadal steroids, gonadotropins and DHEAS in young adults with familial hypercholesterolemia who had initiated statin therapy in childhood. Atherosclerosis 2015;241(2):427-32.

Braaskamp 2015c \{published data only\}

Braaskamp MJ, Langslet G, McCrindle BW, Cassiman D, Francis GA, Gagné C, et al. Efficacy and safety of rosuvastatin therapy in children and adolescents with familial hypercholesterolemia: Results from the CHARON study. Journal of Clinical Lipidology 2015;9(6):741-50.

\section{Carreau 2011 \{published data only\}}

Carreau V, Girardet JP, Bruckert E. Long-term follow-up of statin treatment in a cohort of children with familial hypercholesterolemia: Efficacy and tolerability. Pediatric Drugs 2011;13(4):267-75

\section{Chan 2016 \{published data only\}}

Chan DC, Pang J, Barrett PH, Sullivan DR, Mori TA, Burnett JR, et al. Effect of omega-3 fatty acid supplementation on arterial elasticity in patients with familial hypercholesterolaemia on statin therapy. Nutrition, Metabolism and Cardiovascular Diseases 2016;26(12):1140-5. [CENTRAL: 1247168; CRS: 5500050000000549; EMBASE: 613255561]

\section{Dirisamer 2003 \{published data only\}}

Dirisamer A, Hachemian N, Bucek RA, Wolf F, Reiter M, Widhalm K. The effect of low-dose simvastatin in children with familial hypercholesterolemia: a 1-year observation. European Journal of Pediatrics 2003;162(6):421-5. 


\section{Gandelman 2011 \{published data only\}}

Gandelman K, Glue P, Laskey R, Jones J, LaBadie R, Ose L. An eight-week trial investigating the efficacy and tolerability of atorvastatin for children and adolescents with heterozygous familial hypercholesterolemia. Pediatric Cardiology 2011;32(4):433-41.

\section{Harada-Shiba 2018 \{published data only\}}

Harada-Shiba M, Kastelein JJ, Hovingh K, Ray KK, Ohtake A, Arisaka $\mathrm{O}$, et al. Efficacy and safety of pitvastatin in children and adolescents with familial hypercholesterolemia in Japan and Europe. Journal of Atherosclerosis and Thrombosis 2018;25:422-429.

\section{Hedman 2003 \{published data only\}}

Hedman M, Neuvonen PJ, Neuvonen N, Antikainen M. Pharmacokinetics and pharmacodynamics of pravastatin in children with familial hypercholesterolemia. Clinical Pharmacology and Therapy 2003;74(2):178-85.

\section{Hedman 2005 \{published data only\}}

Hedman M, Matikainen T, Fohr A, Lappi M, Piippo S, Nuutinen M, et al. Efficacy and safety of pravastatin in children and adolescents with heterozygous familial hypercholesterolemia: A prospective clinical follow-up study. Journal of Clinical Endocrinology and Metabolism 2005;90(4):1942-52.

\section{Lambert 1996 \{published data only\}}

Lambert M, Lupien PJ, Gagne C, Levy E, Blaichman S, Langlois S, et al. Treatment of familial hypercholesterolemia in children and adolescents: Effect of lovastatin. Pediatrics 1996;97(5):619-28.

\section{Langslet 2016 \{published data only\}}

Langslet G, Breazna A, Drogari E. A 3-year study of atorvastatin in children and adolescents with heterozygous familial hypercholesterolemia. Journal of Clinical Lipidology 2016;10(5):1153-62.

\section{McCrindle 2002 \{published data only\}}

McCrindle BW, Helsden E, Cullen-Dean G, Conner WT. A randomized crossover trial of combination pharmacologic therapy in children with familial hyperlipidemia. Pediatric Research 2002;51(6):715-21.

\section{Raal 1997 \{published data only\}}

Raal FJ, Pitcher G, Rubinsztein DC, Lingenhel A, Utermann G. Statin therapy in a kindred with both apolipoprotein $B$ and low-density lipoprotein receptor gene defects. Atherosclerosis 1997;129(1):97-102.

\section{Sinzinger 2004 \{published data only\}}

Sinzinger H, O'Grady J. Professional athletes suffering from familial hypercholesterolemia rarely tolerate statin treatment because of muscular problems. British Journal of Clinical Pharmacology 2004;57(4):525-8.

\section{Stefanutti 1999 \{published data only\}}

Stefanutti C, Lucani G, Vivenzio A, Di Giacomo S. Diet only and diet plus simvastatin in the treatment of heterozygous familial hypercholesterolemia in childhood. Drugs Under Experimental and Clinical Research 1999;25(1):23-8.

Stein 1989 \{published data only\}

Stein EA. Treatment of familial hypercholesterolemia with drugs in children. Arteriosclerosis 1989;9(Suppl 1):1145-51.

\section{Stein 2016 \{published data only\}}

Stein EA, Dann EJ, Wiegmann A, Skovby F, Gaudet D, Sokal E, et al. A randomized, double-blind, placebo-controlled, multicenter, Cross-over study of rosuvastatin in children and adolescents (aged 6 to $<18$ years) with homozygous familial hypercholesterolemia (HOFH). JACC 2016;67(13):1855.

\section{Tada 2016 \{published data only\}}

Tada H, Kobayashi J, Kawashiri MA, Miashita K, Nohara A, Inazu $A$, et al. Changes in lipoprotein lipase and endothelial lipase mass in familial hypercholesterolemia during three-drug lipid-lowering combination therapy. Lipids in Health and Disease 2016;15:66

\section{Teramoto 2016 \{published data only\}}

Teramoto T, Kobayashi M, Tasaki H, Yagyu H, Higashikata T, Takagi Y, et al. Efficacy and safety of alirocumab in Japanese patients With heterozygous familial hypercholesterolemia or at high cardiovascular risk with hypercholesterolemia not adequately controlled with statins - ODYSSEY JAPAN Randomized Controlled Trial. Ciruculation Journal 2016;80(9):1980-7.

\section{van der Graaf 2006 \{published data only\}}

van der Graaf A, Nieman MC, Firth JC, Wolmarans KH, Marais AD, De GE. Efficacy and safety of fluvastatin in children and adolescents with heterozygous familial hypercholesterolemia. Acta Paediatrica 2006;95(11):1461-6.

\section{Additional references}

\section{Arambepola 2007}

Arambepola C, Farmer AJ, Perera R, Neil HA. Statin treatment for children and adolescents with heterozygous familial hypercholesterolaemia: A systematic review and meta-analysis. Atherosclerosis 2007;195(2):339-47.

\section{Avis 2007}

Avis HJ, Vissres EA, Stein FA, Wijburg MD, Trip JJP, Kastelein JJ, et al. A systematic review and meta-analysis of statin therapy in children with familial hypercholesterolemia. Arteriosclerosis Thrombosis and Vascular Biology 2007;27(8):1803-10.

\section{Backes 2003}

Backes JM, Howard PA. Association of HMG-CoA reductase inhibitors with neuropathy. Annals of Pharmacotherapy 2003;37(2):274-8.

\section{Bays 2006}

Bays H. Statin safety: An overview an assessment of the data 2005. American Journal of Cardiology 2006;97(8A):6C-26C. 


\section{Benn 2016}

Benn M, Watts GF, Tybjærg-Hansen A, Nordetsgaard BG. Mutations causative of familial hypercholesterolaemia: screening of 98098 individuals from the Copenhagen General Population Study estimated a prevalence of 1 in 217 . European Heart Journal 2016;37(17):1384-94.

\section{Besseling 2015}

Besseling J, Kastelein JJ, Defesche JC, Hutten BA, Hovingh GK. Association between familial hypercholesterolemia and prevalence of type 2 diabetes mellitus. JAMA 2015;313(10):358-61.

\section{Bradford 1991}

Bradford RH, Shear CL, Chremos AN, Dujovne C, Dowton M, Franklin FA, et al. Expanded clinical evaluation of lovastatin (EXCEL) study results. I. Efficacy in modifying plasma lipoproteins and adverse event profile in 8245 patients with moderate hypercholesterolemia. Archives of Internal Medicine 1991;151(1):43-9.

\section{Brass 2006}

Brass LM, Alberts MJ, Sparks L. National Lipid Association Statin Safety Task Force Neurology Expert Panel: An assessment of statin safety by neurologist. American Journal of Cardiology 2006;97(8A):86C-88C.

\section{Cenedella 1996}

Cenedella RJ. Cholesterol and cataracts. Survey of Opthalmology 1996;40(4):320-37.

\section{Chalasani 2004}

Chalasani N, Aljadhey H, Kesterson J, Murray MD, Hall SD. Patients with elevated liver enzymes are not at higher risk for statin hepatotoxicity. Gastroenterology 2004;126(5):1287-92.

\section{Chodick 2010}

Chodick G, Heymann AD, Flash S, Kokia E, Shalev V. Persistence with statins and incident cataract: a population-based historical cohort study. Annals of Epidemiology 2010;20(2):136-42.

\section{Chong 2004}

Chong PH, Boskovich A, Sevkovic N, Bartt RE. Statinassociated peripheral neuropathy: Review of the literature. Pharmacotherapy 2004;24(9):1194-203.

\section{Cohen 2006}

Cohen DE, Anania FA, Chalasani N. An assessment of statin safety by hepatologists. American Journal of Cardiology 2007;8(Suppl 1):S77-S81.

\section{Daniels 2008}

Daniels SR, Greer FR, Committee on Nutrition. Lipid screening and cardiovascular health in children. Pediatrics 2008;122(1):198-208.

\section{de Denus 2004}

de Denus S, Spinler SA, Miller K, Peterson AM. Statins and live toxicity: a meta-analysis. Pharmacotherapy 2004;24(5):584-91.

\section{de Jongh 2002b}

de Jongh S, Lilien MR, op't Roodt J, Stroes ES, Bakker HD, Kastelein JJ. Early statin therapy restores endothelial function in children with familial hypercholesterolemia. Journal of the American College of Cardiology 2002;40(12):2117-21.

\section{Descamps 2011}

Descamps OS, Tenoutasse S, Stephenne X, Gies I, Beauloye V, Lebrethon MC, et al. Management of familial hypercholesterolemia in children and young adults: consensus paper developed by a panel of lipidologists, cardiologists, paediatricians, nutritionists, gastroenterologists, general practitioners and a patient organization. Atherosclerosis 2012;218(2):272-80.

\section{Fong 2012}

Fong DS, Poon KY. Recent statin use and cataract surgery. American Journal of Opthalmology 2012;153(2):222-8.

\section{Futema 2013}

Futema M, Whittall RA, Kiley A, Steel LK, Cooper JA, Badmus E, et al. Analysis of the frequency and spectrum on mutation recognised to cause familial hypercholesterolaemia in routine clinical practise in a UK specialist hospital clinic. Atherosclerosis 2013;229(1):161-8.

\section{Futema 2015}

Futema M, Shah S, Cooper JA, Li K, Whittall RA, Sharifi M, et al. Refinement of variant selection for the LDL cholesterol genetic risk score in the diagnosis of the polygenic form of clinical familial hypercholesterolemia and replication in samples from 6 countries. Clinical Chemistry 2015;61(1):231-8.

\section{Goldberg 2011}

Goldberg AC, Hopkins PN, Toth PP, Ballantyne CM, Rader DJ, Robinson JG, et al. Familial hypercholesterolemia: screening, diagnosis and management of pediatric and adult patients: clinical guidance from the National Lipid Association Expert Panel on Familial Hypercholesterolemia. Journal of Clinical Lipidology 2011;5(3 Suppl):S1-S8.

\section{Goldstein 1979}

Goldstein JL, Helgeson JA, Brown MS. Inhibition of cholesterol synthesis with compactin renders growth of cultured cells dependent on the low density lipoprotein receptor. Journal of Biological Chemistry 1979;254(12):5403-9.

\section{Goldstein 1990}

Goldstein JL, Brown MS. Regulation of the mevalonate pathway. Nature 1990;343(6257):425-30.

\section{Goldstein 1995}

Goldstein JL, Hobbs HH, Brown MS. Familial hypercholesterolemia. In: Scriver CR, Beaudet AL, Sly WS, Valle D editor(s). The Metabolic Bases of Inherited Diseases. 7th Edition. New York, NY: McGraw-Hill Book Co, 1995:1981-2030.

\section{Golomb 2013}

Golomb BA. The importance of monitoring adverse events in statin, and other, clinical trials. Clinica Investigation 2013;3(10):913-6. 


\section{Graham 2005}

Graham CA, Mcllhatton BP, Kirk CW, Beattie ED, Lyttle K, Hart P, et al. Genetic screening protocol for familial hypercholesterolemia which includes splicing defects gives an improved mutation detection rate. Atherosclerosis 2005;182(2):331-40.

\section{Harris 1995}

Harris ML, Bron AJ, Brown NAkeech AC, Wallendszus KR, Armitage JM, MacMahon S, et al. Absence of effect of simvastatin on the progression of lens opacitis in a randomised placebo controlled study. Oxford Cholesterol Study Group. Bristish Journal of Opthalmology 1995;79(11):996-1002.

\section{Heath 1999}

Heath KE, Gudnason V, Humphries SE, Seed M. The type of mutation in the low density lipoprotein receptor gene influences the cholesterol-lowering response of the HMG$\mathrm{CoA}$ reductase inhibitor simvastatin in patients with heterozygous familial hypercholesterolemia. Atherosclerosis 1999;143(1):41-54.

\section{Higgins 2003}

Higgins JP, Thompson SG, Deeks JJ, Altman DG. Measuring inconsistency in meta-analyses. BMJ 2003;327(7414):557-60.

\section{Higgins 2011a}

Higgins JP, Deeks JJ, editor(s). Chapter 7: Selecting studies and collecting data. In: Higgins JPT, Green S editor(s). Cochrane Handbook for Systematic Reviews of Interventions Version 5.1.0 (updated March 2011). The Cochrane Collaboration, 2011. Available from handbook.cochrane.org.

\section{Higgins 2011b}

Higgins JP, Altman DG, editor(s). Chapter 8: Assessing risk of bias in included studies. In: Higgins JPT, Green S, editor(s). Cochrane Handbook for Systematic Reviews of Interventions Version 5.1.0 [updated March 2011]. The Cochrane Collaboration, 2011. Available from www.cochranehandbook.org.

\section{Hippisley-Cox 2010}

Hippisley-Cox, Coupland C. Unintended effects of statins in men and women in England and Wales: population based cohort study using the QResearch database. BMJ 2010;340:c2197.

\section{Hoffmann 2002}

Hoffmann U, Dirisamer A, Heher S, Kostner K, Widhalm K, Neunteufl T. Relation of flow-mediated vasodilatation and coronary arterial calcium in young patients with heterozygous familial hypercholesterolemia. American Journal of Cardiology 2002;90(1):70-3.

\section{Humphries 2006a}

Humphries SE, Cranston T, Allen M, Middleton-Price H, Fernandez MC, Senior V, et al. Mutational analysis in UK patients with a clinical diagnosis of familial hypercholesterolemia: relationship with plasma lipid traits, heart disease risk and utility in relative tracing. Journal of Molecular Medicine (Berl) 2006;84(3):203-14.

\section{Humphries 2006b}

Humphries SE, Whittall RA, Hubbart CS, Maplebeck S, Cooper JA, Soutar A, et al. Genetic causes of Familial Hypercholesterolaemia in UK patients: Relation to plasma lipid levels and coronary heart disease risk. Journal of Medical Genetics 2006;43(12):943-9.

\section{lacocca 2018}

lacocca MA, Chora JR, Carrié A, Freiberger T, Leigh SE, Defesche JC, et al. ClinVar database of global familial hypercholesterolemia-associated DNA variants. Human Mutation 2018;39(11):2018.

\section{Joy 2009}

Joy TR, Hegele RA. Narrative Review: statin-related myopathy. Annals of Internal Medicine 2009;150(12):858-68.

\section{Joyce 2017}

Joyce NR, Zachariah JP, Eaton CB, Trivedi AN, Wellenius GA. Statin use and the risk of type 2 diabetes mellitus in children adolescents. Acta Pediatrica 2017;17(5):515-22.

\section{Jüni 2001}

Jüni P, Altman DG, Egger M. Assessing the quality of controlled clinical trials. BMJ 2001;323(7303):42-6.

\section{Khera 2016}

Khera A, Won HH, Peloso GM, Lawson KS, Bartz TM, Deng X, et al. Diagnostic yield and clinical utility of sequencing familial hypercholesterolemia genes in patients with severe hypercholesterolemia. Journal American College of Cardiology 2016;67(22):2578-89.

\section{Koeijvoets 2005}

Koeijvoets KC, Rodenburg J, Hutten BA, Wiegman A, Kastelein JJ, Sijbrands EJ. Low-density lipoprotein receptor genotype and response to pravastatin in children with familial hypercholesterolemia: substudy of an intima-media thickness trial. Circulation 2005;112(20):3168-73.

\section{Kotze 1993}

Kotze MJ, De Villiers WJ, Steyn K, Kriek JA, Marais AD, Langenhoven E, et al. Phenotypic variation among familial hypercholesterolemics heterozygous for either one of two Afrikaner founder LDL receptor mutations. Arteriosclerosis and Thrombosis 1993;13(10):1460-8.

\section{Kusters 2014}

Kusters DM, Avis HJ, de Groot E, Wijburg FA, Kastelein JJ, Wiegmann A, et al. Ten-year follow-up after initiation of statin therapy in children with familial hyeprcholesterolemia. JAMA 2014;312(10):1055-7.

\section{Kwiterovich 1974}

Kwiterovich PO Jr, Fredrikson DS, Levy RI. Familial hypercholesterolemia (one form of familial type II hyperlipoproteinemia). A study of its biochemical, genetic and clinical presentation in childhood. Journal of Clinical Investigation 1974;53(5):1237-49. 


\section{Law 2006}

Law M, Rudnicka AR. Statin safety: A systematic review. American Journal of Cardiology 2006;97(8A):52C-60C.

\section{Leigh 2016}

Leigh S, Futema M, Taylor-Beadling A, Williams M, den Dunnen JT, Humphries SE. The UCL low-density lipoprotein receptor gene variant database: pathogenicity update. Journal of Medical Genetics 2016;54(4):217-23.

\section{Leonard 1976}

Leonard JV, Fosbrooke AS, Lloyd JK, Wolff OH. Screening for familial hyper-beta-lipoproteinemia in children in hospital. Archives of Diseases in Children 1976;51(11):842-7.

\section{Leuschen 2013}

Leuschen J, Mortensen EM, Frei CR, Mansi EA, Panday V, Mansi I. Association of statin use with cataracts: a propensity scorematched analysis. JAMA Opthalmolology 2013;131(11):1427-34.

\section{Mabuchi 1989}

Mabuchi H, Koizumi J, Shimizu M, Takeda R. Development of coronary heart disease in familial hypercholesterolemia. Circulation 1989;79(2):225-32.

\section{McCrindle 2007}

McCrindle BW, Urbina EM, Dennison BA, Jacobson MS, Steinberger J, Rocchini AP, et al. Drug therapy of high-risk lipid abnormalities in children and adolescents: a scientific statement from the American Heart Association Atherosclerosis, Hypertension, and Obesity in Youth Committee, Council of Cardiovascular Disease in the Young, with the Council on Cardiovascular Nursing. Circulation 2007;115(14):1948-67.

\section{McCrindle 2012}

McCrindle BW. Familial hypercholesterolemia in children and adolescents. Current Opinion in Lipidology 2012;23(6):525-31.

\section{McKenney 2006}

McKenney JM, Davidson MH, Jacobson TA, Guyton JR. Final conclusions and recommendations of the National Lipid Association Statin Safety Task Force. American Journal of Cardiology 2006;97(8A):89C-94C.

\section{Miltiadous 2005}

Miltiadous G, Xenophontos S, Bairaktari E, Ganotakis M, Cariolou M, Elisaf M. Genetic and environmental factors affecting the response to statin therapy in patients with molecularly defined familial hypercholesterolaemia. Pharmagogenetic Genomics 2005;15(4):219-25.

\section{Myant 1993}

Myant NB. Familial defective apolipoprotein B-100: A review, including some comparisons with familial hypercholesterolaemia. Atherosclerosis 1993;104(1-2):1-18.

\section{Navarese 2013}

Navarese EP, Buffon A, Andreotti F, Kozinski M, Welton N, Fabiszak T, et al. Meta-anaysis of impact of different types and doses of statins on new-onset diabetes mellitus. American Journal of Cardiology 2013;111(8):1123-30.

\section{NICE 2008}

National Institute of Clinical Excellence. Identification and management of familial hypercholesterolaemia - clinical guideline CG71. http://www.nice.org.uk/nicemedia/pdf/ CG071NICEGuideline.pdf (accessed 01 October 2013).

\section{Nordestgaard 2013}

Nordestgaard BG, Chapman MJ, Humphries SE, Ginsberg HN, Masana I, Descamps OS, et al. Familial hypercholesterolaemia is underdiagnosed and undertreated in the general population: guidance for clinicians to prevent coronary heart disease: consensus statement of the European Atherosclerosis Society. European Heart Journal 2013;34(45):3478-90.

\section{O'Connor 1990}

O'Connor P, Feely J, Shepherd J. Lipid lowering drugs. BMJ 1990;300(6725):667-72.

\section{Pang 2016}

Pang J, Landsberg PJ, Watts GF. International developments in the care of familial hypercholesterolemia: Where now and where to next?. Journal of Atherosclerosis and Thrombosis 2016;23(5):505-19.

\section{Pasternak 2002}

Pasternak RC, Smith SC, Bairey-Merz CN, Grundy SM, Cleeman JI, Lenfant C, et al. ACC/AHA/NHLBI Clinical advisory on the use and safety of statins. Circulation 2002;106(8):1024-8.

\section{Pedersen 1996}

Pedersen TR, Berg K, Cook TJ, Faergeman O, Haghfelt T, Kjekshus J, et al. Safety and tolerability of cholesterol lowering with simvastatin during 5 years in the Scandinavian Simvastatin Survival Study. Archives of Internal Medicine 1996;156(18):2085-92.

\section{Poustie 2001}

Poustie VJ, Rutherford P. Dietary treatment for familial hypercholesterolaemia. Cochrane Database of Systematic Reviews 2001, Issue 2. [DOI: 10.1002/14651858.CD001918]

\section{Sattar 2010}

Sattar N, Preiss D, Murray HM, Welsh P, Buckley BM, de Craen AJ, et al. Statins and risk of incident diabetes: a collaborative meta-analysis of randomised statin trials. Lancet 2010;375(9716):735-42.

\section{SIGN 2007}

Scottish Intercollegiate Guidelines Network. Risk estimation and the prevention of cardiovascular disease. www.sign.ac.uk/ pdf/sign97.pdf (accessed 01 October 2013).

\section{Sjouke 2015}

Sjouke B, Kusters DM, Besseling J, Defesche JC, Sijbrands EJ, Roeters van Lennep JE, et al. Homozygous autosomal dominant hypercholesterolaemia in the Netherlands: prevalence, genotype-phenotype relationship, and clinical outcome. European Heart Journal 2015;36(9):560-5. 


\section{Skoumas 2014}

Skoumas J, Liontou C, Chrysohoou C, Masoura C, Aznaouridis K, Pitsavos $C$, et al. Statin therapy and risk of diabetes in patients with heterozygous familial hypercholesterolemia or familial combined hyperlipidemia. Atherosclerosis 2014;237(1):140-5.

\section{Staffa 2002}

Staffa JA, Chang J, Green L. Cerivastatin and reports of fatal rhabdomyolysis. New England Journal of Medicine 2002;346(7):539-40.

\section{Starr 2008}

Starr B, Hadfiled SG, Hutten BA, Landsberg P, Leren TP, Damgaard D, et al. Development of sensitive and specific age- and gender-specific low-density lipoprotein cholesterol cutoffs for diagnosis of first-degree relatives with familial hypercholesterolaemia in cascade testing. Clinical Chemistry and Laboratory Medicine 2008;46(6):791-803.

\section{Sullivan 2012}

Sullivan DR, Hamilton-Craig I, van Bockxmeer F, Watts GF, CSANZ Cardiac Genetics Diseases Council Writing Group. INTERIM guidelines for the diagnosis and management of familial hypercholesterolaemia. Heart Lung and Circulation 2012;21(3):159-62.

\section{Sun 1998}

Sun XM, Patel D, Knight BL, Soutar AK. Influence of genotype at the low density lipoprotein (LDL) receptor gene locus on the clinical phenotype and response to lipid-lowering drug therapy in heterozygous familial hypercholesterolemia. The Familial Hypercholesterolaemia Regression Study Group. Atherosclerosis 1998;136(1):175-85.

\section{Swerdlow 2015}

Swerdlow DI, Presii D, Kuchenbaecker KB, Holmes MV, Engmann JE, Shah T, et al. HMG-coenzyme A reductase inhibition, type 2 diabetes, and bodyweight: evidence from genetic analysis and randomised trials. Lancet 2015;385(9965):351-61.

\section{Talmud 2013}

Talmud PJ, Shah S, Whittall R, Futema M, Howard P, Cooper JA, et al. Use of low-density lipoprotein cholesterol gene score to distinguish patients with polygenic and monogenic familial hypercholesterolaemia: a case-control study. Lancet 2013;381(9874):1293-1301.

\section{Tonstad 1996}

Tonstad S, Joakimsen O, Stensland-Bugge E, Leren TP, Ose L, Russell D, et al. Risk factors related to carotid intimamedia thickness and plaque in children with familial hypercholesterolemia and control subjects. Arteriosclerosis, Thrombosis, and Vascular Biology 1996;16(8):984-91.

\section{Umans 2002}

Umans-Eckenhausen MA, Sijbrands EJ, Kastelein JJ, Defesche JC. Low-density lipoprotein receptor gene mutations and cardiovascular risk in a large genetic cascade screening population. Circulation 2002;106(24):3031-6.

\section{van der Graaf 2011}

van der Graaf A, Avis HJ, Kusters DM, Vissers MN, Hutten BA, Defesche JC, et al. Molecular basis of autosomal dominant hypercholesterolemia. Circulation 2011;123(11):1167-73.

\section{Vlahos 2014}

Vlahos AP, Naka KK, Bechlioulis A, Theoharis P, Vakalis K, Moutzouri E, et al. Endothelial dysfunction, but not structural atherosclerosis, is evident early in children with heterozygous familial hypercholesterolemia. Pediatric Cardiology 2014;35(1):63-70.

\section{Vohl 2002}

Vohl MC, Szots F, Leliévre M, Lupien PJ, Bergeron J, Gagné C, et al. Influence of LDL receptor gene mutation and apo E polymorphis on liporpotein response to simvastatin treatment among adolescents with heterozygous familial hypercholesterolemia. Atherosclerosis 2002;160(2):361-8.

\section{Vuorio 2001}

Vuorio AF, Aalto-Setälä K, Koivisto UM, Turtola H, Nissen H, Kovanen PT, et al. Familial hypercholesterolaemia in Finland: Common, rare and mild mutations of the LDL receptor and their clinical consequences. Annals of Medicine 2001;33(6):410-21.

\section{Vuorio 2013}

Vuorio A, Docherty KF, Humphries SE, Kuoppala J, Kovanen PT. Statin treatment of children with familial hypercholesterolemia - trying to balance incomplete evidence of long-term safety and clinical accountability: Are we approaching a consensus?. Atherosclerosis 2013;226(2):315-20.

\section{Vuorio 2016}

Vuorio A, Strandberg T, Schneider WJ, Kovanen PT. Statins and new-onset diabetes mellitus - a risk lacking in familial hypercholesterolaemia. Journal of Internal Medicine 2016;279(4):358-61.

\section{Wald 2016}

Wald DS, Bestwick JP, Morris JK, Whyte K, Jenkins L, Wald NJ. Child-parent familial hypercholesterolemia screening in primary care. New England Journal of Medicine 2016;375(17):1628-37.

\section{Wray 1996}

Wray R, Neil H, Rees J. Screening for hyperlipidaemia in childhood. Recommendations of the British Hyperlipidaemia Association. Journal of Royal College of Physicians London 1996;30(2):115-8.

\section{References to other published versions of this review Vuorio 2010}

Vuorio A, Kuoppala J, Kovanen PT, Humphries SE, Strandberg T, Tonstad S, et al. Statins for children with familial hypercholesterolemia. Cochrane Database of Systematic Reviews 2010, Issue 7. [DOI: 10.1002/14651858.CD006401.pub2] 


\section{Vuorio 2014}

Vuorio A, Kuoppala J, Kovanen PT, Humphries SE, Tonstad S, Wiegman A, Drogari E. Statins for children with familial hypercholesterolemia. Cochrane Database of Systematic Reviews 2014, Issue 7. [DOI: 10.1002/14651858.CD006401.pub3]

\section{Vuorio 2017}

Vuorio A, Kuoppala J, Kovanen PT, Humphries SE, Tonstad S, Wiegman A, et al. Statins for children with familial hypercholesterolemia. Cochrane Database of Systematic Reviews 2017, Issue 7. [DOI: 10.1002/14651858.CD006401.pub3]

* Indicates the major publication for the study

CHARACTERISTICS OF STUDIES

Characteristics of included studies [ordered by study ID]

Avis 2010

$\begin{array}{ll}\text { Methods } & \text { * Design: RCT } \\ & \text { * Randomization stratified by center } \\ & \text { * Blinding: double } \\ & \text { * Concealment of allocation: nr } \\ & \text { * Setting: } 20 \text { centers } \\ & \text { * Country: Netherlands, Canada, Norway, USA } \\ & \text { * Follow-up: } 12 \text { weeks }\end{array}$

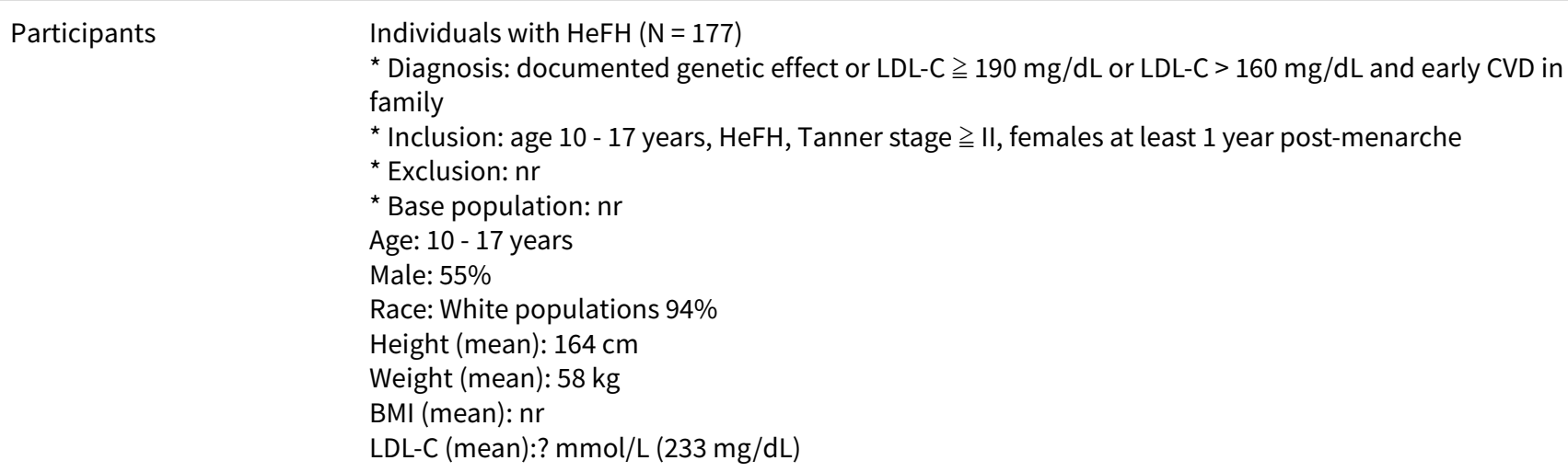

\section{Risk of bias}

Bias Authors' judgement Support for judgement


Avis 2010 (Continued)

Random sequence genera- Unclear risk Described as stratified but randomization procedure not described. tion (selection bias)

\begin{tabular}{lll}
\hline $\begin{array}{l}\text { Allocation concealment } \\
\text { (selection bias) }\end{array}$ & Unclear risk & $\mathrm{nr}$ \\
\hline $\begin{array}{l}\text { Blinding (performance } \\
\text { bias and detection bias) }\end{array}$ & Low risk & Double blind \\
All outcomes &
\end{tabular}

\begin{tabular}{|c|c|c|}
\hline $\begin{array}{l}\text { Incomplete outcome data } \\
\text { (attrition bias) } \\
\text { All outcomes }\end{array}$ & Low risk & $\begin{array}{l}\text { Compliance: } 87 \% \\
\text { Dropout: } 2 \% \\
\text { Losses to follow-up: } 1 \% \\
\text { Missing from analysis: } 1 \%\end{array}$ \\
\hline $\begin{array}{l}\text { Selective reporting (re- } \\
\text { porting bias) }\end{array}$ & Unclear risk & No indication to suspect selective reporting. \\
\hline
\end{tabular}

Braaskamp 2015a

\begin{tabular}{ll}
\hline Methods & * Design: RCT \\
& * Randomization stratified by age and baseline LDL-C \\
& * Blinding: double \\
& * Concealment of allocation: $\mathrm{nr}$ \\
& * Setting: 10 centers \\
& * Country: Netherlands, Greece, Norway, Italy, Spain, France \\
& * Follow-up: 12 weeks \\
\hline
\end{tabular}

\section{Participants}

Individuals with $\mathrm{HeFH}(\mathrm{N}=103)$

* Diagnosis: documented genetic effect or LDL-C $\geqq 160 \mathrm{mg} / \mathrm{dL}$ or LDL-C $>130 \mathrm{mg} / \mathrm{dL}$ and male, early CVD in family, HDL-C $<45 \mathrm{mg} / \mathrm{dL}, \mathrm{TG}>150 \mathrm{mg} / \mathrm{dL}$, lipoprotein(a) $>75 \mathrm{nmol} / \mathrm{L}$, type 2 diabetes mellitus diagnosed and blood pressure $>95$ th percentile for age and height.

* Inclusion: age 6 - 17 years, HeFH

* Exclusion: $\mathrm{nr}$

* Base population: $\mathrm{nr}$

Age: 6 - 17 years

Male: $45 \%$

Height (mean): $148 \mathrm{~cm}$

Weight (mean): $44 \mathrm{~kg}$

BMI (mean): $19.1 \mathrm{~kg} / \mathrm{m}^{2}$

LDL-C (mean): $232 \mathrm{mg} / \mathrm{dL}$

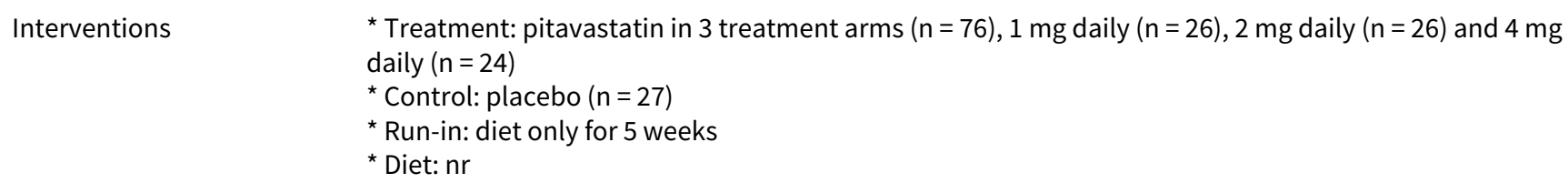

LDL-C (SD for mean percentage change not reported)
TC (SD for mean percentage change not reported)
HDL-C (SD for mean percentage change not reported)
TG (SD for mean percentage change not reported)
ASAT
ALAT
CK
Myopathy: myalgia


Braaskamp 2015a (Continued)

Adverse events: (adverse event not reported separately for the treatment groups)

Notes No indication to suspect selective reporting.

\section{Risk of bias}

\begin{tabular}{|c|c|c|}
\hline Bias & Authors' judgement & Support for judgement \\
\hline $\begin{array}{l}\text { Random sequence genera- } \\
\text { tion (selection bias) }\end{array}$ & Unclear risk & nr; multicenter study, central randomization assumed. \\
\hline $\begin{array}{l}\text { Allocation concealment } \\
\text { (selection bias) }\end{array}$ & Unclear risk & $\mathrm{nr}$ \\
\hline $\begin{array}{l}\text { Blinding (performance } \\
\text { bias and detection bias) } \\
\text { All outcomes }\end{array}$ & Low risk & Double blind \\
\hline $\begin{array}{l}\text { Incomplete outcome data } \\
\text { (attrition bias) } \\
\text { All outcomes }\end{array}$ & Low risk & $\begin{array}{l}\text { Compliance: } \mathrm{nr} \\
\text { Dropout: } 3 \% \\
\text { Losses to follow-up: } 0 \% \\
\text { Missing from analysis: } 0 \%\end{array}$ \\
\hline $\begin{array}{l}\text { Selective reporting (re- } \\
\text { porting bias) }\end{array}$ & Unclear risk & No indication to suspect selective reporting. \\
\hline
\end{tabular}

Clauss 2005

\begin{tabular}{|c|c|}
\hline Methods & $\begin{array}{l}\text { * Design: RCT } \\
\text { * Randomization process: } \mathrm{nr} \\
\text { * Blinding: double } \\
\text { * Concealment of allocation: by randomized numbers } \\
\text { * Setting: } 12 \text { medical centers } \\
\text { * Country: USA } \\
\text { * Follow-up: } 4 \text { and } 24 \text { weeks }\end{array}$ \\
\hline Participants & $\begin{array}{l}\text { * Participants with HeFH (N=54) } \\
\text { * Diagnosis: } 1 \text { parent with FH, LDL-C > 4.1mmol/L } \\
\text { * Inclusion: age } 10-17 \text { years; female; LDL-C } 4.1-10.3 \mathrm{mmol} / \mathrm{L} \text { on diet; TG < } 4.0 \mathrm{mmol} / \mathrm{L} \text {; postmenarchal > } \\
1 \text { year } \\
\text { * Exclusion: pregnancy; under/overweight; HoFH; dyslipidemia I, III-V; DM, hypothyroidism; renal disor- } \\
\text { der; certain medication (immunosuppressants, corticosteroids, cytochrome P-450 inhibitors) } \\
\text { * Base population: unclear; } 81 \text { individuals were screened } \\
\text { * Age: } 11-18 \text { years } \\
\text { * Male: } 0 \% \\
\text { * Race: } \mathrm{nr} \\
\text { * Height (mean): } 164 \mathrm{~cm} \\
\text { * Weight (mean): } 60 \mathrm{~kg} \\
\text { * BMI (mean): } 23 \mathrm{~kg} / \mathrm{m}^{2} \\
\text { * LDL-C (mean): } 5.5 \mathrm{mmol} / \mathrm{L}\end{array}$ \\
\hline Interventions & $\begin{array}{l}\text { * Intervention: lovastatin } 40 \mathrm{mg} \text { daily; started with } 20 \mathrm{mg} \text { for } 4 \text { weeks, then increased to } 40 \mathrm{mg}(\mathrm{n}=35) \\
\text { * Control: placebo }(\mathrm{n}=19) \\
\text { * Drugs discontinued } 6 \text { - } 8 \text { weeks before randomization; diet/placebo run-in for } 4 \text { weeks } \\
\text { * AHA step } 1 \text { diet or similar instruction at baseline }\end{array}$ \\
\hline
\end{tabular}


Clauss 2005 (Continued)

Outcomes

LDL-C: enzymatic method, calculated Friedewald's formula

TC: enzymatic method

HDL-C: heparin-manganese chloride method

TG: enzymatic method

Notes

\section{Risk of bias}

\begin{tabular}{|c|c|c|}
\hline Bias & Authors' judgement & Support for judgement \\
\hline $\begin{array}{l}\text { Random sequence genera- } \\
\text { tion (selection bias) }\end{array}$ & Low risk & Randomization process by randomized numbers. \\
\hline $\begin{array}{l}\text { Allocation concealment } \\
\text { (selection bias) }\end{array}$ & Unclear risk & $\mathrm{nr}$ \\
\hline $\begin{array}{l}\text { Blinding (performance } \\
\text { bias and detection bias) } \\
\text { All outcomes }\end{array}$ & Low risk & Double blind \\
\hline $\begin{array}{l}\text { Incomplete outcome data } \\
\text { (attrition bias) } \\
\text { All outcomes }\end{array}$ & Low risk & $\begin{array}{l}\text { Compliance: } \mathrm{nr} \\
\text { Dropout: } 6 \% \\
\text { Losses to follow-up: } 6 \% \\
\text { Missing from analysis: } 0 \%\end{array}$ \\
\hline $\begin{array}{l}\text { Selective reporting (re- } \\
\text { porting bias) }\end{array}$ & Unclear risk & No indication to suspect selective reporting. \\
\hline
\end{tabular}

Couture 1998

\begin{tabular}{|c|c|}
\hline Methods & 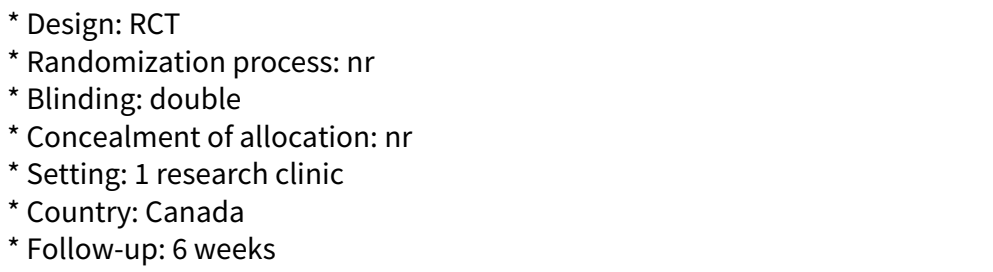 \\
\hline Participants & 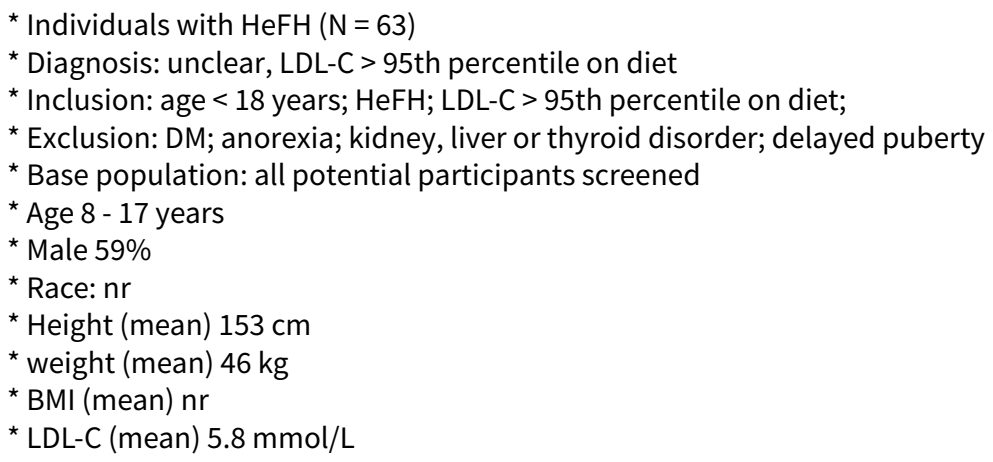 \\
\hline Interventions & $\begin{array}{l}\text { * Treatment: simvastatin } 20 \text { mg daily }(n=47) \\
\text { * Control: placebo }(n=16) \\
\text { * Run-in: placebo } 4 \text { weeks } \\
\text { * Diet: AHA phase I, dietary counselling throughout the trial }\end{array}$ \\
\hline
\end{tabular}

Statins for children with familial hypercholesterolemia (Review) 
Couture 1998 (Continued)

Outcomes
LDL-C: enzymatic method, calculated Friedewald's formula

TC: enzymatic method

HDL-C: heparin-manganese chloride method

TG: enzymatic method

\section{Notes}

\section{Risk of bias}

\begin{tabular}{lll}
\hline Bias & Authors' judgement & Support for judgement \\
\hline $\begin{array}{l}\text { Random sequence genera- } \\
\text { tion (selection bias) }\end{array}$ & Unclear risk & Described as randomized, process not reported. \\
\hline $\begin{array}{l}\text { Allocation concealment } \\
\text { (selection bias) }\end{array}$ & Unclear risk & $\mathrm{nr}$ \\
\hline $\begin{array}{l}\text { Blinding (performance } \\
\text { bias and detection bias) } \\
\text { All outcomes }\end{array}$ & Low risk & Double blind \\
\hline $\begin{array}{l}\text { Incomplete outcome data } \\
\text { (attrition bias) }\end{array}$ & Unclear risk & $\begin{array}{l}\text { Compliance: nr } \\
\text { All outcomes }\end{array}$ \\
& & $\begin{array}{l}\text { Dropout: nr } \\
\text { Losses to follow-up: } 0 \%\end{array}$ \\
\hline $\begin{array}{l}\text { Selective reporting (re- } \\
\text { porting bias) }\end{array}$ & Unclear risk & No indication to suspect selective reporting. \\
\hline
\end{tabular}

de Jongh 2002a

$\begin{array}{ll}\text { Methods } & \text { * Design: RCT } \\ & \text { * } \text { Randomization process: } \mathrm{nr} \\ & \text { * } \text { Blinding: double } \\ & \text { * } \text { Concealment of allocation: } \mathrm{nr} \\ & \text { * Setting: } 7 \text { countries, } 9 \text { medical centers } \\ & \text { * Country: Canada, Costa Rica, France, Netherlands, New Zealand, Norway } \\ & \text { * } \text { Follow-up: } 24 \text { and } 48 \text { weeks }\end{array}$

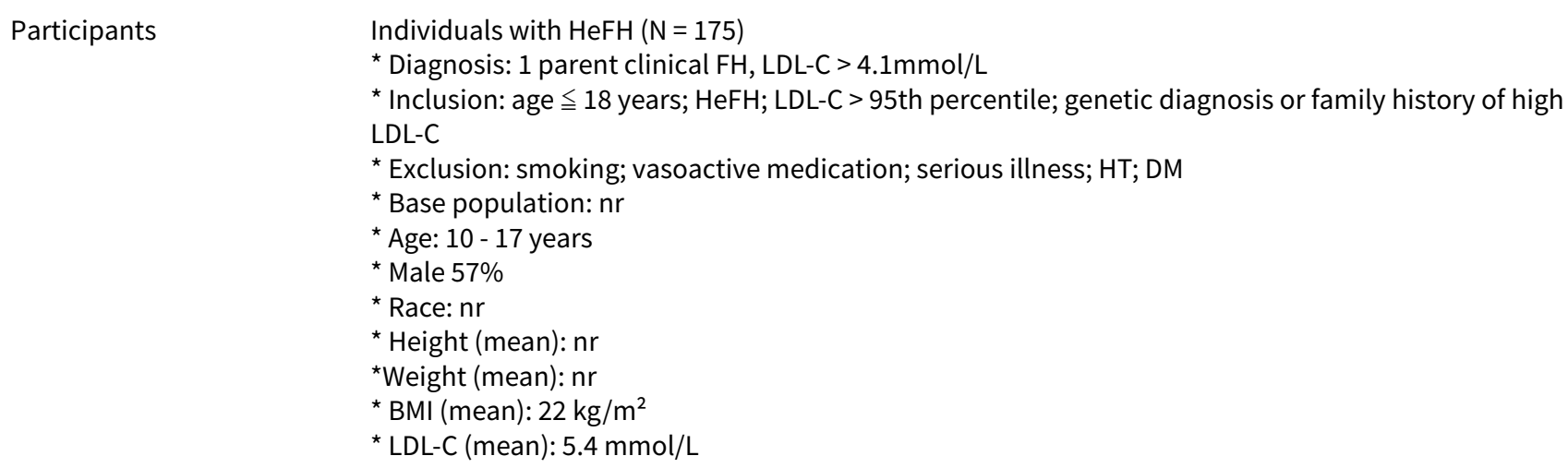


de Jongh 2002a (Continued)

${ }^{*}$ Run-in: diet + placebo for 4 weeks

* Diet: $\mathrm{nr}$

Outcomes
TC: : enzymatic method
HDL-C: enzymatic method
TG: enzymatic method
FMD: on brachial artery by ultrasonography, method described (on subset of Dutch group)
CRP method: $\mathrm{nr}$
ASAT method: $\mathrm{nr}$
ALAT method: $\mathrm{nr}$
CK method: $\mathrm{nr}$
Puberty: Tanner staging by clinical examination
Myopathy: criteria nr
Adverse events: drug-related clinical adverse event, criteria unclear, method: $\mathrm{nr}$

Notes

\section{Risk of bias}

\begin{tabular}{|c|c|c|}
\hline Bias & Authors' judgement & Support for judgement \\
\hline $\begin{array}{l}\text { Random sequence genera- } \\
\text { tion (selection bias) }\end{array}$ & Unclear risk & Described as randomized, process not reported. \\
\hline $\begin{array}{l}\text { Allocation concealment } \\
\text { (selection bias) }\end{array}$ & Unclear risk & $\mathrm{nr}$ \\
\hline $\begin{array}{l}\text { Blinding (performance } \\
\text { bias and detection bias) } \\
\text { All outcomes }\end{array}$ & Low risk & Double blind \\
\hline $\begin{array}{l}\text { Incomplete outcome data } \\
\text { (attrition bias) } \\
\text { All outcomes }\end{array}$ & Low risk & $\begin{array}{l}\text { Compliance: } \mathrm{nr} \\
\text { Dropout: } 6 \% \\
\text { Losses to follow-up: } 6 \% \\
\text { Missing from analysis: } 6 \%\end{array}$ \\
\hline $\begin{array}{l}\text { Selective reporting (re- } \\
\text { porting bias) }\end{array}$ & Unclear risk & No indication to suspect selective reporting. \\
\hline
\end{tabular}

\section{Knipscheer 1996}

\begin{tabular}{|c|c|}
\hline Methods & $\begin{array}{l}\text { * Design: RCT } \\
\text { * Randomization: stratified } \\
\text { * Blinding: double } \\
{ }^{*} \text { Concealment of allocation: } \mathrm{nr} \\
{ }^{*} \text { Setting: no. of medical centers: } \mathrm{nr} \\
{ }^{*} \text { Country: Netherlands } \\
{ }^{*} \text { Follow-up: } 12 \text { weeks }\end{array}$ \\
\hline Participants & $\begin{array}{l}\text { Individuals with } \mathrm{HeFH}(\mathrm{N}=72) \\
{ }^{*} \text { Diagnosis: } \mathrm{LDL}-\mathrm{C}>95 \mathrm{th} \text { percentile on diet and } \mathrm{HC} \text { or early AS in family } \\
{ }^{*} \text { Inclusion: age } 8-16 \text { years; HeFH } ~ \mathrm{LDL}-\mathrm{C}>95 \mathrm{th} \% \text { tile on diet; } \mathrm{HC} \text { or early AS in family } \\
{ }^{*} \text { Exclusion: major surgery within } 3 \text { months; drugs interfering with lipid metabolism; liver or renal dys- } \\
\text { function } \\
{ }^{\star} \text { Base population: } \mathrm{nr} \\
\text { Age: } 8 \text { - } 16 \text { years }\end{array}$ \\
\hline
\end{tabular}


Knipscheer 1996 (Continued)

\author{
Male: $35 \%$ \\ Race: $92 \%$ \\ Height (mean): $\mathrm{nr}$ \\ Weight (mean): $47 \mathrm{~kg}$ \\ BMI (mean): $\mathrm{nr}$ \\ LDL-C (mean): $6.5 \mathrm{mmol} / \mathrm{L}$
}

\begin{tabular}{ll}
\hline Interventions & * Treatment: pravastatin in 3 treatment arms $(n=53), 5$ mg daily ( $n=17 ?), 10$ mg daily ( $n=18 ?)$ and 20 \\
& mg daily $(n=18 ?)$ \\
& * Control: placebo $(n=18)$ \\
& * Run-in: diet + placebo for 8 weeks \\
& * Diet: lipid-lowering diet, pre-study diet evaluated with 5 day dietary recall
\end{tabular}

\begin{tabular}{l} 
Outcomes \\
TC: enzymatic method \\
HDL-C: enzymatic method \\
TG: enzymatic method \\
ASAT: routine biochemistry \\
ALAT: routine biochemistry \\
CK: routine biochemistry \\
Myopathy: myalgia, recorded by blinded physicians \\
Adverse events: adverse event, recorded by blinded physicians \\
\hline Notes \\
\hline
\end{tabular}

\title{
Risk of bias
}

\begin{tabular}{|c|c|c|}
\hline Bias & Authors' judgement & Support for judgement \\
\hline $\begin{array}{l}\text { Random sequence genera- } \\
\text { tion (selection bias) }\end{array}$ & Unclear risk & Described as stratified but randomization procedure not described. \\
\hline $\begin{array}{l}\text { Allocation concealment } \\
\text { (selection bias) }\end{array}$ & Unclear risk & $\mathrm{nr}$ \\
\hline $\begin{array}{l}\text { Blinding (performance } \\
\text { bias and detection bias) } \\
\text { All outcomes }\end{array}$ & Low risk & Double blind \\
\hline $\begin{array}{l}\text { Incomplete outcome data } \\
\text { (attrition bias) } \\
\text { All outcomes }\end{array}$ & Unclear risk & $\begin{array}{l}\text { Compliance: unclear } \\
\text { Dropout: } \mathrm{nr} \\
\text { Losses to follow-up: } 1 \% \\
\text { Missing from analysis: } 1 \%\end{array}$ \\
\hline $\begin{array}{l}\text { Selective reporting (re- } \\
\text { porting bias) }\end{array}$ & Unclear risk & No indication to suspect selective reporting. \\
\hline
\end{tabular}

McCrindle 2003

\begin{tabular}{ll}
\hline Methods & * \\
& Design: RCT \\
& * Randomization process: $\mathrm{nr}$ \\
& * Concealment of allocation: $\mathrm{nr}$ \\
& * Setting: 20 medical centers (6 USA, 5 Canada, 8 Europe, 1 South Africa) \\
& * Country: USA, Canada, Ireland, France, Spain, England, Sweden, Norway, South Africa \\
& * Follow-up: 26 weeks
\end{tabular}


McCrindle 2003 (Continued)

Participants
* Individuals with HeFH ( $=187$ )

* Diagnosis: FH or severe hypercholesterolemia and LDL-C $>4.9 \mathrm{mmol} / \mathrm{L}$ OR LDL-C $>4.1 \mathrm{mmol} / \mathrm{L}$ and family history of $\mathrm{FH} O R \mathrm{LDL}-\mathrm{C}>4.1 \mathrm{mmol} / \mathrm{L}$ and premature $\mathrm{CHD}$ in $1^{\circ} / 2^{\circ}$ relatives

* Inclusion: age 10 - 17 years; HeFH or LDL-C $\geqq 4.9 \mathrm{mmol} / \mathrm{L}$ or LDL-C $\geqq 4.1 \mathrm{mmol} / \mathrm{L}$ with $\mathrm{HC}$ or early AS in

family; Tanner $\geqq I I ; L D L-C \geqq 4.1 \mathrm{mmol} / \mathrm{L} \mathrm{w} /$ diet during baseline phase

* Exclusion: premenarche; pregnancy; under or overweight; liver or kidney disorder; HoFH; other clini-

cal trial; hypersensitivity to statins

* base population: $\mathrm{nr}$

Age: 10 - 17 years

Male: $69 \%$

Race: $92 \%$ white

Height (mean): $\mathrm{nr}$

Weight (mean): $\mathrm{nr}$

BMI (mean): $\mathrm{nr}$

LDL-C (mean): $5.7 \mathrm{mmol} / \mathrm{L}$

* Treatment: atorvastatin 10 - $20 \mathrm{mg}$ daily $(\mathrm{n}=140)$; median $20 \mathrm{mg}$, increased to $20 \mathrm{mg}$ if LDL-C $\geqq 3.4$ $\mathrm{mmol} / \mathrm{L}$ at 4 weeks

${ }^{*}$ Control: placebo $(n=47)$

* Run-in: washout for 4 weeks before the trial; placebo/diet run-in for 4 weeks

* Diet: NCEP step 1 diet; instructions in the beginning of the study

Outcomes
TC: : samples analyzed centrally
HDL-C: samples analyzed centrally
TG: samples analyzed centrally
ALAT: $>3 \times$ ULN samples analyzed in a routine manner
ASAT: $>3 \times$ ULN samples analyzed in a routine manner
Puberty: increase in Tanner staging $\geqq 1$, clinical examination
Adverse event: self-report or detected by the investigator

Notes

Risk of bias

\begin{tabular}{|c|c|c|}
\hline Bias & Authors' judgement & Support for judgement \\
\hline $\begin{array}{l}\text { Random sequence genera- } \\
\text { tion (selection bias) }\end{array}$ & Unclear risk & Described as randomized, process not reported. \\
\hline $\begin{array}{l}\text { Allocation concealment } \\
\text { (selection bias) }\end{array}$ & Unclear risk & $\mathrm{nr}$ \\
\hline $\begin{array}{l}\text { Blinding (performance } \\
\text { bias and detection bias) } \\
\text { All outcomes }\end{array}$ & Low risk & Double blind \\
\hline $\begin{array}{l}\text { Incomplete outcome data } \\
\text { (attrition bias) } \\
\text { All outcomes }\end{array}$ & Low risk & $\begin{array}{l}\text { Compliance: } \mathrm{nr} \\
\text { Dropout: } 2 \% \\
\text { Losses to follow-up: } 0 \% \\
\text { Missing from analysis: } 0 \%\end{array}$ \\
\hline $\begin{array}{l}\text { Selective reporting (re- } \\
\text { porting bias) }\end{array}$ & Unclear risk & No indication to suspect selective reporting. \\
\hline
\end{tabular}


Stein 1999

\begin{tabular}{|c|c|}
\hline Methods & $\begin{array}{l}\text { * Design: RCT } \\
\text { * Randomization process: nr } \\
\text { * Blinding: double } \\
\text { * Concealment of allocation: nr } \\
\text { * Setting: } 14 \text { pediatric clinics (13 USA, } 1 \text { Finland) } \\
\text { * Country: USA, Finland } \\
\text { * Follow-up: } 24 \text { and } 48 \text { weeks }\end{array}$ \\
\hline Participants & $\begin{array}{l}\text { * Participants with } \mathrm{HeFH}(\mathrm{N}=132) \\
{ }^{*} \text { Diagnosis: } \mathrm{LDL}-\mathrm{C}>4.9 \mathrm{mmol} / \mathrm{L} \text { and } 1 \text { parent } \mathrm{LDL}-\mathrm{C}>4.9 \mathrm{mmol} / \mathrm{l} \text {; or } \mathrm{LDL}-\mathrm{C}>5.7 \mathrm{mmol} / \mathrm{L} \text { and CAD death } \\
\text { in } 1 \text { parent } \\
\text { * Inclusion: age } 10-17 \text { years; } \mathrm{LDL}-\mathrm{C} 4.9-13.0 \mathrm{mmol} / \mathrm{L} \text { on diet } \text { and } \geqq 1 \text { parent with } \mathrm{LDL}-\mathrm{C} \geqq 4.9 \mathrm{mmol} / \mathrm{L} \\
\text { with or LDL-C } 5.7-13.0 \mathrm{mmol} / \mathrm{L} \text { on diet and a parent died of CAD; (Tanner }>\text { I required later by FDA }>8 \\
\text { participants needed to discontinue) } \\
{ }^{\star} \text { Exclusion: delayed puberty; under/overweight; HoFH; secondary hyperlipidaemia; TG disorders } \\
\text { * Base population: unclear } \\
{ }^{*} \text { Age: } 11-17 \text { years } \\
{ }^{*} \text { Male: } 100 \% \\
{ }^{*} \text { Race: } 93 \% \\
{ }^{*} \text { Height (mean): } 159 \mathrm{~cm} \\
{ }^{*} \text { Weight (mean): } 52 \mathrm{~kg} \\
\text { * BMI (mean): } 21 \mathrm{~kg} / \mathrm{m}^{2} \\
{ }^{*} \text { LDLC (mean): } 6.5 \mathrm{mmol} / \mathrm{L}\end{array}$ \\
\hline
\end{tabular}

Interventions

* Treatment: lovastatin $40 \mathrm{mg}$ in the evening $(n=63)$; started with $10 \mathrm{mg}$, increased to $20 / 40 \mathrm{mg}$ at weeks $8 / 16$

${ }^{\star}$ Control: placebo $(n=59)$

* Run-in: diet for 4 months; placebo run-in for 4 weeks

* Diet: AHA pediatric diet; instructed, monitored and evaluated throughout trial

\begin{tabular}{l}
\hline Lutcomes \\
TC: enzymatic method \\
HDL-C: heparin-manganese chloride method \\
TG: enzymatic method \\
ALAT > $3 \times$ ULN: samples analyzed centrally \\
ASAT > $3 \times$ ULN: samples analyzed centrally \\
CK $>10 \times$ ULN: samples analyzed centrally \\
Myalgia criteria: nr \\
Adverse event: new or worsening clinical adverse event, not otherwise specified
\end{tabular}

Notes

\section{Risk of bias}

\begin{tabular}{lll}
\hline Bias & Authors' judgement & Support for judgement \\
\hline $\begin{array}{l}\text { Random sequence genera- } \\
\text { tion (selection bias) }\end{array}$ & Unclear risk & Described as randomized, process not reported. \\
\hline $\begin{array}{l}\text { Allocation concealment } \\
\text { (selection bias) }\end{array}$ & Unclear risk & $\mathrm{nr}$ \\
\hline $\begin{array}{l}\text { Blinding (performance } \\
\text { bias and detection bias) } \\
\text { All outcomes }\end{array}$ & Low risk & Double blind \\
\hline $\begin{array}{l}\text { Incomplete outcome data } \\
\text { (attrition bias) }\end{array}$ & Low risk & \\
\hline
\end{tabular}


Stein 1999 (Continued)

All outcomes

Losses to follow-up: $8 \%$

Missing from analysis: $8 \%$

Selective reporting (re- Unclear risk $\quad$ No indication to suspect selective reporting.
porting bias)

Wiegman 2004

$\begin{array}{ll}\text { Methods } & \text { * Design: RCT } \\ & \text { * Randomization computer-generated in blocks of } 8 \\ & \text { * Blinding: double } \\ & \text { * Compliance monitored by tablet counting } \\ & \text { * Concealment of allocation: } \mathrm{nr} \\ & \text { * Setting: } 1 \text { medical center } \\ & \text { * Country: Netherlands } \\ & \text { * Follow-up: } 104 \text { weeks }\end{array}$

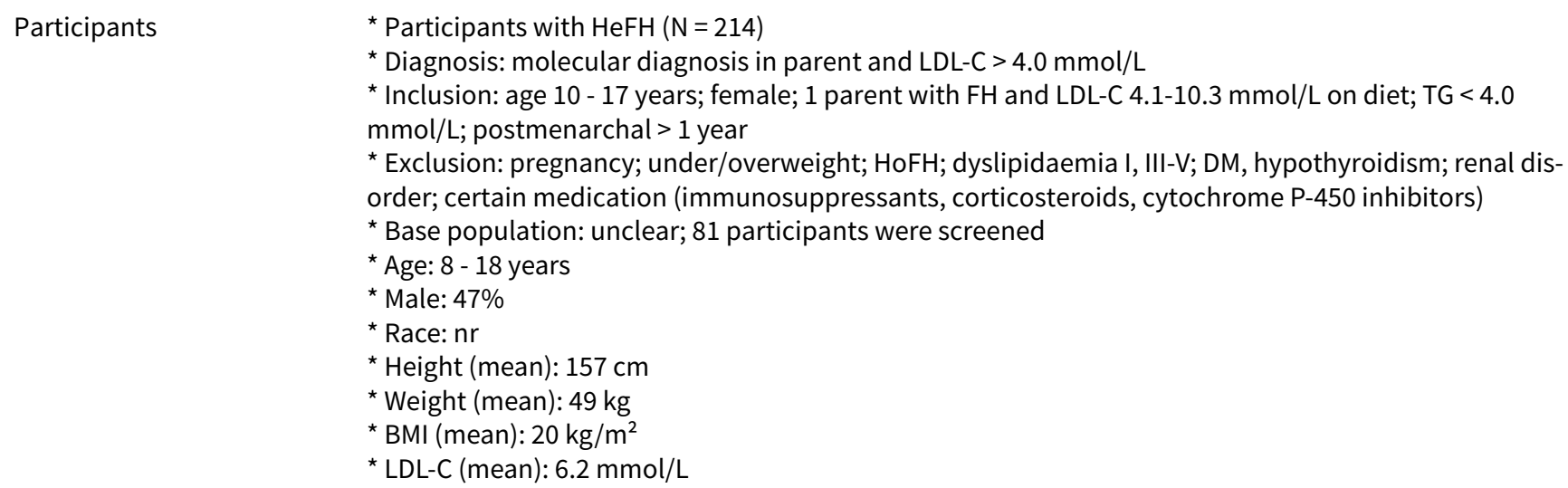

Outcomes LDL-C: enzymatic method, calculated Friedewald's formula

TC: enzymatic method

HDL-C: naheparin-manganese chloride method

TG: enzymatic method

ALAT: > $3 \times$ ULN, analysis method: $\mathrm{nr}$

ASAT: $>3 \times$ ULN, analysis method: $\mathrm{nr}$

CPK: $>4 \times$ ULN, analysis method: $\mathrm{nr}$

IMT: ultrasonography; method described

Puberty: Tanner staging, clinical examination

Notes

\section{Risk of bias}

\begin{tabular}{lll}
\hline Bias & Authors' judgement & Support for judgement \\
\hline $\begin{array}{l}\text { Random sequence genera- } \\
\text { tion (selection bias) }\end{array}$ & Low risk & Computer-generated in blocks of 8. \\
\hline
\end{tabular}


Wiegman 2004 (Continued)

\begin{tabular}{|c|c|c|}
\hline $\begin{array}{l}\text { Allocation concealment } \\
\text { (selection bias) }\end{array}$ & Unclear risk & $\mathrm{nr}$ \\
\hline $\begin{array}{l}\text { Blinding (performance } \\
\text { bias and detection bias) } \\
\text { All outcomes }\end{array}$ & Low risk & Double blind \\
\hline $\begin{array}{l}\text { Incomplete outcome data } \\
\text { (attrition bias) } \\
\text { All outcomes }\end{array}$ & Low risk & $\begin{array}{l}\text { Compliance: unclear } \\
\text { Dropout: } 5 \% \\
\text { Losses to follow-up: } 1 \% \\
\text { Missing from analysis: } 1 \%\end{array}$ \\
\hline $\begin{array}{l}\text { Selective reporting (re- } \\
\text { porting bias) }\end{array}$ & Unclear risk & No indication to suspect selective reporting. \\
\hline
\end{tabular}

AHA: American Heart Association

ALAT: alanine amino transferase

ASAT: aspartate amino transferase

BMI: body mass index

CAD: coronary artery disease

CK: creatine kinase

CRP: C-reactive protein

CVD: cardiovascular disease

DM: diabetes mellitus

$\mathrm{FH}$ : familial hypercholesterolemia

FMD: flow-mediated dilatation

HC: hypercholesterolemia

HDL-C: high-density lipoprotein cholesterol

$\mathrm{HeFH}$ : heterozygous familial hypercholesterolemia

$\mathrm{HoFH}$ : homozygous familial hypercholesterolemia

HT: hypertension

IMT: intima-media thickness

LDL-C: low-density lipoprotein cholesterol

NCEP: National Cholesterol Education Panel

nr: not reported

$\mathrm{RCT}$ : randomized controlled trial

TC: total cholesterol

TG: triglycerides

ULN: upper limit of normal

Characteristics of excluded studies [ordered by study ID]

\begin{tabular}{ll}
\hline Study & Reason for exclusion \\
\hline Athyros 2002 & Publication type letter, no control group, not enough information reported. \\
\hline Braaskamp 2015b & Cohort study. \\
\hline Braaskamp 2015c & Clinical trial without randomization. \\
\hline Carreau 2011 & Cohort study. \\
\hline Chan 2016 & No control group without medication. \\
\hline Dirisamer 2003 & Clinical trial, no control group. \\
\hline
\end{tabular}




\begin{tabular}{|c|c|}
\hline Study & Reason for exclusion \\
\hline Gandelman 2011 & Clinical trial, no control group, open-label. \\
\hline Harada-Shiba 2018 & $\begin{array}{l}\text { The results of } 2 \text { studies reported: the study in Japan is an original RCT but without a placebo con- } \\
\text { trol group, the European study has been reported earlier (see Braaskamp 2015). }\end{array}$ \\
\hline Hedman 2003 & Clinical trial, no control group. \\
\hline Hedman 2005 & Clinical trial, no control group. \\
\hline Lambert 1996 & Clinical trial, no control group. \\
\hline Langslet 2016 & Clinical trial, no placebo control group \\
\hline McCrindle 2002 & $\begin{array}{l}\text { Randomized cross-over trial, comparison unacceptable (i.e. combination of } 2 \text { active drugs): one in- } \\
\text { tervention was } 10 \mathrm{mg} \text { pravastatin plus } 5 \mathrm{~g} \text { colestipol and the other } 10 \mathrm{~g} \text { colestipol. }\end{array}$ \\
\hline Raal 1997 & Clinical trial, no control group. \\
\hline Sinzinger 2004 & Cohort study. \\
\hline Stefanutti 1999 & $\begin{array}{l}\text { Clinical trial, control diet alone, controls were not clearly defined, e.g. the diagnostic criteria for } \\
\text { heterozygous FH not reported, only age of the participants given. }\end{array}$ \\
\hline Stein 1989 & Cohort study. \\
\hline Stein 2016 & Participants had homozygous FH. \\
\hline Tada 2016 & No control group without medication. \\
\hline Teramoto 2016 & PCSK 9 inhibitor used as add-on therapy and also not only people with FH included. \\
\hline van der Graaf 2006 & Clinical trial, no control group. \\
\hline
\end{tabular}

FH: familial hypercholesterolemia

\section{DATA AND ANALYSES}

\section{Comparison 1. Statins versus control}

\begin{tabular}{lllll}
\hline Outcome or subgroup title & $\begin{array}{l}\text { No. of } \\
\text { studies }\end{array}$ & $\begin{array}{l}\text { No. of } \\
\text { partici- } \\
\text { pants }\end{array}$ & Statistical method & Effect size \\
\hline $\begin{array}{l}1 \text { Change in carotid intima-media } \\
\text { thickness (mm) }\end{array}$ & 1 & Mean Difference (IV, Fixed, 95\% Cl) & Totals not selected \\
\hline $\begin{array}{l}1.1 \text { At 2 years } \\
2 \text { Change in serum LDL cholesterol }\end{array}$ & 6 & Mean Difference (IV, Fixed, $95 \% \mathrm{Cl})$ & $0.0[0.0,0.0]$ \\
\hline level (\%) & 1 & Mean Difference (IV, Fixed, $95 \% \mathrm{Cl})$ & Subtotals only \\
\hline 2.1 At 1 month & 3 & 228 & Mean Difference (IV, Fixed, $95 \% \mathrm{Cl})$ & $-24.59[-30.11,-19.08]$ \\
\hline
\end{tabular}




\begin{tabular}{|c|c|c|c|c|}
\hline Outcome or subgroup title & $\begin{array}{l}\text { No. of } \\
\text { studies }\end{array}$ & $\begin{array}{l}\text { No. of } \\
\text { partici- } \\
\text { pants }\end{array}$ & Statistical method & Effect size \\
\hline 2.2 At 6 months & 4 & 528 & Mean Difference (IV, Fixed, 95\% CI) & $-34.97[-37.51,-32.44]$ \\
\hline 2.3 At 1 year & 2 & 254 & Mean Difference (IV, Fixed, 95\% CI) & $-26.94[-31.64,-22.23]$ \\
\hline 2.4 At end of follow-up & 6 & 669 & Mean Difference (IV, Fixed, 95\% CI) & $-32.15[-34.90,-29.40]$ \\
\hline $\begin{array}{l}3 \text { Change in puberty (Tanner stage } \\
\geqq 1 \text { level) }\end{array}$ & 3 & & Risk Ratio (M-H, Fixed, 95\% Cl) & Subtotals only \\
\hline 3.1 At 6 months & 2 & 355 & Risk Ratio (M-H, Fixed, 95\% Cl) & $0.99[0.66,1.50]$ \\
\hline 3.2 At 1 year & 1 & 139 & Risk Ratio (M-H, Fixed, 95\% Cl) & $0.89[0.51,1.54]$ \\
\hline 3.3 At 2 years & 1 & 211 & Risk Ratio (M-H, Fixed, 95\% Cl) & $0.95[0.77,1.18]$ \\
\hline $\begin{array}{l}4 \text { Change in aspartate aminotrans- } \\
\text { ferase levels }(>3 x \text { ULN) }\end{array}$ & 7 & & Risk Ratio (M-H, Fixed, 95\% CI) & Subtotals only \\
\hline 4.1 At 1 month & 2 & 175 & Risk Ratio (M-H, Fixed, 95\% CI) & $0.0[0.0,0.0]$ \\
\hline 4.2 At 6 months & 4 & 538 & Risk Ratio (M-H, Fixed, 95\% Cl) & $2.40[0.29,19.85]$ \\
\hline 4.3 At 1 year & 2 & 254 & Risk Ratio (M-H, Fixed, 95\% Cl) & $2.03[0.08,49.09]$ \\
\hline 4.4 At 2 years & 1 & 211 & Risk Ratio (M-H, Fixed, 95\% CI) & $0.21[0.01,4.23]$ \\
\hline $\begin{array}{l}5 \text { Change in alanine aminotrans- } \\
\text { ferase levels ( }>3 x \text { ULN) }\end{array}$ & 7 & & Risk Ratio (M-H, Fixed, 95\% CI) & Subtotals only \\
\hline 5.1 At 1 month & 2 & 175 & Risk Ratio (M-H, Fixed, 95\% Cl) & $0.0[0.0,0.0]$ \\
\hline 5.2 At 6 months & 4 & 538 & Risk Ratio (M-H, Fixed, 95\% Cl) & $2.03[0.24,16.95]$ \\
\hline 5.3 At 1 year & 2 & 254 & Risk Ratio (M-H, Fixed, 95\% Cl) & $2.03[0.08,49.09]$ \\
\hline 5.4 At 2 years & 1 & 211 & Risk Ratio (M-H, Fixed, 95\% Cl) & $0.0[0.0,0.0]$ \\
\hline $\begin{array}{l}6 \text { Myopathy: Change in creatine ki- } \\
\text { nase levels (>10x ULN) }\end{array}$ & 6 & & Risk Ratio (M-H, Fixed, 95\% CI) & Subtotals only \\
\hline 6.1 At 1 month & 3 & 330 & Risk Ratio (M-H, Fixed, 95\% Cl) & $3.23[0.18,58.84]$ \\
\hline 6.2 At 6 months & 2 & 229 & Risk Ratio (M-H, Fixed, 95\% Cl) & $0.22[0.01,5.28]$ \\
\hline 6.3 At 1 year & 2 & 254 & Risk Ratio (M-H, Fixed, 95\% Cl) & $0.67[0.04,10.57]$ \\
\hline $\begin{array}{l}7 \text { Change in flow-mediated dilata- } \\
\text { tion of brachial artery (\%) }\end{array}$ & 1 & & Mean Difference (IV, Fixed, 95\% CI) & Totals not selected \\
\hline 7.1 At 6 months & 1 & & Mean Difference (IV, Fixed, 95\% CI) & $0.0[0.0,0.0]$ \\
\hline $\begin{array}{l}8 \text { Change in serum total choles- } \\
\text { terol levels }(\%)\end{array}$ & 6 & & Mean Difference (IV, Fixed, 95\% CI) & Subtotals only \\
\hline
\end{tabular}




\begin{tabular}{|c|c|c|c|c|}
\hline Outcome or subgroup title & $\begin{array}{l}\text { No. of } \\
\text { studies }\end{array}$ & $\begin{array}{l}\text { No. of } \\
\text { partici- } \\
\text { pants }\end{array}$ & Statistical method & Effect size \\
\hline 8.1 At 1 month & 3 & 228 & Mean Difference (IV, Fixed, 95\% CI) & $-18.31[-22.55,-14.06]$ \\
\hline 8.2 At 6 months & 4 & 528 & Mean Difference (IV, Fixed, 95\% CI) & $-24.28[-26.09,-22.47]$ \\
\hline 8.3 At 1 year & 2 & 254 & Mean Difference (IV, Fixed, 95\% CI) & $-27.60[-30.64,-24.57]$ \\
\hline 8.4 At the end of follow-up & 6 & 669 & Mean Difference (IV, Fixed, 95\% CI) & $-26.53[-28.54,-24.51]$ \\
\hline $\begin{array}{l}9 \text { Change in serum HDL cholesterol } \\
\text { levels }(\%)\end{array}$ & 6 & & Mean Difference (IV, Fixed, 95\% CI) & Subtotals only \\
\hline 9.1 At 1 month & 3 & 228 & Mean Difference (IV, Fixed, 95\% CI) & $3.0[-2.47,8.47]$ \\
\hline 9.2 At 6 months & 4 & 528 & Mean Difference (IV, Fixed, 95\% CI) & $4.18[1.54,6.82]$ \\
\hline 9.3 At 1 year & 2 & 254 & Mean Difference (IV, Fixed, 95\% CI) & $2.56[-1.17,6.29]$ \\
\hline 9.4 At the end of follow-up & 6 & 669 & Mean Difference (IV, Fixed, 95\% CI) & $3.11[0.55,5.67]$ \\
\hline $\begin{array}{l}10 \text { Change in serum triglyceride } \\
\text { levels }(\%)\end{array}$ & 5 & & Mean Difference (IV, Fixed, 95\% CI) & Subtotals only \\
\hline 10.1 At 1 month & 3 & 228 & Mean Difference (IV, Fixed, 95\% CI) & $10.31[-5.11,25.74]$ \\
\hline 10.2 At 6 months & 3 & 363 & Mean Difference (IV, Fixed, 95\% CI) & $-9.34[-18.90,0.22]$ \\
\hline 10.3 At 1 year & 1 & 110 & Mean Difference (IV, Fixed, 95\% CI) & $0.0[-18.09,18.09]$ \\
\hline 10.4 At the end of follow-up & 5 & 525 & Mean Difference (IV, Fixed, 95\% CI) & $-3.27[-12.03,5.50]$ \\
\hline 11 Adverse events & 6 & & Risk Ratio (M-H, Fixed, 95\% Cl) & Subtotals only \\
\hline 11.1 At 1 month & 2 & 248 & Risk Ratio (M-H, Fixed, 95\% Cl) & $0.86[0.65,1.13]$ \\
\hline 11.2 At 6 months & 3 & 416 & Risk Ratio (M-H, Fixed, 95\% Cl) & $1.02[0.82,1.27]$ \\
\hline 11.3 At 1 year & 2 & 276 & Risk Ratio (M-H, Fixed, 95\% Cl) & $1.01[0.81,1.26]$ \\
\hline
\end{tabular}

\section{Analysis 1.1. Comparison 1 Statins versus control, Outcome 1 Change in carotid intima-media thickness (mm).}

\begin{tabular}{|c|c|c|c|c|c|c|c|}
\hline \multirow[t]{2}{*}{ Study or subgroup } & \multicolumn{2}{|c|}{ Statins } & \multicolumn{2}{|c|}{ Placebo } & \multirow{2}{*}{\multicolumn{2}{|c|}{$\begin{array}{c}\text { Mean Difference } \\
\text { Fixed, } 95 \% \mathrm{Cl}\end{array}$}} & \multirow{2}{*}{$\begin{array}{c}\text { Mean Difference } \\
\text { Fixed, } 95 \% \mathrm{Cl} \\
\end{array}$} \\
\hline & $\mathbf{N}$ & $\operatorname{Mean}(\mathrm{SD})$ & $\mathbf{N}$ & Mean(SD) & & & \\
\hline \multicolumn{8}{|l|}{ 1.1.1 At 2 years } \\
\hline Wiegman 2004 & 104 & $-0(0)$ & 107 & $0(0)$ & 一 & & $-0.01[-0.03,-0]$ \\
\hline
\end{tabular}


Analysis 1.2. Comparison 1 Statins versus control, Outcome 2 Change in serum LDL cholesterol level (\%).

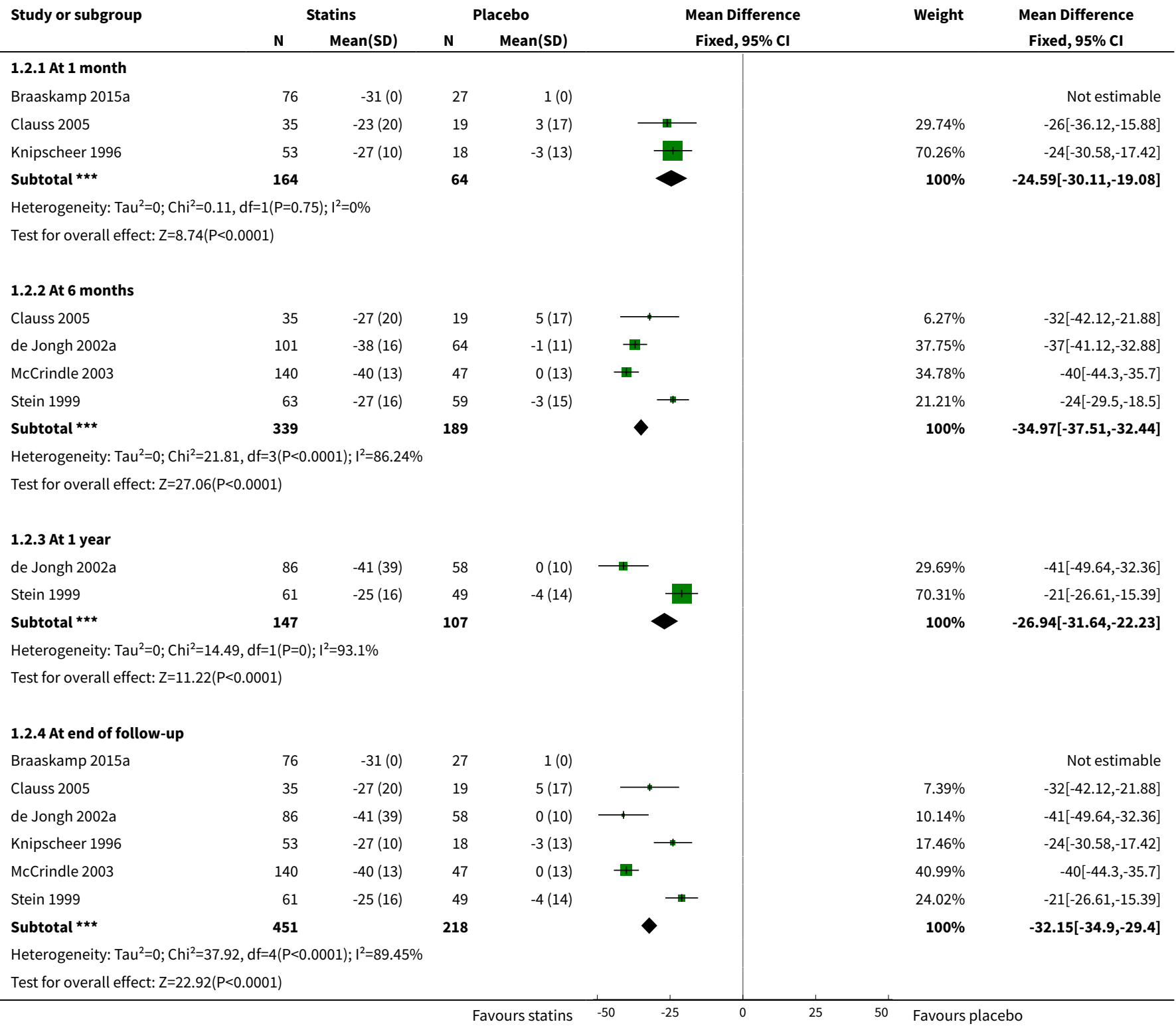

Analysis 1.3. Comparison 1 Statins versus control, Outcome 3 Change in puberty (Tanner stage $\geqq 1$ level).

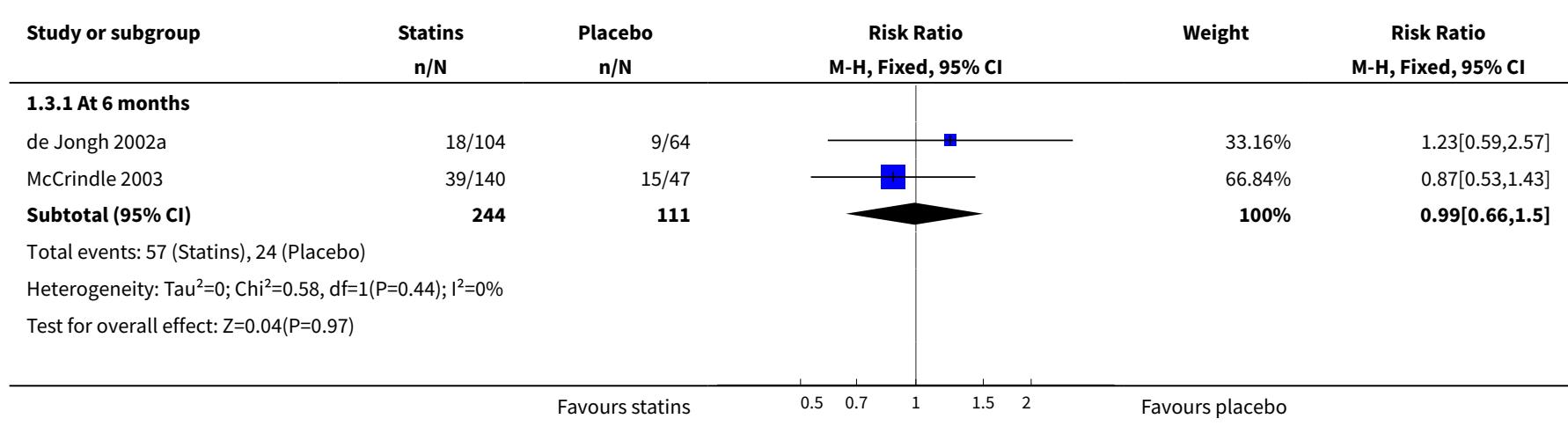




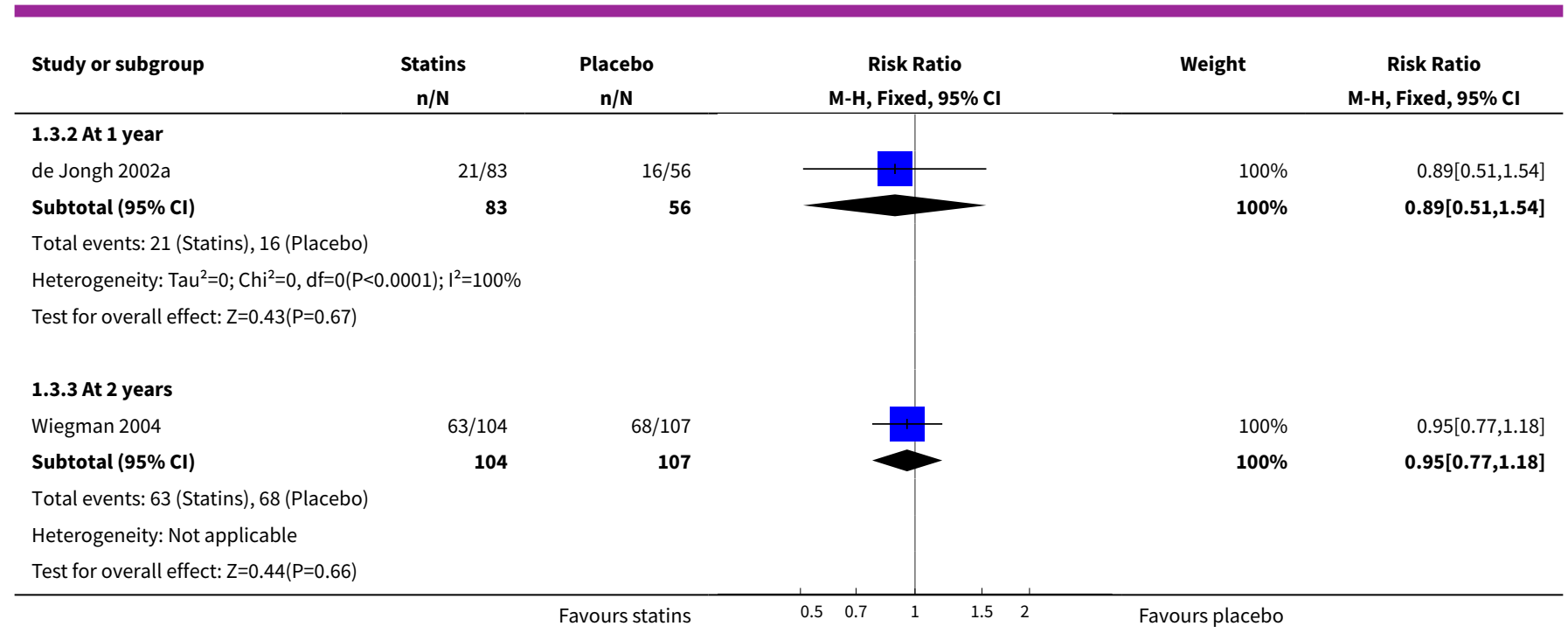

\section{Analysis 1.4. Comparison 1 Statins versus control, Outcome 4 Change in aspartate aminotransferase levels (> $3 \times$ ULN).}

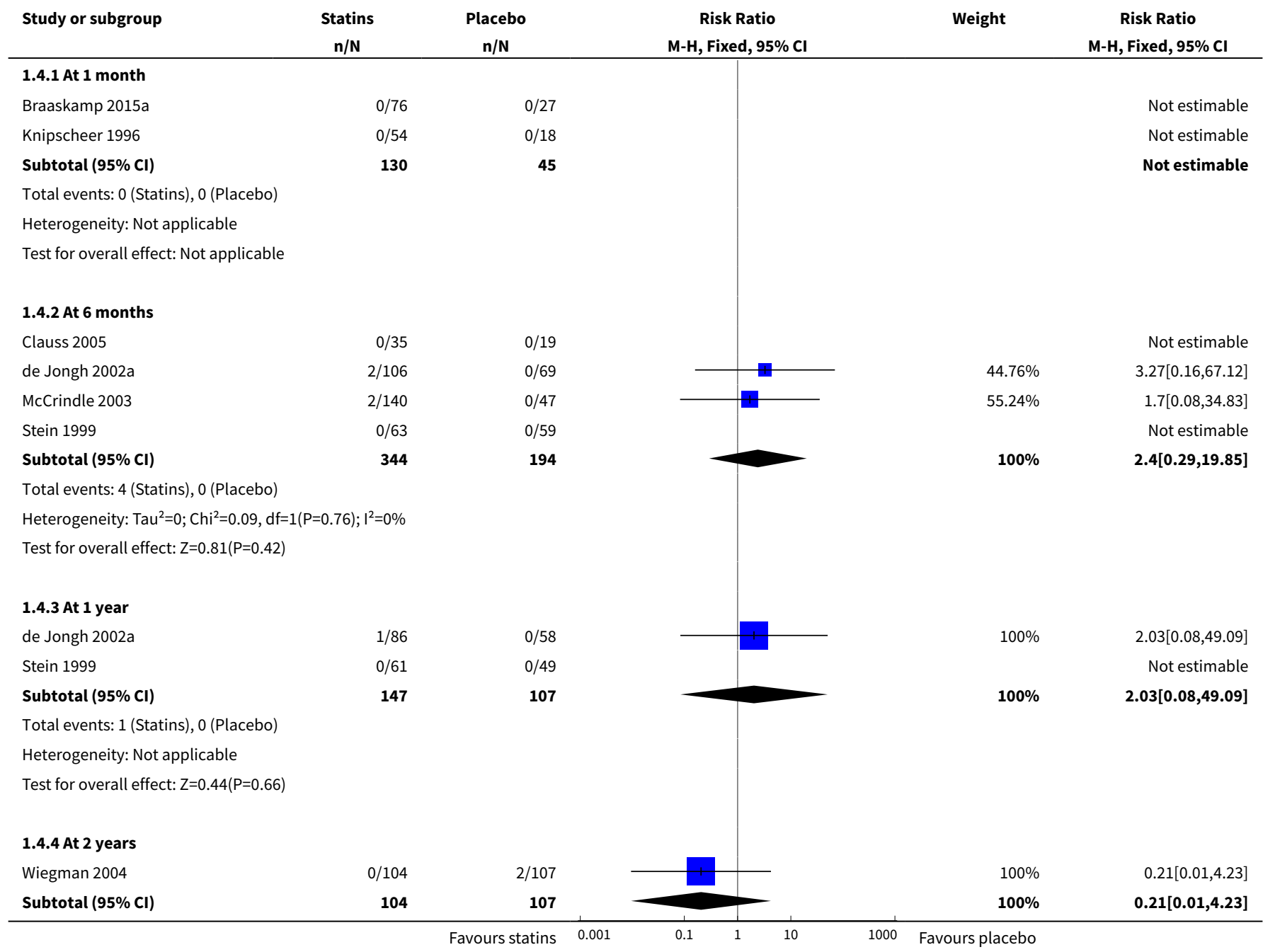




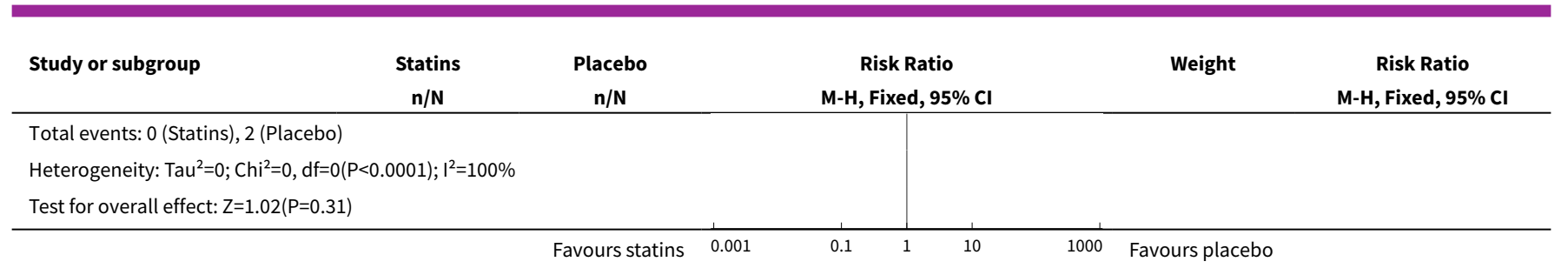

Analysis 1.5. Comparison 1 Statins versus control, Outcome 5 Change in alanine aminotransferase levels (> $3 \times$ ULN).

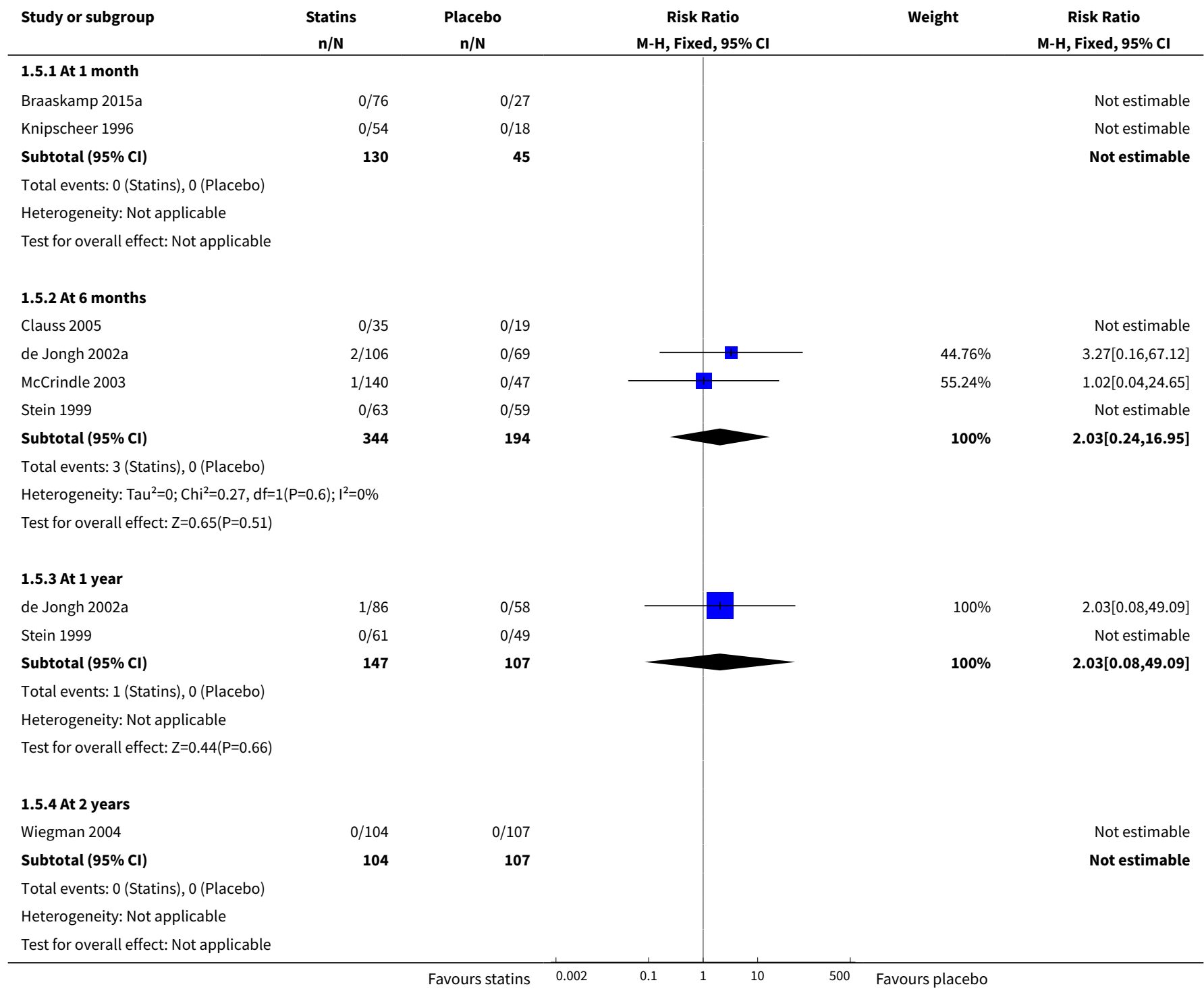


Analysis 1.6. Comparison 1 Statins versus control, Outcome 6 Myopathy: Change in creatine kinase levels (> 10x ULN).

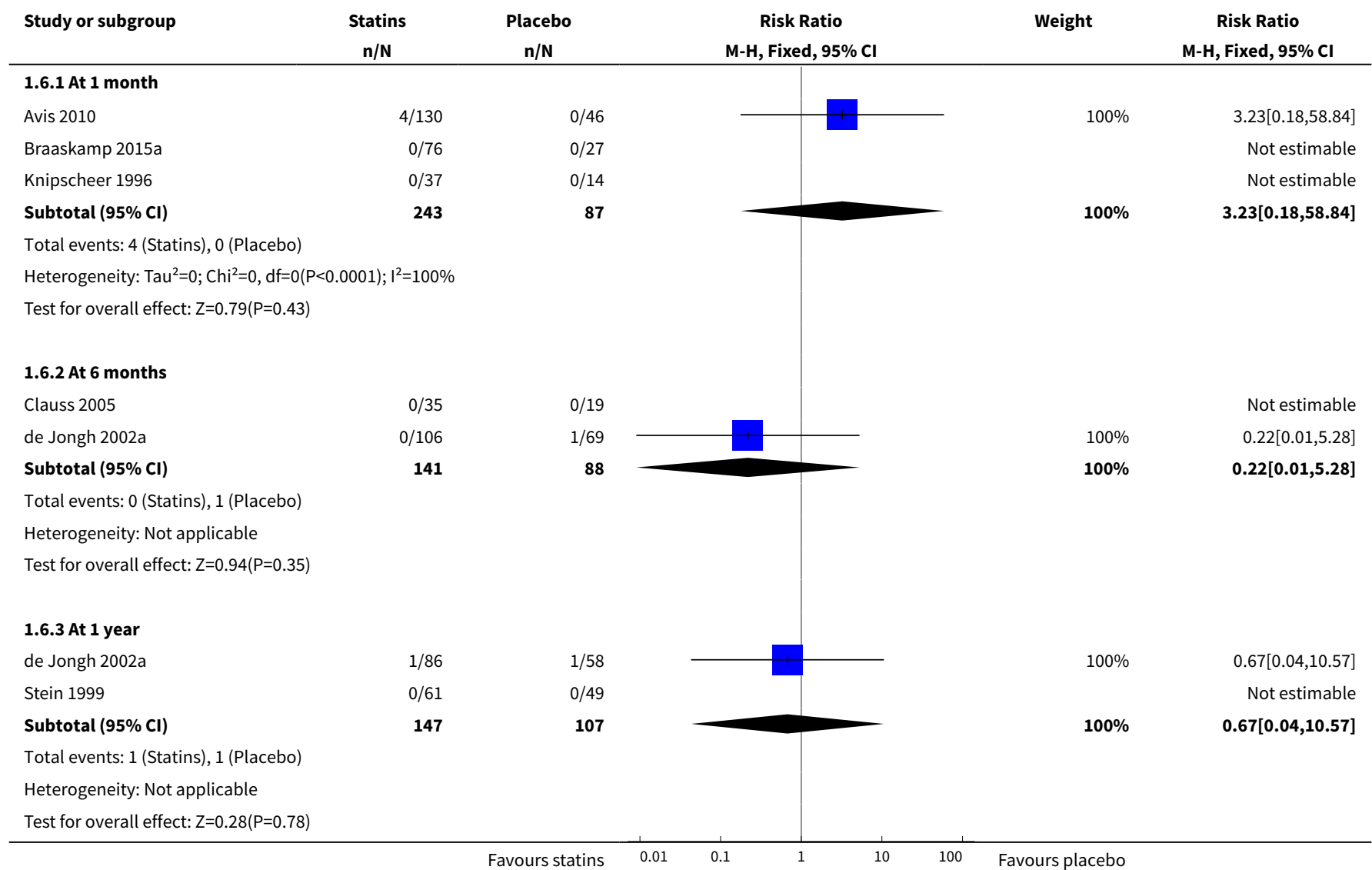

Analysis 1.7. Comparison 1 Statins versus control, Outcome 7 Change in flow-mediated dilatation of brachial artery (\%).

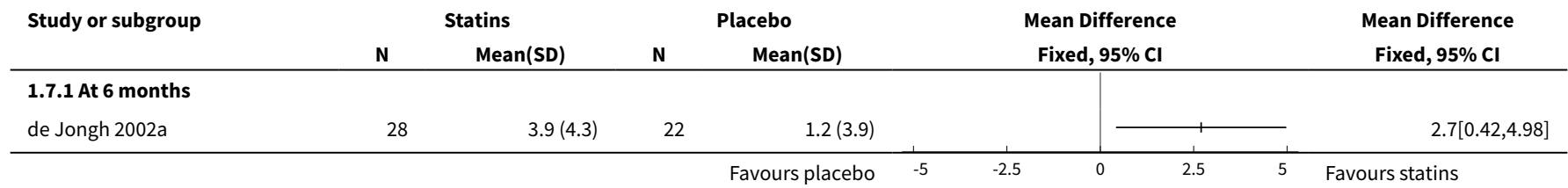

Analysis 1.8. Comparison 1 Statins versus control, Outcome 8 Change in serum total cholesterol levels (\%).

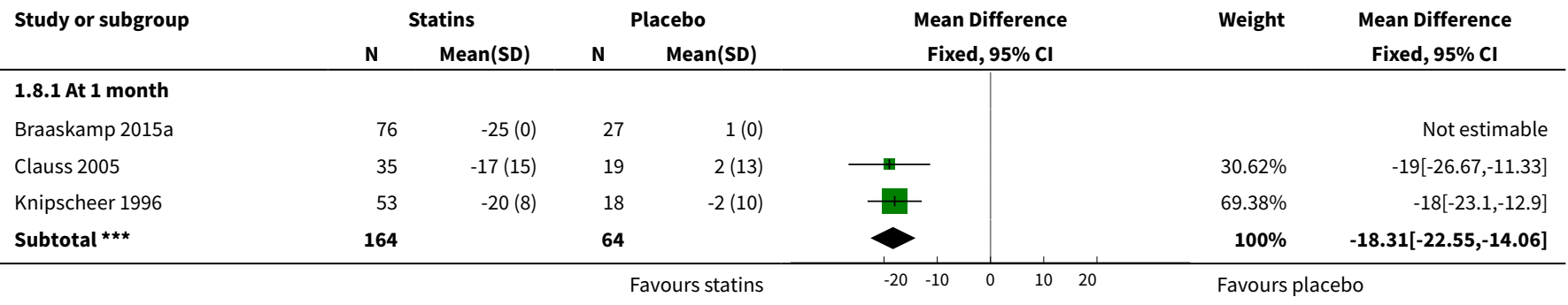




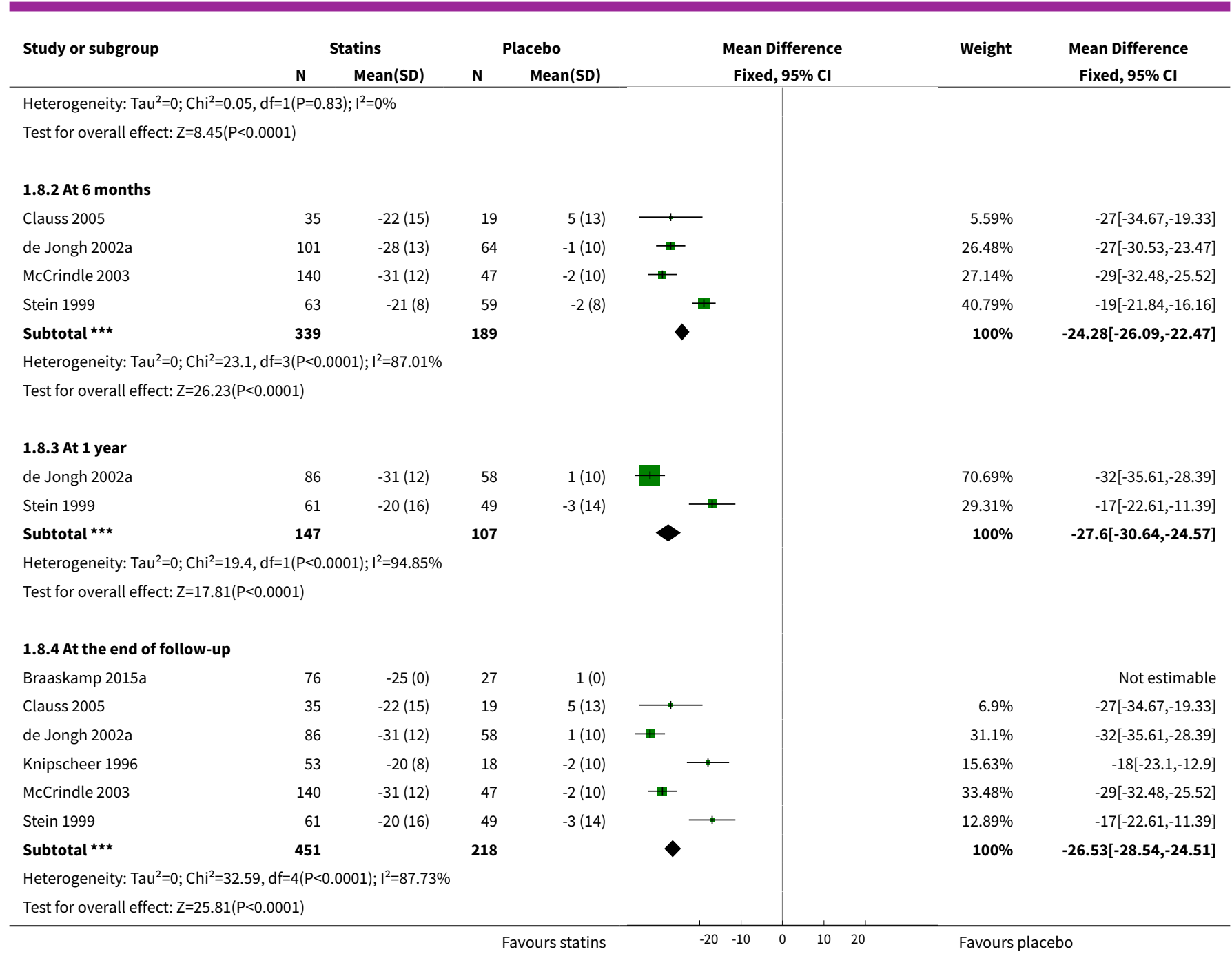

Analysis 1.9. Comparison 1 Statins versus control, Outcome 9 Change in serum HDL cholesterol levels (\%).

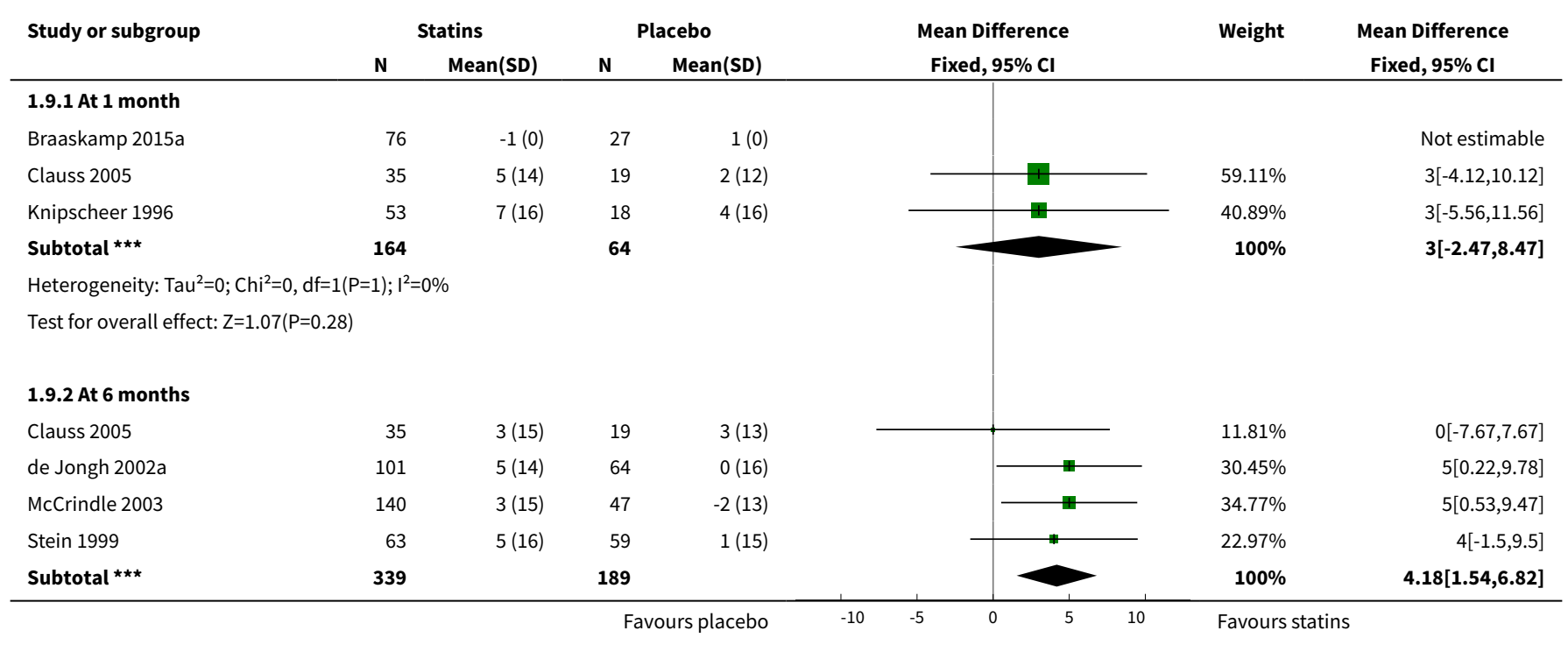




\begin{tabular}{|c|c|c|c|c|c|c|c|}
\hline \multirow[t]{2}{*}{ Study or subgroup } & \multicolumn{2}{|c|}{ Statins } & \multicolumn{2}{|c|}{ Placebo } & \multirow{2}{*}{$\begin{array}{c}\text { Mean Difference } \\
\text { Fixed, } 95 \% \mathrm{Cl}\end{array}$} & \multirow[t]{2}{*}{ Weight } & \multirow{2}{*}{$\begin{array}{c}\text { Mean Difference } \\
\text { Fixed, } 95 \% \mathrm{Cl}\end{array}$} \\
\hline & $\mathbf{N}$ & Mean(SD) & $\mathbf{N}$ & Mean(SD) & & & \\
\hline \multicolumn{8}{|c|}{ Heterogeneity: $\mathrm{Tau}^{2}=0 ; \mathrm{Chi}^{2}=1.39, \mathrm{df}=3(\mathrm{P}=0.71) ; \mathrm{I}^{2}=0 \%$} \\
\hline \multicolumn{8}{|c|}{ Test for overall effect: $Z=3.11(P=0)$} \\
\hline \multicolumn{8}{|l|}{ 1.9.3 At 1 year } \\
\hline Stein 1999 & 61 & $1(16)$ & 49 & $-1(14)$ & & $44.21 \%$ & $2[-3.61,7.61]$ \\
\hline Subtotal $* \star \star$ & 147 & & 107 & & & $100 \%$ & $2.56[-1.17,6.29]$ \\
\hline \multicolumn{8}{|c|}{ Heterogeneity: $\mathrm{Tau}^{2}=0 ; \mathrm{Chi}^{2}=0.07, \mathrm{df}=1(\mathrm{P}=0.79) ; \mathrm{I}^{2}=0 \%$} \\
\hline \multicolumn{8}{|c|}{ Test for overall effect: $Z=1.34(P=0.18)$} \\
\hline \multicolumn{8}{|c|}{ 1.9.4 At the end of follow-up } \\
\hline Clauss 2005 & 35 & $3(15)$ & 19 & $3(13)$ & & $11.14 \%$ & $0[-7.67,7.67]$ \\
\hline de Jongh 2002a & 86 & $3(15)$ & 58 & $0(15)$ & & $26.28 \%$ & $3[-2,8]$ \\
\hline Knipscheer 1996 & 53 & $7(16)$ & 18 & $4(16)$ & & $8.96 \%$ & $3[-5.56,11.56]$ \\
\hline McCrindle 2003 & 140 & $3(15)$ & 47 & $-2(13)$ & + & $32.8 \%$ & $5[0.53,9.47]$ \\
\hline Stein 1999 & 61 & $1(16)$ & 49 & $-1(14)$ & & $20.82 \%$ & $2[-3.61,7.61]$ \\
\hline 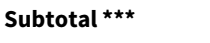 & 451 & & 218 & & & $100 \%$ & $3.11[0.55,5.67]$ \\
\hline \multicolumn{8}{|c|}{ Heterogeneity: $\operatorname{Tau}^{2}=0 ; \mathrm{Chi}^{2}=1.47, \mathrm{df}=4(\mathrm{P}=0.83) ; \mathrm{I}^{2}=0 \%$} \\
\hline Test for overall effec & & & & & & & \\
\hline
\end{tabular}

Analysis 1.10. Comparison 1 Statins versus control, Outcome 10 Change in serum triglyceride levels (\%).

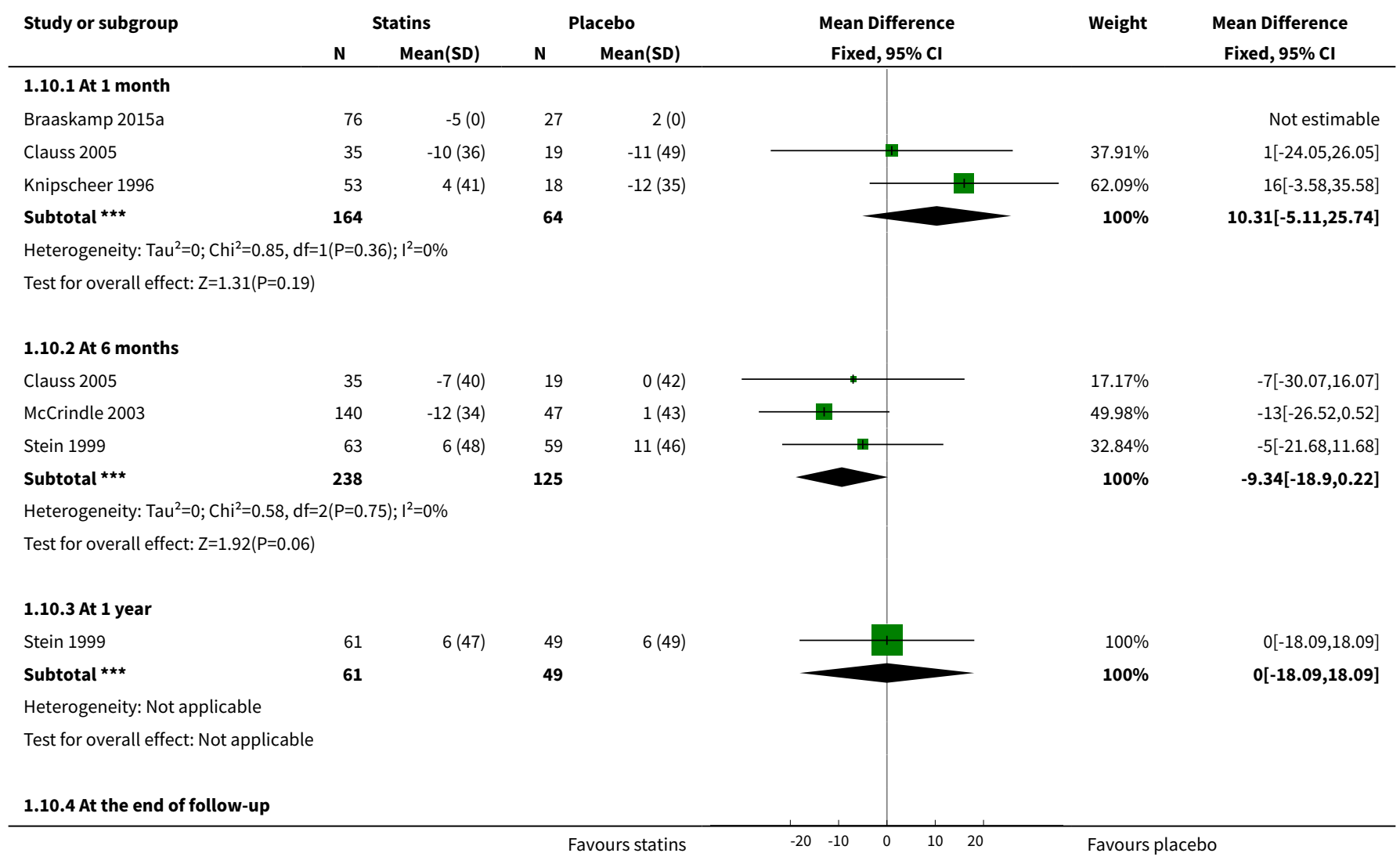




\begin{tabular}{|c|c|c|c|c|c|c|c|}
\hline \multirow{3}{*}{$\begin{array}{l}\text { Study or subgroup } \\
\text { Braaskamp 2015a }\end{array}$} & \multicolumn{2}{|c|}{ Statins } & \multicolumn{2}{|c|}{ Placebo } & \multirow{2}{*}{$\begin{array}{c}\text { Mean Difference } \\
\text { Fixed, } 95 \% \mathrm{Cl} \\
\end{array}$} & \multirow[t]{2}{*}{ Weight } & \multirow{2}{*}{$\begin{array}{c}\text { Mean Difference } \\
\text { Fixed, } 95 \% \mathrm{Cl} \\
\end{array}$} \\
\hline & $\mathbf{N}$ & $\operatorname{Mean}(S D)$ & $\mathbf{N}$ & Mean(SD) & & & \\
\hline & 76 & $-5(0)$ & 27 & $2(0)$ & & & Not estimable \\
\hline Clauss 2005 & 35 & $-7(40)$ & 19 & $0(42)$ & & $14.44 \%$ & $-7[-30.07,16.07]$ \\
\hline Knipscheer 1996 & 53 & $4(41)$ & 18 & $-12(35)$ & & $20.05 \%$ & $16[-3.58,35.58]$ \\
\hline McCrindle 2003 & 140 & $-12(34)$ & 47 & $1(43)$ & 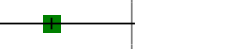 & $42.03 \%$ & $-13[-26.52,0.52]$ \\
\hline Subtotal $\star \star \star ~$ & 365 & & 160 & & & $100 \%$ & $-3.27[-12.03,5.5]$ \\
\hline \multicolumn{8}{|c|}{ Heterogeneity: $\mathrm{Tau}^{2}=0 ; \mathrm{Chi}^{2}=5.94, \mathrm{df}=3(\mathrm{P}=0.11) ; \mathrm{I}^{2}=49.47 \%$} \\
\hline \multicolumn{3}{|c|}{ Test for overall effect: $Z=0.73(P=0.47)$} & & & & & \\
\hline
\end{tabular}

Analysis 1.11. Comparison 1 Statins versus control, Outcome 11 Adverse events.

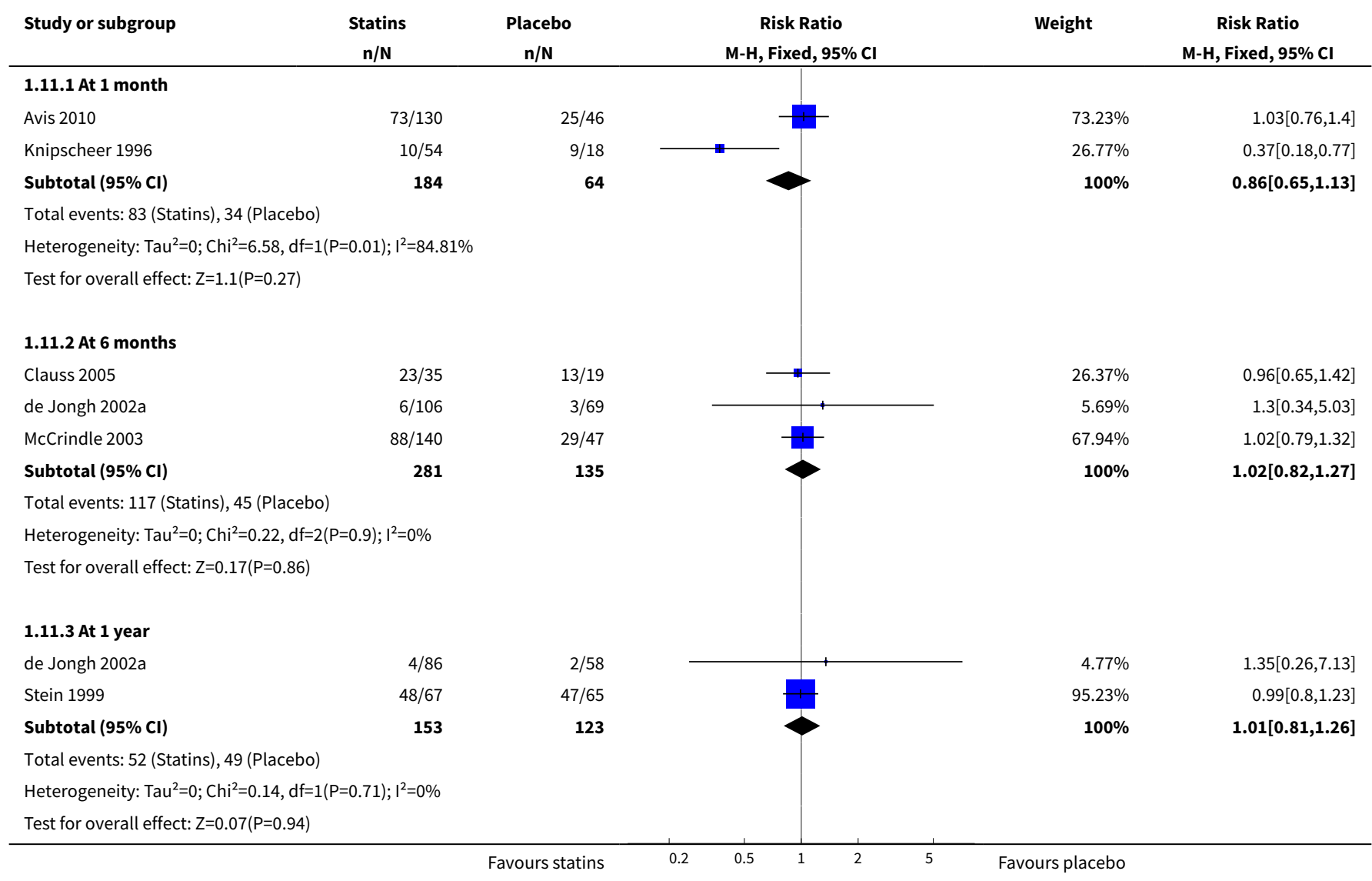

\section{APPENDICES}

Appendix 1. Search strategies - trials registers

Registry Search terms

Statins for children with familial hypercholesterolemia (Review) 
(Continued)

\section{WHO ICTRP Search terms: statin AND familial hypercholesterolemia}

Study type: interventional studies

Condition: clinical trials in children

Phase: any

\begin{tabular}{l} 
ClinicalTrials.gov \\
Intervention: statin \\
Age: Child \\
Phase: any \\
\hline
\end{tabular}

WHAT'S NEW

\begin{tabular}{lll}
\hline Date & Event & Description \\
\hline 12 March 2020 & Amended & $\begin{array}{l}\text { An error in the consistency of the reporting of the quality of the } \\
\text { evidence in relation to low-density lipoprotein cholesterol con- } \\
\text { centration has been corrected. }\end{array}$ \\
\hline
\end{tabular}

\section{H I S T O R Y}

Protocol first published: Issue 1, 2007

Review first published: Issue 7, 2010

\begin{tabular}{lll}
\hline Date & Event & Description \\
\hline 4 November 2019 & New search has been performed & $\begin{array}{l}\text { A search of the Cochrane Cystic Fibrosis and Genetic Disorders } \\
\text { Group's Inborn Errors of Metabolism Trials Register identified 71 } \\
\text { references, of these, one reference was evaluated for eligibility } \\
\text { and was excluded. }\end{array}$ \\
& & \\
\hline
\end{tabular}

\begin{tabular}{lll}
\hline 4 November 2019 & $\begin{array}{l}\text { New citation required but conclusions } \\
\text { have not changed }\end{array}$ & $\begin{array}{l}\text { Minor changes have been made throughout the review. There } \\
\text { have been no changes to the conclusions. }\end{array}$ \\
\hline 20 November 2017 & Amended & $\begin{array}{l}\text { Amended incorrect reporting of blinding assessment in the ab- } \\
\text { stract. }\end{array}$ \\
\hline 28 June 2017 & $\begin{array}{l}\text { New citation required but conclusions } \\
\text { have not changed }\end{array}$ & $\begin{array}{l}\text { One new trial (107 participants) has been included in this update } \\
\text { of the review (Braaskamp 2015a). However, this did not lead to } \\
\text { any major changes in the conclusions of the review. }\end{array}$ \\
\hline New search has been performed & $\begin{array}{l}\text { One new trial has been included in this update of the review } \\
\text { (Braaskamp 2015a). However, this did not lead to any major } \\
\text { changes in the conclusions of the review. }\end{array}$ \\
\hline 3 July 2014 2017 & New search has been performed & $\begin{array}{l}\text { One new trial has been included in the review update (Avis 2010). } \\
\text { We are now using the definitions of statin-related myopathy pro- } \\
\text { vided by the U.S. Food and Drug Administration which relate to }\end{array}$ \\
\hline
\end{tabular}




\begin{tabular}{|c|c|c|}
\hline Date & Event & Description \\
\hline & & $\begin{array}{l}\text { two clinical entities are used: (1) myopathy (creatine kinase over } \\
10 \text { x ULN); and (2) rhabdomyolysis (creatine kinase over } 50 \text { ULN } \\
\text { and evidence of organ damage) (Joy 2009). } \\
\text { One sub-study of the de Jongh } 2002 \text { study (de Jongh 2002b), pre- } \\
\text { viously listed as a separate included study, has been correctly } \\
\text { linked under the de Jongh } 2002 \text { included study (de Jongh 2002a). }\end{array}$ \\
\hline 3 July 2014 & $\begin{array}{l}\text { New citation required but conclusions } \\
\text { have not changed }\end{array}$ & $\begin{array}{l}\text { One new trial has been included in this update of the review (Avis } \\
2010) . \text { However, this did not lead to any major changes in the } \\
\text { conclusions of the review. }\end{array}$ \\
\hline 20 October 2008 & Amended & Converted to new review format. \\
\hline 15 October 2007 & $\begin{array}{l}\text { New citation required and conclusions } \\
\text { have changed }\end{array}$ & Substantive amendment \\
\hline
\end{tabular}

\section{CONTRIBUTIONS OF AUTHORS}

Conceiving the review (AV02, PK01, SH01)

Designing the review (AV02, JK01, PK01, SH01)

Coordinating the review (AV02)

Data collection for the review (AV02, JK01)

Developing search strategy (JK01)

Undertaking searches (AV02, JK01)

Screening search results (AV02, JK01)

Organising retrieval of papers (AV02, JK01)

Screening retrieved papers against inclusion criteria (AV02, JK01)

Appraising quality of papers (AV02, JK01, PK01)

Abstracting data from papers (AV02, PK01)

Providing additional data about papers (JK01,SH01)

Data management for the review (JK01)

Entering data into RevMan (JK01)

Analysis of data (JK01)

Interpretation of data (AV02, JK01, TS01, PK01, SH01, AW, ST)

Providing a methodological perspective (JK01)

Providing a clinical perspective (AV02, G01, TS01, PK01, SH01, AW, ED,ST)

Providing a policy perspective (TS01, PK01, SH01)

Providing a consumer perspective

Writing the review (AV02, JK01, PK01)

Providing general advice on the review (TS01, PK01, SH01, AW, ST)

Securing funding for the review (AV02, JK01, PK01)

\section{DECLARATIONS OF INTEREST}

Alpo Vuorio: none known.

Jaana Kuoppala: none known.

Petri Kovanen: I have been paid for consultancy by Raisio and Unilever, and for lectures by Raisio, Unilever, Amgen, and Aegerion.

Steve Humphries: The Children' UK Pediatric Register has been funded 2014-2016 by the BHF and 2016-2018 by a grant from the International Atherosclerosis Society.

Serena Tonstad: none known.

Albert Wiegman: none known.

Euridiki Drogari: none known.

Uma Ramaswami: none known. 


\section{SOURCES OF SUPPORT}

\section{Internal sources}

- No sources of support supplied

\section{External sources}

- The Finnish Office for Health Technology Assessment, National Research and Development Centre for Welfare and Health, Finland.

The Finnish Office for Health Technology Assessment, National Research and Development Centre for Welfare and Health has financially supported the preparation of this review.

- National Institute for Health Research, UK.

This systematic review was supported by the National Institute for Health Research, via Cochrane Infrastructure funding to the Cochrane Cystic Fibrosis and Genetic Disorders Group.

\section{DIFFERENCES BETWEEN PROTOCOL AND REVIEW}

We changed the age limit of participants from 17 years to 18 years. During the study selection, it became apparent several centers use 18 years as the cut off point for pediatric to adult services and we feel excluding these data would introduce a bigger bias to the review than changing the inclusion criteria.

Definitions of statin-related myopathy is now following U.S. Food and Drug Administration definitions and only two clinical entities are used: 1) myopathy (creatine kinase over $10 \mathrm{x}$ upper limit of normal (ULN)) and rhabdomyolysis (creatine kinase over 50 ULN and evidence of organ damage) (Joy 2009).

We grouped outcome data into those measured at at six months ( \pm two weeks), at one year ( \pm four weeks) and at two years.

\section{N DEX TERMS}

\section{Medical Subject Headings (MeSH)}

*Heterozygote; Alanine Transaminase [blood]; Aspartate Aminotransferases [blood]; Brachial Artery [drug effects]; Carotid IntimaMedia Thickness; Cholesterol, LDL [blood]; Creatine Kinase [blood]; Hydroxymethylglutaryl-CoA Reductase Inhibitors [adverse effects] [*therapeutic use]; Hyperlipoproteinemia Type II [blood] [ ${ }^{\star}$ drug therapy] [genetics]; Puberty [drug effects]; Randomized Controlled Trials as Topic; Vasodilation [drug effects]

\section{MeSH check words}

Adolescent; Child; Child, Preschool; Female; Humans; Male 